\title{
LAW AND BORDER: ADDRESSING SECURITY THREATS AT THE UKRAINIAN BORDER
}

\section{Collective monograph}

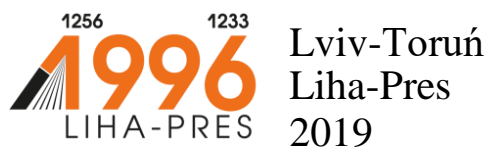




\section{Reviewers:}

Prof. dr hab. Sabina Grabowska, Uniwersytet Rzeszowski / University of Rzeszow (Republic of Poland);

Prof. $d r$ hab. Joanna Marszatek-Kawa, Uniwersytet Mikołaja Kopernika $w$ Toruniu / Nicolaus Copernicus University (Republic of Poland).

\section{Edited by prof. Natalya Orlovska}

Law and Border: Addressing Security Threats at the Ukrainian Border : collective monograph / N. Orlovska, S. Filippov, V. Kukhar, I. Hloviuk, V. Polovnikov, I. Kushnir, P. Volynets. - Lviv-Toruń : Liha-Pres, 2019. - $132 \mathrm{p}$.

ISBN 978-966-397-159-9

Liha-Pres is an international publishing house which belongs to the category "C" according to the classification of Research School for Socio-Economic and Natural Sciences of the Environment (SENSE) [isn: 3943, 1705, 1704, 1703, 1702, 1701; prefixMetCode: 978966397]. Official website www.sense.nl. 


\section{CONTENTS}

ILLEGAL MIGRATION: CRIMINAL LEGAL SURVEY

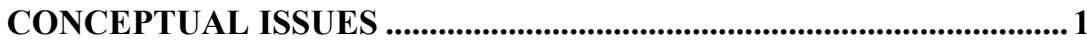

Natalya Orlovska

CHARACTERISTIC FEATURES OF COMBATING

CROSS-BORDER CRIME ON THE SEA ROUTES

AND IN THE AIRSPACE 18

Stanislav Filippov

COORDINATION OF ACTIVITY OF BODIES

AND SERVICES PERFORMING DIFFERENT TYPES

OF CONTROL AT THE STATE BORDER 36

Valerii Kukhar

CRIMINAL PROCEEDINGS REGARDING ENFORCED

DISAPEARANCE IN UKRAINE: ISSUES OF NORMATIVE

REGULATION.

Iryna Hloviuk

ADMINISTRATIVE AND LEGAL REGULATION PECULIARITIES OF THE MANAGING ACTIVITIES OF THE UKRAINIAN

STATE BORDER GUARD BODIES (UNITS) CHIEFS.

Vadym Polovnikov

TOPICAL DIRECTIONS FOR IMPROVEMENT

OF INFORMATION RELATIONS IN ACTIVITIES

OF THE STATE BORDER GUARD SERVICE OF UKRAINE

Iryna Kushnir

CERTAIN ASPECTS OF UKRAINIAN BORDER SECURITY

MECHANISM FUNCTIONING 109

Pavlo Volynets 
DOI https://doi.org/10.36059/978-966-397-159-9/1-17

\section{ILLEGAL MIGRATION: CRIMINAL LEGAL SURVEY CONCEPTUAL ISSUES}

\section{Natalya Orlovska}

\section{INTRODUCTION}

Migration issues have been always actualized for any of countries. In particular, during alone 2018: nearly 28 million people were forced to migrate due to military conflicts (10.8 million) and natural disasters (17.2 million $)^{1}$. EU countries and USA are mostly faced with external migration challenges - exactly in corresponding readout the social contradictions and political collisions become more evident.

The US example demonstrates haw precisely various migration issues are becoming a significant factor of current agenda. In this context especial attention is paid to crimes committed by migrants.

Many immigration advocates argue that immigrants have much lower crime rates than natives. The federal government does track the citizenship of those it convicts. Data from the U.S. Sentencing Commission shows that of those convicted of federal crimes between 2011 and 2016, 44.2\% were not U.S. citizens $-21.4 \%$, if immigration crimes are excluded. Non-citizens are $8.4 \%$ of the adult population. Of this $8.4 \%$ about $4 \%$ are illegal immigrants $^{2}$. Pursuant to Criminal history category and citizenship of offenders sentenced under immigration guidelines for 2017:non-U.S. citizens have committed 26799 crimes out of 66873 cases $^{3}$. In continuation of this: in $201826 \%$ of federal prisoners were aliens.

Migrant considered criminality trends have prompted a professional discussion concerning criminal justice system organization. Within those debates it was even suggested that the state and local prosecutors who have set up two systems of justice - a harsher one for citizens and a more lenient

1 Key Global Migration Figures, 2017 - 2019. URL: https://migrationdataportal.org/ sites/default/files/2019-08/key-global-migration-figures.pdf

${ }^{2}$ Camarota S.A. (2018) Non-Citizens Committed a Disproportionate Share of Federal Crimes, 2011-16. URL: https://cis.org/Camarota/NonCitizens-Committed-DisproportionateShare-Federal-Crimes-201116

${ }^{3}$ Immigration Data from the U.S. Sentencing Commission "Interactive Sourcebook of Federal Sentencing Statistics". URL: https://isb.ussc.gov/api/repos/:USSC:table_xx.xcdf/ generatedContent?table_num=Table49 
one for aliens - push ideas in order to "protect" alien criminals from what they view as the "excesses" of the administration's immigration policies ${ }^{4}$.

However, despite the fact that developed countries are the ultimate destination for migrants, the threats of illegal migration are more appreciable for developing countries because of they actually appear themselves as a certain temporary destination or transit element as a component of global migration processes. Therefore, these countries` costs share associated to this negative phenomenon is disproportionately increased ${ }^{5}$.That is why the problem of illegal migration, including especially its criminal legal aspect, is extremely important for Ukraine.

Criminal legal survey of illegal migration covers the whole problematic sphere of socially dangerous acts criminalization, punishments and other law measures that may be imposed for such acts committing. However, the analysis of contemporary criminal issues cannot be considered in isolation from the wider context.

\section{The initial provisions for illegal migration criminal legal survey}

The analysis of illegal migration in the context of criminal law requires definiteness relatively corresponding terminology. During recent years the international community has been moving away from using the term «illegal migration» simultaneously suggesting it to replace with «irregular migration» term.

International Organization for Migration (IOM) defines irregular migration as movement of persons that takes place outside the laws, regulations, or international agreements governing the entry into or exit from the State of origin, transit or destination ${ }^{6}$. The opposite concept is about regular (so-called, orderly) migration which is defined as the movement of a person from his/her habitual residence to a new place of residence, being a law abiding subject of the laws and departure regulation rules of country of origin and transit through/or entering on the territory of destination or transit country ${ }^{7}$.

\footnotetext{
${ }^{4}$ Arthur A.R. (2019) Are Criminal Aliens Above the Law? URL: https://cis.org/Arthur/ Are-Criminal-Aliens-Above-Law

${ }^{5}$ Ukrainske suspilstvo: mihratsiinyi vymir : natsionalna dopovid (2018) [Ukrainian society: migration survey : national report] Kyiv: Instytut demohrafii ta sotsialnykh doslidzhen im. M. V. Ptukhy NAN Ukrainy. P.137-138.

${ }^{6}$ Irregular migration URL:https://www.iom.int/key-migration-terms

${ }^{7}$ Mizhnarodna terminolohiia u sferi mihratsii: ukrainsko-anhliiskyi tlumachnyi slovnyk [International terminology in migration sphere: Ukrainian-English dictionary] Kyiv: BLANKPRES, 2015. P.8, 15.
} 
These terminological changes could be explained by the ontological negative sense of the «illegal migration» term, since it carries a criminal connotation and is seen as degrading to the migrant`s dignity ${ }^{8}$. However, the «illegal migration» term continues to be used in international circulation at the same time.

From our point of view the issue concerning extremely negative meaning for «illegal migration» definition is artificial by itself. In particular, the IOM emphasizes the unlawfulness of a person's actions to change his or her location: while it is unclear what practical importance an emphasis on adjective «irregular» or «illegal» has had.

What is about stigmatization of migrants as such then trying to solve or soften this problem through terminology changing is more like a departure from reality. Much more for migrants' dignity protection can be done by a well-considered state migration policy oriented on social integration.

Having taken into research consideration illegal migration as whole phenomenon there is absolutely naturally that, in addition to the national statistical data the practices of law enforcement and border guard institutions of the neighboring states, as well as the practices of interstate police forces are widely used. For example, there is possible to use various analytical data from the FRONTEX and FRAN (FRONTEX Risk Analysis Network) Annual Risk Analysis which assumes CIRAM (Common Integrated Risk Analysis Model) methodological approaches'.

One of the five main illegal migration routes is passed through the territory of Ukraine - the Central European route running through the Russian Federation, Ukraine, Poland and Slovakia to the countries of Western Europe ${ }^{10}$. For instance, Central Asian labour migrants try all possible ways to enter the Russian Federation or find other opportunities using facilitators for seeking asylum in the EU. If these migrants do not find a job in Kazakhstan or in Turkey, they use the Balkan, Ukraine and Belarus routes to reach the EU. Regional facilitators are typical for the eastern EU

${ }^{8}$ Mizhnarodna terminolohiia u sferi mihratsii: ukrainsko-anhliiskyi tlumachnyi slovnyk [International terminology in migration sphere: Ukrainian-English dictionary] Kyiv: BLANKPRES, 2015. P.15.

${ }^{9}$ Filippov S.O. (2019) Protydiia transkordonnii zlochynnosti: hlobalnyi kontekst $i$ realii Ukrainy: monohrafiia [Countering cross-border crime: the global context and realities of Ukraine] Odesa: Feniks. P.21.

10 Stratehiia intehrovanoho upravlinnia kordonamy na period do 2025 roku [2025 Integrated Border Management Strategy]: Approved by the Cabinet of Ministers of Ukraine on July 24, 2019 № 687-p. URL: https://zakon.rada.gov.ua/laws/show/687-2019-\%D1\%80 
border sections. Russian citizens were ranking first, followed by Belarusians and Ukrainians ${ }^{11}$.

FRONTEX data provides information on the irregular border crossing (IBC) of eastern border zone of the EU (2009-2017) that indicates the positive trends in Ukraine, which last worsened in $2016^{12}$, when Ukraine reported the highest number of detections followed by Latvia and Hungary.

Herewith 324 cases of illegal border-crossing were detected. More than three-quarters of detections took place at Ukrainian borders, involving mostly regional migrants, i.e. Ukrainians and Moldovans. Non-regional migrants (mostly citizens of Vietnam, Turkey and Iran) were detected in very low numbers ${ }^{13}$.

Thus, there are no significant difficulties when considering Ukraine as a country of origin and transit of illegal migrants. According to FRONTEX data only $0.2 \%$ of illegal migrants enter the EU collectively from the territories of Ukraine and Belarus. Consequently, the level of illegal migration of third-country nationals threat through the territory of Ukraine remains low ${ }^{14}$.

This gives for European countries the opportunity to redistribute resources and strengthen the counteraction to so-called secondary migration when migrants from non-EU countries move illegally between EU countries.

As significant factor in positive results achieving has became the active role of law enforcement institutions of Ukraine, first of all - the activity of the State Border Guard Service of Ukraine (SBGSU). Thus, in cases of state border illegal crossing by the efforts of SBGSU were detained: in 2016 1040 persons (88\% of them when attempting to leave Ukraine); in 2017 886 people (82\%); in $2018-1130$ (78\%); during 9 months in $2019-$ 830 people. Herewith for 9 months in 2019 being comparing to the same period in 2018 the number of foreigner refusals - potential illegal migrants -

\footnotetext{
${ }^{11}$ Migrant Smuggling Data and Research: A global review of the emerging evidence base, Volume 2 / edited by A. Triandafyllidou and M.L. McAuliffe; International Organization for Migration, Geneva, 2014. P.80

${ }^{12}$ Migrant Smuggling Data and Research: A global review of the emerging evidence base, Volume 2 / edited by A. Triandafyllidou and M.L. McAuliffe; International Organization for Migration, Geneva, 2014. P.76

${ }^{13}$ Eastern Partnership Risk Analysis Network Quarterly; Quarter 2. April-June 2016, Frontex. Warsaw. P.6, 7

${ }^{14}$ Mihratsiinyi profil Ukrainy za 2017 rik (2018) [Ukraine`s Migration Profile for 2017]. State Migration Service of Ukraine. URL: https://dmsu.gov.ua/assets/files/mig_profil/ migprofil_2017.pdf 
has increased in 1.5 times $^{15}$. The State Migration Service of Ukraine(SMSU) activity results in illegal migrants in the territory of Ukraine detecting can be recognized as significant ones: in 2016 there were 6390 persons; in 2017 9 678; in 2018 - 11 194; for 6 months in $2019-5780^{16}$. During 2018 alone: 249 groups of 1278 illegal migrants were identified by the National Police together with the SMSU and SBGSU ${ }^{17}$. At the same time, a large part of illegal migrants detection falls on the main educational regions of Ukraine where most foreigners traditionally live ${ }^{18}$.

This indicates the effectiveness increasing for prevention activities aimed on detecting and ending the offenses related to illegal migration.

But there is an increase in the number of migrants on legal entry channels, who (relying on the support of the Diasporas) formally try to get into Ukraine in order to remain here illegally or subsequently illegally enter the territory of the EU. Basically this confirms the tendency for so-called "delayed transit" when migrants formally legally enter the country (Ukraine) with an intention for further traveling abroad including through illegal means. However, the length of their staying in Ukraine does not have a fundamental importance.

In no case can it be argued that all or the vast majority of migrants who use legal routes to enter Ukraine are prone to commit crimes, aggravate the criminal situation and so on. However, in the case of considering Ukraine as a transit territory then migrants (sooner or later) become involved in illegal relations concerning to document forgery, illegal migration organization, human trafficking, smuggling etc.

Characteristic of migrants is the formation of Diasporas which role is ambivalent: on the one hand, in the Diasporas concrete migrant feels certain support and security, on the other - the Diaspora if not makes it impossible but significantly impedes the integration of migrants into current staying society. Although, viewing on the ultimate goal, the migrant is not very interested in such integration, but exactly this aspect enhances his

${ }^{15}$ Rezultaty operatyvno-sluzhbovoi diialnosti Derzhavnoi prykordonnoi sluzhby Ukrainy [The results of the operational and service activities of the State Border Guard Service of Ukraine]. URL: https://dpsu.gov.ua/ua/activity/ohorona-kordonu

${ }^{16}$ Rezultaty diialnosti Derzhavnoi mihratsiinoi sluzhby Ukrainy [The results of the activities of the State Migration Service of Ukraine]. URL: https://dmsu.gov.ua/diyalnist/ statistichni-dani/statistika-z-osnovnoj-diyalnosti.html

${ }^{17}$ U Natspolitsii tryvaie zahalnoderzhavna spetsoperatsiia «Mihrant» [National Migrant Special Operations Continues at National Police] URL: https://www.kmu.gov.ua/ua/news/unacpoliciyi-trivaye-zagalnoderzhavna-specoperaciya-migrant

18 Ukrainske suspilstvo: mihratsiinyi vymir : natsionalna dopovid (2018) [Ukrainian society: migration survey : national report] Kyiv: Instytut demohrafii ta sotsialnykh doslidzhen im. M. V. Ptukhy NAN Ukrainy. P.14, 333. 
victimization. Actually, it is highly likely that such persons are able to become the victims of criminal offenses including fraud by so-called "traffickers" among which are available illegal migrants themselves.

Given this the inclusion of illegal migration studies into the more general security discourse and the migration dimension of national security separation along with economic, social, environmental aspects, etc. should be supported.

At the same time, the confrontation between the interests of the individual and the society is inappropriate, and national and migrant security must be united in order to reaching a common goal - to reduce the volumes of illegal migration through transferring their flows into the legal sphere ${ }^{19}$.

Precisely in the security context the issues of state migration policy are considered today - among its legal instruments the prominent position belongs to criminal legal influence.

\section{The place and role of criminal legal influence in the state migration policy of Ukraine}

The state migration policy of Ukraine development has been strategically formalized after the Strategy of the state migration policy of Ukraine for the period up to 2025 adoption. Such program of actions reflected the modern European approaches in this sphere. In particular, the approaches that define and shape migration policy include the expulsion of illegal migrants and the legal status adjustment for those persons who cannot be excluded according to humanitarian grounds. At the same time the law enforcement approach retains its importance and plays a leading role. It is aimed at strengthening migration control to identify and neutralize organized structures in the sphere of illegal migration and trafficking in human beings organizing.

Thus, Ukraine demonstrates progress in the framework of pan-European migration policy bringing the issues of non-repressive methods of migration processes regulation to the fore. With regard to combating illegal migration this indicates an attempt to respond concerning challenges and threats by outstripping offenses in migration sphere.

However, establishing responsibility for offenses in the migration field remains in the focus of prevention activity. This is explicitly stated in the Strategy of the State Migration Policy of Ukraine for the period up to 2025 as a direction of the mentioned policy determining - strengthening of responsibility for offenses in the migration field.

19 Ukrainske suspilstvo: mihratsiinyi vymir : natsionalna dopovid (2018) [Ukrainian society: migration survey : national report] Kyiv: Instytut demohrafii ta sotsialnykh doslidzhen im. M. V. Ptukhy NAN Ukrainy. P. 136, 138. 
Pay attention that there is no direct designation precisely on criminal responsibility installation establishing. And speaking about national legal system then administrative responsibility is established first of all for the offenses in the migration sphere. In particular, it is about:

delicts of illegal migrants (for example, violation of staying in Ukraine and transit through the territory of Ukraine rules by foreigners and stateless persons; illegal crossing or attempting to cross illegally the state border of Ukraine);

delicts of Ukrainian citizens aimed on illegal migrants facilitating (failure to take measures to ensure timely registration of foreigners and stateless persons; violation of the rules of foreigners and stateless persons housing and vehicles providing, and other services facilitating provision; foreigners and stateless persons illegal transfer through the territory of Ukraine).

However, the most socially dangerous acts are criminalized, in particular, viewing on international commitments concluded by Ukraine in the sphere of illegal migration as a type of transnational crime preventing. The main document in this area is Protocol against the Smuggling of Migrants by Land, Sea and Air, supplementing the United Nations Convention against Transnational Organized Crime to which Ukraine has been a party since $2004^{20}$.

According to international standards Ukraine has found as out of criminal legal to smuggle persons across the state border. In addition, criminal liability for related acts including the creation of a criminal organization, forgery of documents, etc., has been established.

According to Art. 6 of the Protocol against the Smuggling of Migrants by Land, Sea and Air: the legislative measures as may be necessary to establish as aggravating circumstances to the offences established in accordance the lives or safety of the migrants concerned; or entail inhuman or degrading treatment including for such migrants exploitation - have to be adopted by State. These obligations were fulfilled by Ukraine in establishing criminal liability for more serious cases of persons transfer across the state border.

Therefore, it cannot be argued that the importance of criminal legal influence in state migration policy is exaggerated in Ukraine. It seems that the state uses criminal instruments fairly moderately - only in cases when other legal remedies cannot solve the problem of illegal migration preventing.

${ }^{20}$ United Nations Convention against Transnational Organized Crime and the Protocols Thereto / UNODC. Vienna URL: https://www.unodc.org/documents/middleeastandnorthafrica/ organised-crime/united_nations_convention_against_transnational_organized_crime_and_the_ protocols_thereto.pdf 
As noted above, developing countries are more affected by illegal migration than developed countries. This raises the question about the expediency of establish criminal liability or punishment increasing for certain socially dangerous acts.

It seems that the point-to-point application of criminal legal influence in the context of state migration policy also appears to be due to the fact that the costs of illegal migration combating are not only direct costs but also include expenses for reputational issues (protection of human rights and freedoms, organization of law enforcement agencies and judicial system, etc.).

Against this background it should be recognized that criminal legal influence is the most costly part of illegal migration preventing activity. That is why the requirements to the quality of criminal law and enforcement in this part are so important.

\section{The issues of criminal influence for crimes related to illegal migration}

The XIII United Nations Congress on Crime Prevention and Criminal Justice devoted to crime issues particularly emphasized the danger of transnational crime various forms that adversely affect the sustainable development of society. Among the most socially dangerous manifestations affecting the interests of many countries is the illegal import (smuggling) of migrants ${ }^{21}$.

However, this position mainly reflects the situation in the recipient countries: illegal export and transit of migrants are no less as the problems. The manifestations of illegal migration have become the result of globalization processes when criminal activity was distributed in the world, has been formatted a "criminal map" which illustrates the regularities of the criminal processes interconnection. In addition to the global survey the regional is also important one. In the European context, in particular, this is manifested in the unilateral direction of illegal migration routes (from East to West).

The criminal survey of illegal migration correlates with the criminological nature of socially dangerous acts in this sphere: on the one hand, it is a relatively independent group of crimes, on the other - it is a background phenomenon that aggravates the criminal situation in the country.

Investigation of the criminological nature of these crimes allows us to distinguish the features of migration crimes that are embodied in criminal law. These features include:

${ }^{21}$ XIII United Nations Congress on Crime Prevention and Criminal Justice (Doha, 12-19 April 2015) URL: http://www.un.org/ru/events/crimecongress2015 
1. Transnationality / transborderness of separate action and socially dangerous activities by and large.

Article 3 of the United Nations Convention against Transnational Organized Crime gives off 4 features of a transnational crime, the presence of at least one of which provides grounds to classify the act as transnational one:

it is committed in more than one State;

it is committed in one State but a substantial part of its preparation, planning, direction or control takes place in another State;

it is committed in one State but involves an organized criminal group that engages in criminal activities in more than one State;

it is committed in one State but has substantial effects in another State ${ }^{22}$.

A separate type of transnational crimes is transborder criminal activity which is directly related to the state border crossing. It is obvious that manifestations of illegal migration in the criminal legal survey are crossborder crimes since in the process of their committing there is a physical movement of persons across the state border.

However, criminal law does not always clearly identify the signs of a transnational / transborder crime. It seems that in determining such a crime there is supposedly to proceed not only from the normative definitions but also from its objective characteristics.

Thus, if the objective side of a crime involves actions related to moving across a state border then such crime can be considered as transnational / transborder one.

Therefore, criminalized manifestations in the sphere of illegal migration are transnational / transborder acts, and basically - illegal migration is an amplitutious transnational negative phenomenon affecting the interests of more than one state.

Exactly as a type of transborder crime the illegal migration is closely linked to human trafficking, smuggling of weapons, ammunition, explosives and drugs, transnational corruption and international terrorism.

2. Economic nature which determines the shadow business kind formation in the sphere of illegal migration.

At the current stage the transnational / transborder crime is economic in its nature. This thesis is obvious when considering the crimes related to the movement of goods / items / information. In such a case the main factor that

${ }^{22}$ United Nations Convention against Transnational Organized Crime and the Protocols Thereto / UNODC. Vienna URL: https://www.unodc.org/documents/middleeastandnorthafrica/ organised-crime/united_nations_convention_against_transnational_organized_crime_and_ the_protocols_thereto.pdf 
determines the development of criminal activity is the different profitability of economic transactions in the territories on both sides of the state border: by using the economic situation in these territories criminals receive a financial gain. However, when it comes to crimes related to illegal migration then it is important to recognize that there are more complex economic levers.

Crime activity in illegal migration sphere is a shadow business with a complex structure consisted of:

economic activity related to the transit of migrants across borders; concerning its profitability the involvement of the around-the-border residents in such displacement processes indicates (for example, according to the press service of the Security Service of Ukraine in Lviv region, in April 2019 a citizen of Ukraine - a migrant smuggler was detained upon receipt of $\$ 1$ thousand);

economic activity related to the exploitation of illegal migrants in Ukraine; in such cases the citizens of Ukraine are trying to use the work of illegal migrants who are attempting to earn costs for further cross-border crossing. In particular, the story of 28 migrants from Vietnam revealed in October 2018 in the Glevakha village, Kyiv region, where they were held in slavery for three months ${ }^{23}$.

Accumulation of shadow income from illegal migration plays an ambivalent role:

on the one hand, significant financial resources in this sphere allow economic agents to influence on the socio-political situation (at least in the border regions). In particular, law enforcement agencies may be restricted in carrying out certain preventive measures because of the resistance of the population interested in the shadow business;

on the other side, these revenues become a vulnerable place in criminal schemes because their disclosure makes it possible to identify not only individual carriers, but whole criminal groups as well. Thus, the XIII United Nations Congress on Crime Prevention and Criminal Justice emphasized that combating the illegal importation of migrants (smuggling of migrants) involves conducting financial investigations to track the revenue of criminal groups.

\section{Organized nature.}

Because of illegal migration presents itself a shadow transnational / transborder business then there must be recognized that it can exist only as

${ }^{23}$ Erman G. (2018) Skil'ky nelehaliv khoche potrapyty do ES z Ukrayiny i shcho z nymy stayet'sya [How many illegals want to get to the EU from Ukraine and what happens to them] URL: https://www.bbc.com/ukrainian/features-50220375 
organized activity since organized nature is inherently considered for business practice. However, in the context of crime it is a criminal activity form - organized crime as an activity of persistent criminal groups focused on obtaining the maximum income spending the minimum of time. The "organization" in relation to illegal migration actually reflects the unity of the shadow business and the criminal groups involved in it.

In the context of traditional view the criminal groups are organized groups and criminal organizations. However, the organizational level of criminals involved into smuggling migrants processes can vary enough significantly. In this sphere there are not only mafia type groups of a with a hierarchical structure, but also less rigidly built crime networks each of which plays a certain role at different stages of the migrants smuggling. Basically according to experts` opinion, than further then more important becomes the networks role that arises and cooperates with each other based on market forces in an effort to make a profit ${ }^{24}$.

Thus, the economic actors involved in the shadow business of illegal migrants displacing are very diverse ones. At one end of the scale are the (irregular) migration agents, who maybe legitimate travel or migration agents providing lawful services to travellers/migrants, with perhaps occasional assistance to those seeking to travel irregularly (such as fraudulent documents, contacts and information/advice). At the other end of the spectrum are the "apex" smugglers/traffickers, who oversee sophisticated transnational criminal syndicates and networks that deal with large-scale operations, often involving different types of smuggling and/or trafficking ${ }^{25}$.

However, it is worth mentioning about even more threatening situation the massive involvement of the border regions residents into such activity with amorphous groups without a defined structure formation.

Thus, illegal migration is a kind of shadow business and a component of transnational / transborder organized crime. At the same time it plays a role of a favorable basis for the deterioration of the criminal situation in the country, the "entering" into the territory of Ukraine of transnational criminal groups and so on. In this context illegal migration is a purely negative phenomenon the existence of which requires the prevention of mostly compulsory measures - by criminal legal ones.

24 Mezhdunarodnaya platforma deystviy $v$ tselyakh vypolneniya Protokola protiv nezakonnogo vvoza migrantov (2012) [International Platform for the Implementation of the Protocol against the Smuggling of Migrants] / UNODC. Vena. P.3, 6.

${ }^{25}$ Facilitating migration and fulfilling rights - to reduce smuggling of migrants and prevent trafficking in persons. 4-5 September 2017, Vienna. URL: https://refugeesmigrants.un.org/sites/ default/ files/ts5_gaatw.pdf 
First of all, it should be noted that the Criminal Code of Ukraine does not have definitions or signs of transnational /transborder crime. However, both the textual and contextual criminal legislation prescribe responsibility for such crimes including those of them related to illegal migration.

Thus, in the Common part of the Criminal Code of Ukraine there are provisions on the place of crime committing (Article 6). They regulate the rules of the criminal legislation of Ukraine application for crimes the process of which committing involves at least two states - respectively, such acts fall under the jurisdiction of such states. Other provisions of the Common Part refer, more likely, to procedural aspects for other states sentences recognition or the offenders extradition.

For this reason the illegal migration related crimes fall under the jurisdiction of Ukraine if they were initiated, continued, finished or terminated in the territory of Ukraine. Accordingly, at any stage of the intent realization a person who illegally moves people across the border or crosses a state border in violation of a criminal legal prohibition may be held criminally liable.

In the Special Part of the Criminal Code of Ukraine the acts related to illegal migration are not limited to the crime of "Illegal Transfer of Persons across the State Border of Ukraine". Let us pay attention to the act that was criminalized in connection with the Russian aggression against Ukraine "Illegal Crossing of the State Border of Ukraine". In addition, Article 149 provides for criminal liability for human traffic. Although the acts that constitute the structure of human traffic may also be committed on the territory of Ukraine the practice testifies to the predominantly transborder nature of this crime.

Therefore, criminal legal manifestations of illegal migration are covered by Articles 332 "Illegal Transfer of Persons across the State Border of Ukraine", 332-2 "Illegal Crossing of the State Border of Ukraine", 149 "Human Traffic".

What is the difference between the illegal transfer of persons across the state border and the illegal crossing of the state border? It seems that the following conclusions can be drawn:

the criminal liability establishing for the illegal transfer of persons across the state border is the embodiment of Ukraine's international obligations in accordance to United Nations Convention against Transnational Organized Crime and the Protocol against the Smuggling of Migrants by Land, Sea and Air; criminal responsibility for illegal crossing of the state border is a means of national security of Ukraine protection in the conditions of armed aggression; 
contextually criminal-punishable transfer of persons across the state border is the import and export of illegal migrants to / from the territory of Ukraine; out of criminal law crossing of the state border is exactly entry into Ukraine;

the subject of the illegal transfer of persons across the state border is the person who transports, organizes or facilitates the illegal migrant to enter Ukraine or another state, that is, the subject of this crime is not the illegal migrant himself; the subject of the illegal crossing of the state border is the migrant himself;

the subject of illegal transfer of persons across the state border in most cases pursues mercenary motives (although an indication of a moneymaking motive is presented only in part 3 of Article 322); the subject of illegal crossing of the state border has already had problems with the law (the person who is forbidden to enter the territory of Ukraine), or is trying to cause damage to the national security of Ukraine.

Thus, the vision of illegal migration as a type of transnational / transborder shadow business which is characterized by organized forms of activity does not cover the illegal crossing of the state border, because this activity is predominantly political by nature. However, it is seen that in the commission of this crime the person forbidden to enter the territory of Ukraine does not exclude the attempt in the future to illegally leave the territory of Ukraine in the western direction through intermediaries. That is, the subject of illegal crossing of the state border "turns" into the person involved in illegal crossing across the state border.

With regard to in human traffic this crime (in the case of the victim being moved across the state border) is a part of the criminal survey of illegal migration. What is concerning the facts of human trafficking registered in Ukraine then more than $75 \%$ of them are transborder acts.

Legislation on criminal liability for human traffic meets international standards in this sphere. In particular, the punishment for committing a crime against a child, in the case of violence, by organized crime structures, etc is being increased. The issue of exploitation of victims of human traffic which provides for a wide range of offenders acts in this area is enough regulated in details.

At the same time attention should be paid to the perspectives for the development of criminal legal prevention of crime committing related to illegal migration. First of all, it seems appropriate to raise the issue of the criminal influence on legal entities regulation which is important in view of the increasing in recent years of humanitarian non-State actors who may unintentionally be assisting organized criminal smuggling networks, such as 
those involved in the development of apps to help irregular migrants travel ${ }^{26}$. The world community appeals to develop strategies to prevent and combat all illicit financial flows and emphasize the urgent need to adopt more effective measures to fight against economic and financial crimes, including fraud, as well as tax and corporate crimes, especially in their relevant transnational dimensions ${ }^{27}$.

In particular, it is expedient to expand the list of crimes in which criminal measures can be applied to legal entities at the expense of actions related to illegal migration. Furthermore, the socially dangerous activities of legal entities are by their nature purely economic and the criminal legal response to such activity should be specific.

It is also evident that it is advisable to displace preventive action towards the detection of criminal structures engaged in the organization of illegal migration, to establish links between different sections of criminal networks "responsible" for different stages of criminal activity. In particular, it is a necessity when investigating and prosecuting offences related to trafficking in persons and the smuggling of migrants, the concurrent undertaking financial investigations, with a view to tracing, freezing and confiscating proceeds acquired through those crimes, and the establishment of such crimes as predicate offences for money-laundering, as well as to enhance coordination and information-sharing among relevant agencies ${ }^{28}$.

Enforcement policy improving is also an important aspect as the courts today have a rather lenient attitude towards persons who commit crimes related to illegal migration. This is especially clearly manifests itself when punishing the human traffic. As the analysis has showed the courts mostly release offenders from punishment what does not facilitate crime prevention in the future.

\section{CONCLUSIONS}

The above allows to resume that illegal migration as a whole is a negative consequence of globalization, and that its features (directions, distribution of countries into donors, transiters and recipients) embody the regional specificity of certain territories. Herewith developing countries suffer more from illegal migration than countries which receive migrants.

\footnotetext{
${ }^{26}$ Facilitating migration and fulfilling rights - to reduce smuggling of migrants and prevent trafficking in persons. 4-5 September 2017, Vienna. URL: https://refugeesmigrants.un.org/ sites/default/files/ts5_gaatw.pdf

27 XIII United Nations Congress on Crime Prevention and Criminal Justice (Doha, 12-19 April 2015) URL: http://www.un.org/ru/events/crimecongress2015

28 XIII United Nations Congress on Crime Prevention and Criminal Justice (Doha, 12-19 April 2015) URL: http://www.un.org/ru/events/crimecongress2015
} 
Establishing responsibility for migration offenses is part of the state's current migration policy. Criminal liability is advisable to be provided concerning the most socially dangerous acts.

Studies of the illegal migration criminal legal survey show that its manifestations are embodied in crimes characterized by transnationality / transborderness, economic character, organizational structureness. At the present stage crimes related to illegal migration are a kind of shadow business. In addition, illegal migration acts as a background phenomenon facilitating the committing of various crimes by and against migrants themselves.

The subjective composition of socially dangerous acts testifies to the negative role of legal entities through or under the cover of which criminals are active. In addition, there is involvement of broad groups of the residents from around-the-border areas into criminal activity by forming stable antisocial ties between citizens of different countries, organizing corruption schemes with the authorities of neighboring states representatives' participation.

\section{SUMMARY}

The article is devoted to the illegal migration criminal legal survey. There is concluded that illegal migration prevention has to be an essence of state migration policy of Ukraine in terms of responsibility for migration offenses increasing.

There is found out that in the criminal legal survey the illegal migration is represented by crimes the specific features of which are transnationality / transborderness, economic character, organizational structureness. These crimes are referred in such articles of the Criminal Code of Ukraine: 332 "Illegal Transfer of Persons across the State Border of Ukraine", 332-2 "Illegal Crossing of the State Border of Ukraine", 149 "Human Traffic".

At the present stage crimes related to illegal migration form a kind of shadow business which is carried out not only by organized criminal organizations, but also by legal entities. This business also has a broad involvement of the around-the-border residents.

Perspectives for the development of such crimes criminal legal prevention are in improving the impact on legal entities and investigating concerning crimes that facilitate the processes of illegal migration (in particular, money laundering). 


\section{REFERENCES}

1. Key Global Migration Figures, 2017 - 2019. URL: https://migrationdataportal.org/sites/default/files/2019-08/key-globalmigration-figures.pdf

2. Camarota S.A. (2018) Non-Citizens Committed a Disproportionate Share of Federal Crimes, 2011-16. URL: https://cis.org/Camarota/ NonCitizens-Committed-Disproportionate-Share-Federal-Crimes-201116

3. Immigration Data from the U.S. Sentencing Commission "Interactive Sourcebook of Federal Sentencing Statistics". URL: https://isb.ussc.gov/api/ repos/:USSC:table_xx.xcdf/generatedContent?table_num=Table49

4. Arthur A.R. (2019) Are Criminal Aliens Above the Law? URL: https://cis.org/Arthur/Are-Criminal-Aliens-Above-Law

5. Ukrainske suspilstvo: mihratsiinyi vymir : natsionalna dopovid (2018) [Ukrainian society: migration survey : national report] Kyiv: Instytut demohrafii ta sotsialnykh doslidzhen im. M. V. Ptukhy NAN Ukrainy. 396 p. (in Ukrainian)

6. Irregular migration. URL: https://www.iom.int/key-migration-terms

7. Mizhnarodna terminolohiia u sferi mihratsii: ukrainsko-anhliiskyi tlumachnyi slovnyk [International terminology in migration sphere: Ukrainian-English dictionary] Kyiv: BLANK-PRES, 2015. 100 p. (in Ukrainian)

8. Filippov S.O. (2019) Protydiia transkordonnii zlochynnosti: hlobalnyi kontekst $i$ realii Ukrainy: monohrafiia [Countering cross-border crime: the global context and realities of Ukraine] Odesa: Feniks. 452 p. (in Ukrainian)

9. Stratehiia intehrovanoho upravlinnia kordonamy na period do 2025 roku [2025 Integrated Border Management Strategy]: Approved by the Cabinet of Ministers of Ukraine on July 24, 2019 № 687-p. URL: https://zakon.rada.gov.ua/laws/show/687-2019-\%D1\%80 (in Ukrainian)

10. Migrant Smuggling Data and Research: A global review of the emerging evidence base, Volume 2 / edited by A. Triandafyllidou and M.L. McAuliffe; International Organization for Migration, Geneva, 2014. 228 p.

11. Eastern Partnership Risk Analysis Network Quarterly; Quarter 2. April-June 2016, Frontex. Warsaw. 17 p.

12. Mihratsiinyi profil Ukrainy za 2017 rik (2018) [Ukraine`s Migration Profile for 2017]. State Migration Service of Ukraine. URL: https://dmsu.gov.ua/assets/files/mig_profil/migprofil_2017.pdf (in Ukraine)

13. Rezultaty operatyvno-sluzhbovoi diialnosti Derzhavnoi prykordonnoi sluzhby Ukrainy [The results of the operational and service activities of the State Border Guard Service of Ukraine]. URL: https://dpsu.gov.ua/ua/ activity/ohorona-kordonu (in Ukraine) 
14. Rezultaty diialnosti Derzhavnoi mihratsiinoi sluzhby Ukrainy [The results of the activities of the State Migration Service of Ukraine]. URL: https://dmsu.gov.ua/diyalnist/statistichni-dani/statistika-z-osnovnojdiyalnosti.html (in Ukraine)

15. U Natspolitsii tryvaie zahalnoderzhavna spetsoperatsiia "Mihrant» [National Migrant Special Operations Continues at National Police] URL: https://www.kmu.gov.ua/ua/news/u-nacpoliciyi-trivaye-zagalnoderzhavnaspecoperaciya-migrant (in Ukraine)

16. United Nations Convention against Transnational Organized Crime and the Protocols Thereto / UNODC. Vienna URL: https://www.unodc.org/ documents/middleeastandnorthafrica/organised-crime/united_nations_ convention_against_transnational_organized_crime_and_the_protocols_ther eto.pdf

17. XIII United Nations Congress on Crime Prevention and Criminal Justice (Doha, 12-19 April 2015) URL: http://www.un.org/ru/events/ crimecongress 2015

18. Erman G. (2018) Skil'ky nelehaliv khoche potrapyty do ES z Ukrayiny $i$ shcho $z$ nymy stayet'sya [How many illegals want to get to the EU from Ukraine and what happens to them] URL: https://www.bbc.com/ukrainian/ features-50220375 (in Ukraine)

19. Mezhdunarodnaya platforma deystviy $v$ tselyakh vypolneniya Protokola protiv nezakonnogo vvoza migrantov (2012) [International Platform for the Implementation of the Protocol against the Smuggling of Migrants] / UNODC. Vena. 180 p. [in Russian]

20. Facilitating migration and fulfilling rights - to reduce smuggling of migrants and prevent trafficking in persons. 4-5 September 2017, Vienna. URL: https://refugeesmigrants.un.org/sites/default/files/ts5_gaatw.pdf

\section{Information about the author: \\ Natalya Orlovska,}

Doctor in Law, professor,

Head of the Department of Criminal Law and Procedure, National Academy of the state Border Guard of Ukraine named after Bogdan Khmelnitsky 46 Schevchenko str., Khmelnitsky, Ukraine, 29001 ORCID ID: orcid.org/0000-0002-4400-560X 
DOI https://doi.org/10.36059/978-966-397-159-9/18-35

\section{CHARACTERISTIC FEATURES OF COMBATING CROSS-BORDER CRIME ON THE SEA ROUTES AND IN THE AIRSPACE}

\section{Stanislav Filippov}

\section{INTRODUCTION}

More than 420 million containers are moved around the world annually by sea, carrying $90 \%$ of the world's cargo. Only $2 \%$ of them are controlled ${ }^{1}$. Most of them are used for legal transportation, but some - for smuggling drugs, weapons and people. One sea shipment of contraband is ten times larger than the volume of automobile and hundreds of times - the volume of pedestrian ones. The situation poses a serious security risk, therefore in 2003 UNODC, together with the World Customs Organization, developed a Container Control Programme. The Programme aims to assist states in establishing a system to counter smuggling at seaports. Although, the causes of another problem, which is closely linked to cross-border crime on sea routes - mass migration movements caused by human rights violations, conflict and poverty, remain unresolved. In these conditions, migration by sea is a forced step for hundreds of thousands of people in the world to improve their lives. In these circumstances, tens of thousands are trafficked illegally, often in dangerous ways. High profits from the illicit cross-border trafficking of people and movement of drugs encourages criminals to search for alternative methods of transportation. The increase in forces and means for reliable border protection has a drawback - offenders are looking for ways to modernize their cross-border criminal activity.

In operational and service practice of Ukrainian law enforcement agencies there were cases of termination of offenses which were carried out by means of both construction of static objects (tunnels, pipelines), and by crossing the border using various vehicles (sea vessels of tourist class, rafts, ferries, uncontrollable railway carts, unmanned aerial vehicles). A special

1 Ukrayina pryyednalas' do hlobal'noyi systemy kontrolyu za nezakonnym obihom narkotykiv, zbroyi ta fal'syfikatu. [Ukraine has become a part of the global system of control over illegal drug trafficking, and that is counterfeit] 16.01.2018. Derzhavna fiskal'na sluzhba. Of.portal. URL: http://sfs.gov.ua/data/files/219105.pdf 
place in this regard belongs to the means of aviation. These circumstances together determine the relevance of this work

1. Combating cross-border crime in maritime space

The international community, in the course of many years of cooperation between the states in the maritime space, has accumulated experience in responding to the most common criminal threats in the modern world, such as: container smuggling, smuggling of illegal migrants and victims of trafficking by sea (often at risk to their lives), involvement of seamen in criminal offences abroad.

As for the problem of container smuggling, at the present stage of technology development, it is partially solved by scanning containers with various systems, such as MMPDS, which is common in many countries, a multi-mode passive system that is able to scan 100 percent of all cargo containers that enter ports. At the same time, this technology, mainly through a high standard of compliance with radiation safety requirements, is quite valuable, it is difficult to provide it to all ports, and when this happens, containers with contraband will obviously be overloaded at sea to smaller vessels that will avoid calling at ports where there is an automatic control system.

The Global Container Control Programme (GCCP) established by UNODC and the World Customs Organization has been in operation since 2004. The purpose of the GCCP is to prevent the illegal movement of drugs, weapons, counterfeit goods. As of 2018, 48 states were members of the GCCP. Ukraine, after its accession to the program, has introduced the port control units in the BCP «Odessa Commercial Sea Port» and «BoryspilAirport» (Air cargo). The state customs service gained access to the Container COMM information system, which was introduced by the World Customs Organization for the purpose of exchanging information on highrisk containers (type of cargo, route, payment methods, etc.) ${ }^{2}$. In general, the technological support of maritime traffic control is built taking into account the fact that the commission of offenses at sea involves extremely widespread logistics network, which includes ships, customs warehouses, dutyfree shops, etc. According to the UN Convention on the law of the sea (articles 3, 8, 33), the following maritime zones are established: inland waters, territorial waters, adjacent zone, IM (E) $Z^{3}$ (Fig. 1).

\footnotetext{
${ }^{2}$ Ibid

${ }^{3}$ United Nations Convention on the Law of the Sea (1982). URL: https://www.un.org/ depts/los/convention_agreements/texts/unclos/unclos_e.pdf
} 


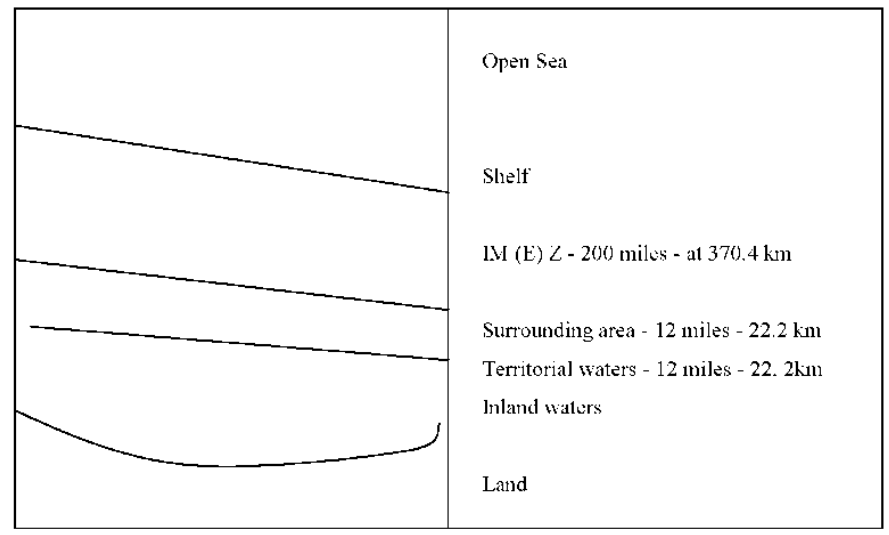

Fig. 1. Maritime zones according to the UN Convention on the law of the sea

It should be noted that the only body that in Ukraine is able (due to the availability of forces and means) to monitor the surface situation at sea and has the legal authority to stop, inspect non-military vessels that have committed violations of the law during navigation and stay in the adjacent zone, the territorial sea, internal waters, as well as vessels and watercraft that are working in the IM (E) Z, and stop working in the absence of permission of the SBGSU. Also the powers of the SBGSU include detaining vessels that violate the legislation on the IM (E) Z, the adjacent zone of Ukraine or the norms of international law, and deliver them to one of the ports of Ukraine open to foreign non-military vessels. The rights to detain or arrest ships and / or their crew members do not apply to warships and other government vessels used for non-commercial purposes ${ }^{4}$.

According to p. «g» part.5 article. 18 of the Law «On the organizational and legal basis of the fight against organized crime SBGSU is obliged to «carry out actions to control and detain Ukrainian and foreign non-military vessels».

Given the lack of forces and means to perform tasks being analysed of other public authorities, in our opinion, it should be resolved in a normative way participation of the marine guard of the SBGSU in various maritime operations under the auspices of FRONTEX, given that the authority of the

${ }^{4}$ Pro prylehlu zonu Ukrayiny : Zakon Ukrayiny vid 6 hrudnya 2018 r. [Adjacent Area of Ukraine: Law of Ukraine of December 6, 2018]. № 2641-VIII. URL: https://zakon.rada.gov.ua/ laws/show/2641-19/print 
marine protection of the SBGSU apply to the marine area of the state border with a length of 765 miles (of these, 509 miles - the Black sea, 132 miles the sea of Azov and 26 miles - the Kerch Strait. The length of the border river section along the Danube is 98 miles. The area IM (E) $\mathrm{Z}$ reaches over 21 thousand square miles. Since 2014, Ukraine has not controlled 413 miles of the marine area of the state border (of which 290 - in the Black sea, 97 in the Azov and 26 miles of the Kerch Strait). In IM (E) Z - more than 15 thousand square miles. The SBGSU carries out border control at 28 checkpoints for sea traffic in the waters of the Black and Azov seas and river Danube.

The 1982 UN Convention on the law of the sea grants the right to coastal states to establish laws and regulations relating to the peaceful passage across the territorial sea (article 21). The corresponding control is usually carried out in the adjacent area. The purpose of this control is the prevention within the territory or territorial sea of the coastal state of customs, immigration offenses, as well as bringing to justice for their commission. On these issues, such a state also has exclusive jurisdiction over artificial islands, installations and facilities in the exclusive maritime economic zone ${ }^{5}$.

The EU experience in reforming the system of combating cross-border threats in the maritime space is indicative. Since the functions of countering various threats at sea, including criminal, are performed by more than 300 different bodies and services of the EU member-states, in 2016, in addition to the creation of the European border and coast guard on the FRONTEX platform, the project «Coordination of the functions of the coast guard of the European Union» was implemented. It provides for the integration of technical (aviation, unmanned aerial vehicles, marine watercraft, and related surveillance equipment) capabilities of the three institutions for the joint implementation of tasks on the maritime border of the EU: FRONTEX (Warsaw, Poland - Border And Coast Guard, EMSA (Lisbon, Portugal) Maritime Security and EFCA (Vigo, Spain) - control over the extraction of biological resources.

Progress in changes in the criminal situation in the cross-border sphere becomes noticeable when the system of counteraction measures corresponds to the global nature of the threat. This can be demonstrated by the example of the formation of an unprecedented system of international political, legal, diplomatic and other (even military!) measures to combat crime related to the illegal transfer of migrants to the EU, which was formed in 2015-2016. This system provided for:

\footnotetext{
5 United Nations Convention on the Law of the Sea (1982). URL: https://www.un.org/depts/los/convention_agreements/texts/unclos/unclos_e.pdf
} 
adoption of agreements between the EU and transit countries (Turkey) and countries of origin of migrants ( 7 countries in Africa and 2 countries in the Middle East,

expanding the powers of the maritime forces of countries involved in combating cross-border crime (UN Security Council resolution No. 2240),

operations of international organizations to counter human trafficking and illegal migration,

institutional development of the system for countering cross-border threats,

naval operations (NATO in the Aegean sea),

globalization of the European border surveillance system (EUROSUR).

The crisis phenomena that were observed in Europe in 2015 stipulated if not revolutionary, then very non-standard answers. For example, such a nonstandard response may well be considered an unprecedented decision to use the forces and means of the military-political Alliance, which is NATO in a purely police operation in the Aegean sea ${ }^{6}$. This clearly demonstrates the international globalization of efforts to counter the global threat posed by cross-border crime associated with the smuggling of migrants. It is obvious that the effectiveness of combating smuggling on sea routes is associated with the effectiveness of joint international and interdepartmental activities, which, in turn, depends on the functional and operational compatibility of heterogeneous forces and means, including FRONTEX forces and the relevant regulatory norms.

A separate problem is the participation of Ukrainian citizens in crossborder criminal associations operating in the sea. The urgency of this problem is due to the increase in the number of cases of bringing Ukrainian sailors to responsibility by law enforcement agencies of foreign countries for the transportation of illegal migrants, as well as smuggling of explosives and tobacco products. As an example, let us recall the situation in the Mediterranean, which had a noticeable resonance in 2018. We are talking about dozens of Ukrainian sailors detained by law enforcement agencies of Greece and Italy for complicity in the illegal cross-border movement of migrants and smuggling. This happens mainly on the Mediterranean routes from Turkey to the countries of southern Europe. But there are other cases. For example, FRONTEX reports include information about citizens of Ukraine who were skippers of watercraft, who transported from Turkey to

6 Pilot project "creation of a european coastguard function" final report. URL: http://frontex.europa.eu/assets/Publications/General/Final_Report_EUCG.pdf 
Italy citizens of Pakistan, Syria, Iraq, Afghanistan, Iran and Somalia ${ }^{7}$. In particular, vessels with Ukrainians on Board were detained in ports of Greece, Italy, France, Spain, Libya and Nigeria. Members of the teams of these vessels are recruited, as a rule, in the Ukrainian black sea region, without even necessarily maritime skills, people usually are explained the real purpose, which is to transport migrants.

We quite agree with the thesis of Louise I. Shelley, who suggests that some categories of border areas are particularly vulnerable to transnational crime problems, as is the case in the above example, when recruitment of personnel is conducted for working on those Mediterranean (mainly) routes, which are characteristic also for the illegal transportation of migrants ${ }^{8}$.

For example, 12 sailors from the ship Mekong Spirit, accused of smuggling industrial explosives and detonators, were dismissed in Greece from custody in July 2018 by the efforts of the diplomatic institution of Ukraine. Based on media reports, this did not solve the legal problems associated with the investigation of specific crimes and, especially, with the prevention of crime in the field of migrant smuggling. On the contrary, a joint investigation would provide an understanding of the mechanism of those crimes committing, as well as elements of the system of determination of these crimes, such as victimization factors. Therefore, there would be exactly these situation data and information about the causal complex of crimes, the account of which is necessary when planning the necessary measures for both general social and special criminological crime prevention. Until now, it remains only to record the convictions of Greek justice against citizens of Ukraine, at least 150 of whom as of the end of 2018 were in Greece awaiting sentence for committing cross-border crimes ${ }^{9}$. And in general, as of 09.10.2018, more than 290 Ukrainian sailors were detained in penitentiary institutions abroad. In matters of preventive activities, it is necessary to take into account the specifics of the involvement of Ukrainian sailors in criminal activities, the reasons that prompted them to voluntarily agree to doubtful work, and, on this basis, to take the necessary measures to prevent cross-border crime. And these measures have to be

7 Risk Analysis FRAN.Q1.2017. Warsaw, July 2017. 37 p. P. 20 URL: https://frontex.europa.eu/assets/Publications/Risk_Analysis/FRAN_Q1_2017.pdf

${ }^{8}$ Shelley L. A Hazy Crisis: Illicit Cigarette Smuggling in the OSCE Region” July 19, 2017. P. 258 URL: https://www.csce.gov/sites/helsinkicommission.house.gov/files/Cigarette Smuggling.pdf

9 Filippov S. (2019) Protydiia transkordonnii zlochynnosti: hlobalnyi kontekst $i$ realii Ukrainy: monohrafiia [Countering cross-border crime: the global context and realities of Ukraine] Odesa: Feniks. 452 p. (in Ukrainian) 
planned taking into account the changing of environment, with correction, judging by estimates of their effectiveness ${ }^{10}$.

\section{Countering cross-border offences in airspace}

The cross-border use of aircraft in violation of the established procedure is a criminal offence regardless of the presence and nature of the cargo. Their application technically allows rapid transportation of persons and cargo without passing border control and without customs control. The logic of our work involves the study of criminologically significant aspects of combating crime in this area. The criminogenic danger of the use of aviation (including with small aircraft) is that this use is equivalent to the use of airspace in the interests of criminality, which allows one to quickly and bypassing border control transport a significant number of persons who may belong to the category of foreign terrorists-fighters, persons wanted for crimes, persons who are prohibited from entering / leaving, or irregular migrants. Also, air transport allows bypassing customs control to transport a variety of goods, as well as items and substances seized from civil and economic turnover. These circumstances actualize the study of the criminal potential of the use of aircraft for the purpose of committing cross-border crimes.

These circumstances require the study of criminal risks of the use of airspace in the border area. Based on the above, the purpose of this work is to study the dynamics and criminological features of the use of aircraft in the context of trends in cross-border crime. An additional objective is to forecast trends in criminology, taking into account the rapid development of the digital world in general and the technologization of crime in particular.

To achieve this goal, we used the analysis of scientific sources and official statistics to determine criminal threats in the use of airspace when crossing the state border, namely, the data of the Unified report on criminal offenses, as well as the analysis of the content of court decisions. The scientific study also provides for a comparative analysis of analytical data on the activities of operational and search units of the State border guard service of Ukraine and the data of the report of the Department of Homeland Security (DHS) of the United States (Agency, which includes the US Customs and Border Control - US CBP).

General characteristics of the rules governing international flights.

${ }^{10}$ Filippov S. (2019) The Smuggling of Tobacco Products in Europe: Criminogenic Potential Capacity. Baltic Journal of Law \& Politics. № 12 (1). P. 35-61. DOI: 10.2478/bjlp2019-0002. URL: https://content.sciendo.com/view/journals/bjlp/bjlp-overview.xml 
With the development of aviation in the thirties of the twentieth century there was a need for the regulation of criminal liability for violation of the rules of international flights. Obviously, in the conditions of the model of protection of the state border, which provided for the «iron curtain», the corresponding norm on criminal responsibility did not work in practice, since the aircraft violators were destroyed by means of air defense. All the more was resonance from actions of the unprofessional pilot, German citizen Matthias Rust, which on the 28 May 1987 on light plane «Cessna 172 Skyhawk» carried out the flight from Helsinki, without authorization crossed the state border of the USSR, without counteraction from Air Defense made a flight to Moscow and even landed on the Red Square. This case resulted in a change of Union legislation and amending the Law on state crimes of 1958 with an article «Violation of the use of airspace».

But in modern conditions, the purpose of international flight with violation of the established rules is often not air hooliganism, but illegal transportation of persons or objects across the state border. In general, an illegal act with this purpose may be qualified under the following provisions of the Criminal Code of Ukraine: article 334 «Violation of the rules of international flights», article 281 «Violation of the rules of air flights», article 204 «Illegal manufacture, storage, sale or transportation for the purpose of selling excisable goods». Also, the pilot is liable under article 204-1 of the Criminal Code «Illegal crossing or attempted illegal crossing of the state border of Ukraine». In recent years, with the participation of operational-search units of the SBGSU, a number of criminal offenses under article 334 of the Criminal Code of Ukraine «Violation of the rules of international flights» have been effectively stopped.

Therefore, an international flight is associated with crossing of the state border of Ukraine and another state by an aircraft, or a flight performed in the airspace of another state (other states) ${ }^{11}$. The offence in question may take the form of entry into or departure from Ukraine without a permit, as well as non-compliance with the routes and corridors specified in the permit, as well as echelons and landing places. In this case, the air route is a controlled airspace (or part of it) in the form of a corridor. The procedure for crossing the state border by aircraft is determined by the aviation rules of Ukraine. In particular, it is found that «aircraft cross the state border on

${ }^{11}$ Pravyla pol'otiv tsyvil'nykh povitryanykh suden u povitryanomu prostori Ukrayiny. Ministerstvo infrastruktury Ukrayiny, zatverdzheni nakazom Ministerstva infrastruktury Ukrayiny vid 28.10.2011 № 478. [Flight rules for civil aircraft in the airspace of Ukraine. Ministry of Infrastructure of Ukraine, approved by the order of the Ministry of Infrastructure of Ukraine] № 478. From October 28, 2011/ URL: https://zakon.rada.gov.ua/laws/show/z1327-11. 
specially designated routes, i.e. in a limited height and width of the airspace intended for crossing the border» ${ }^{12}$. Beyond these routes crossing the state border is possible in some cases, in fact, force majeure, for example, to perform emergency work or international agreements in the event of a natural disaster or by permission of the General Staff of the Armed Forces of Ukraine and coordination with the Administration of the SBGSU, or in the event of an emergency situation during the flight, which poses a threat to flight safety and human life ${ }^{13}$. The grounds for crossing the border by civil and state aircraft performing international flights with landing (departure) on (from) the territory of Ukraine is a permission to conduct flights and the presence of a flight plan. The basis for crossing the border by civil aircraft transiting through the airspace of Ukraine is the presence of a flight plan (section XI of the Aviation rules of Ukraine). In practice, this means that prior to the start of the flight with the crossing of state borders, the Air Traffic Service Authority (ATS) receives information about this in the format of the flight plan (flight plan - FPL).

It is also important that the navigational training of the crew, which performs an international flight, involves knowledge not only of the position of the corridors of flight, but also of the configuration of the border.

According to the Rules for 75-100 km before crossing the state border of Ukraine, the aircraft commander requests a dispatcher of an appropriate air traffic service a permission to cross the state border and report to him the echelon (height) of flight and the calculated time of flight over the state border of Ukraine ${ }^{14}$. During the crossing of the state border of Ukraine, the crew of the aircraft reports to the dispatcher the actual time of crossing and the echelon (altitude) of the flight. Crossing the state border by an aircraft without radio communication is prohibited. An aircraft that has crossed the state border of Ukraine without a permit or committed other violations of the rules of flight across the state border of Ukraine or the procedure of the runway of Ukraine shall be considered an aircraft-violator and shall be forced to land if it does not comply with the requirements of the air traffic

\footnotetext{
${ }^{12}$ Pro zatverdzhennya Aviatsiynykh pravyl Ukrayiny «Pravyla vykorystannya povitryanoho prostoru Ukrayiny : nakaz Derzhaviasluzhby Ukrayiny, Minoborony Ukrayiny vid 11 travnya 2018 № 430/210. [On approval of the Aviation Rules of Ukraine «Rules of use of the Ukrainian airspace: order of the State Aviation Service of Ukraine, Ministry of Defense of Ukraine of May 11, 2018 No. 430 / 210]. URL: https://zakon.rada.gov.ua/laws/show/z1056-18.

${ }^{13}$ Ibid.

${ }^{14}$ Pro zatverdzhennya Aviatsiynykh pravyl Ukrayiny «Pravyla vykorystannya povitryanoho prostoru Ukrayiny : nakaz Derzhaviasluzhby Ukrayiny, Minoborony Ukrayiny vid 11 travnya 2018 № 430/210. [On approval of the Aviation Rules of Ukraine «Rules of use of the Ukrainian airspace: order of the State Aviation Service of Ukraine, Ministry of Defense of Ukraine of May 11, 2018 No. 430 / 210]. URL: https://zakon.rada.gov.ua/laws/show/z1056-18 .
} 
control bodies. Ukrainian aircraft returning from abroad may cross the state border regardless of the availability of a flight permit. In the absence of such permission, the commander of the aircraft is obliged to land at the international airport determined by the Ukrainian Air Center (section XI of the Aviation rules of Ukraine). Therefore, violation of these norms on a manned aircraft is likely to have a consequence of prosecution under article 334 of the Criminal Code of Ukraine.

\section{Violation of the rules of international flights as a cross-border crime: some indicators of dynamics and geographical features}

Dynamics of registered according to the Unified report offenses under Art. 334 of the criminal code of Ukraine: in 2014, 18 crimes were registered, in $2015-1$, in $2016-4$, in 2017-2, in 2018- $5^{15}$.

For comparison, we present data on manned flights abroad. According to the U.S. Department of Homeland Security (DHS), from 2011 to 2016, smugglers made at least 534 illegal flights across the U.S. border in helicopters, single-engine aircraft or hang-gliders ${ }^{16}$ According to the press data of the period 2011-2017, there were recorded 562 such cases ${ }^{17}$. The offenses were recorded on the southern border of the United States with Mexico) in the States of Arizona, California, New Mexico and Texas. 98 percent of these offenses were related to the transportation of marijuana (seized 22,000 pounds (nearly 10 tons) of marijuana). Less than two percent of the crimes involved methamphetamine smuggling (nearly 8 kilograms of methamphetamine seized). The Report indicates that pilots fly primarily at low altitude over difficult to reach terrain, which makes it difficult for US CBP (Customs And Border Protection) agents to identify them. The plane can carry about 200 pounds $(90 \mathrm{~kg})$ of drugs. Pilots in most cases did not land in the United States, and dropped the cargo.

Indicative for Europe was the Mediterranean route from Morocco to Spain. Given the intensification of the efforts of the Spanish border guards at

15 Yedynyy zvit pro kryminal'ni pravoporushennya. Forma № 1 (misyachna) : nakaz Heneral'noyi prokuratury Ukrayiny vid 23 zhovt. 2012 r. № 100 [Report on criminal offenses. Form No. 1 (monthly): Order of the Prosecutor General's Office of Ukraine dated 23 October. 2012 № 100]. URL: https://www.gp.gov.ua/en/stst2011.html?dir_id=113897\&libid=.

${ }^{16}$ Border security: additional actions could strengthen dhs efforts to address subterranean, aerial, and maritime smuggling. gao-17-474: published: may 1, 2017. publicly released: may 1, 2017. url: https://www.gao.gov/assets/690/684408.pdf.

${ }^{17}$ Illicit drone flights surge along U.S.-Mexico border as smugglers hunt for soft spots. The Washington Post. June 24, 2018. URL: https://www.washingtonpost.com/world/nationalsecurity/illicit-drone-flights-surge-along-us-mexico-border-as-smugglers-hunt-for-softspots/2018/06/24/ea353d2a-70aa-11e8-bd50b80389a4e569_story.html?utm_term=.93f5b72c77f1 
sea, there is an increasing use of offenders' capabilities of small aircraft. In Spain with the use of aircraft the illegal migrants are smuggled in, as well as $\operatorname{drugs}^{18}$.

The court verdicts we analyzed in the period of 2015-2018 showed that all cases of prosecution under article 334 of the criminal code concerned the movement of tobacco products or illegal migrants.

It should be noted that cases of use of motor-paragliders by offenders are becoming more frequent. This is, among other things, due to the fact that a motor-paraglider or glider is subject to registration in the state register of civil aircraft, and the paraglider, motor-paraglider, hand-glider or deltaglider are exempt from these procedures. At the same time, these aircraft can be quickly put together and apart and have a load capacity from 30 to $100 \mathrm{~kg}$ of cargo. And the load capacity of modern motor hand-gliders allows you to transport several boxes of cigarettes, which makes it extremely cost-effective every flight on the Romanian, Hungarian, Slovak and Polish segment of the state border. Motor hand-gliders are equipped with a device for dumping cargo, which allows not to land and minimizes the possibility of termination of the pilot's activities on the territory of a foreign country.

There are quite dramatic examples of the illegal use of small aircraft to move cigarettes across the border. For example, according to Romanian press reports, the wreckage of a Ka-2 helicopter was found near the village of Sepinza in Romania on May 9, 2019. It is noted that the helicopter crossed the airspace of Romania illegally, and was transporting cigarettes. According to the press, the pilot was a 48 -year-old citizen of Belarus, who specially arrived from Minsk by train to Ukraine.

The use of unmanned aerial vehicles: the tendency of intensification of cross-border illegal activities in the coming years

The tendency of technical development of illegal cross-border activity (which causes its intensification) is the use of unmanned aerial vehicles (UAVs, drones) in the border area. An unmanned aircraft designed to perform a flight without a pilot on board, the flight control of which is carried out with the help of a special control station located outside the aircraft. Flights of unmanned aerial vehicles are carried out according to the requirements of Aviation regulations. Flights of unmanned aircraft weighing up to $20 \mathrm{~kg}$ inclusive are carried out without filing applications, without

\footnotetext{
${ }^{18}$ Filippov S. Dynamics and Geographical Distinctions of Crime connected with Migrants' Moving to Europe on Different Routes. NATO Science for Peace and Security Series - E: Human and Societal Dynamics. Addressing Security Risks at the Ukrainian Border Through Best Practices on Good Governance: Editors R. Kęsek at al. 2016. Amsterdam: IOS Press. Volume 129. 129 p. P. 21-27. URL: https://doi.org/10.3233/978-1-61499-710-8-21.
} 
informing the State border guard service of Ukraine, meeting the requirements of not crossing by the UAV of the state border of Ukraine.

According to the data based on the results of operational and service activity of the state border guard service of Ukraine, UAVs are used by offenders for such purpose as:

1) monitoring the movement of border guard details, observing of the order of service as for the time and manner;

2) identification of convenient places for preparation for committing an offense from the point of view of the terrain, other natural and geographical signs, economic activity of local population;

3) transportation of various items across the state border, most often tobacco products.

Cases of termination by units of border protection of such actions are already recorded by tens. In the area of the Western Regional Directorate and Lutsk Detachment in 2018 there were recorded and taken into account:

157 cases $(2017$ - 160) of violations of the state border of Ukraine in the airspace (45 UAVs, 2 aircraft, 110 aircraft were not classified);

19 cases of detention (identification) of aircraft (14 UAVs, 1 aircraft, 2 paratrakes, 3 motor hand-gliders (2017-8);

40 cases $(2017-11)$ of violations of flight rules in the zone with a special order of use of airspace (35 UAVs, 5 aircraft were not classified).

The tobacco products are most often smuggled using small aircraft, including unmanned ones,

The following examples of drone use by offenders are considered typical:

December 2018 - on the border sector of the Mukachevo Border Detachment was organized surveillance of the movement of border guard details with the help of a quadrocopter;

November 2018 - the transfer of 4,500 packs of cigarettes to Hungary using a drone was stopped at the border sector of the Chop Border Detachment;

October 2019 - at the border sector of the Chop Border Detachment, the smuggling of cigarettes into the territory of Slovakia using a quadrocopter was stopped;

August 2018 - a quadrocopter was flown from Romania and landed on the territory of one of the premises at the Mukachevo Border Detachment. When border guards identified the location of the quadcopter, the officer was attacked local residents. 
The latter case confirms the relevance of our study of the criminal potential of the activities of the local population of the border ${ }^{19}$. In fact, we again state that one of the factors that form criminal threats in the border area is the collaboration of the local population with crime, that is, what $\mathrm{N}$. A. Orlovska calls the criminal opposition to protective activity and the reason for which in the literature is called the illegal mentality ${ }^{20}$.

Obviously, it is necessary to analyze and take into account foreign experience, which confirms the constant increase in the number of cases of UAV use by offenders with the same purpose as in Ukraine, and already on a much larger scale. In particular, the first known case in China of crossborder movement of contraband goods on a large scale with the help of drones is considered to be a very illustrative example. In Shenzhen, a major technology center (the so-called Silicon valley of China), 26 people were arrested in February 2018 for smuggling smartphones worth about $\$ 80$ million from Hong Kong to Shenzhen using UAVs and other equipment. These individuals typically operated for 5 hours 15 nights a month, transferring from 10,000 to 15,000 smartphones per night ${ }^{21}$.

To counteract crime in the airspace in the border area the State border guard service of Ukraine at the end of 2018 used 21 UAV systems, each containing 3 UAVs listed in the state register of aircraft. These funds are subject to a significant quantitative increase in 2019. At the same time, there is an obvious need to ensure interdepartmental and cross-border cooperation and interoperability of law enforcement agencies. Indeed, counteraction to this phenomenon by the forces of only the border guard service loses its meaning, because:

airstrips are established outside the controlled border areas and beyond the territorial boundaries of the border guard units;

delivery of aircraft on the ground is carried out covertly in closed vehicles, often in a semi-disassembled form;

in case of movement across the border of various goods, objects, persons, offenders synchronize actions with other accomplices on time and a place.

19 Filippov S. (2017) Obyvatel'i transgranichnaya prestupnost'. [A Common man and Cross-border Crime]. Pravova derzhava (Constitutional State) No 28. P.107-112.

${ }^{20}$ Orlovskaya N (2018) [Criminal threats to the security of cross-border cooperation]. Kryminal'ni zahrozy bezpetsi transkordonnoho spivrobitnytstva. Visnyk Natsional'noyi akademiyi Derzhavnoyi prykordonnoyi sluzhby Ukrayiny. Yurydychni nauky. 2018. № 2. 2018. No. 2. URL: https://nadpsu.edu.ua/wp-content/uploads/2018/11/visnik_2_2018_ur.pdf.

${ }^{21}$ Gangs used drones and pulleys to smuggle $\$ 80$ million in smartphones from Hong Kong, officials say. The Washington Post. April 2, 2018. URL: https://www.washingtonpost.com/ news/morning-mix/wp/2018/04/02/gangs-used-drones-and-pulleys-to-smuggle-80-million-insmartphones-officials-say/?noredirect $=$ on\&utm_term $=.9960 \mathrm{~b} 6032 \mathrm{c} 8 \mathrm{c}$ 
So, in summary, we can note that this method of counteraction is actually reactive (in the context of responding to the challenges that have already emerged, and not ahead of time), and it is possible to use it only with significant funding, and in the digital world it is effective only if combined with other methods. The most important among them are economic (reduction of profitability of «air smuggling»), legal (revision of sanctions provided for «air crimes» at the border, possible criminalization of movement of certain groups of goods across the border), organizational (regarding cross-border law enforcement cooperation) ${ }^{22}$.

So, we have revealed the logic of the approach to the use of aircraft as a tendency that will determine the direction of intensification of cross-border illegal activities in the coming years.

On the basis of the identified threats, it is necessary to state that the problematic issues of combating cross-border crime in the field of aircraft use are concentrated in such areas:

1. Legal. The prospect of criminal liability has no deterrent effect because of the extreme leniency of sanctions. In case of using UAVs for committing cross-border offense, it is possible to bring an offender only to administrative responsibility, which does not deter this person.

2. Economic. The offender is motivated by the prospect of obtaining benefits, which is due to the extremely large difference in the prices of the goods being transported, and, accordingly - high profitability of the transportation.

3. Ensuring interdepartmental and cross-border cooperation and interoperability of law enforcement agencies.

4. Technical issues:

not all types of aircraft are subject to registration in the State Register of civil aircraft and not all aircraft have a SSR receiver-transmitter on board;

the use of modern aircraft with high technical characteristics (aircraft, navigation and lifting) will become more and more widespread. This should be provided for in the counteraction programmes, especially when budgeting for the purchase of equipment with characteristics higher than that used by offenders.

22 Filippov S. O. Zastosuvannya lital'nykh aparativ yak tendentsiya rozvytku transkordonnoyi zlochynnosti u tsyfrovomu sviti [The use of aircraft as a tendency of crossborder crime in the digital world]. Visnyk Natsional'noyi akademiyi Derzhavnoyi prykordonnoyi sluzhby Ukrayiny. Yurydychni nauky. Bulletin of the National Academy of State Border Guard Service of Ukraine. Legal science. 2018. Vol. 4. URL: http://nbuv.gov.ua/UJRN/vnadpcurn_2018_4_7 


\section{CONCLUSIONS}

1) The main efforts to counter cross-border threats on sea routes should be directed to countering the involvement of Ukrainian seamen in container smuggling and smuggling of illegal migrants and victims of human trafficking by sea. To do this, it is necessary to take measures to regulate the possibility of participation of Ukrainian law enforcement officers in FRONTEX maritime operations. In turn, the study of the deterministic complex of this phenomenon will be possible provided the organization of joint investigations under article 18 of the Agreement between Ukraine and the European Police Office on operational and strategic cooperation.

2) Criminology in its development cannot but take into account the rapid development of the digital world in general and the technologization of crime in particular. One of the forms of such technologization in the coming years will be the total use of the airspace with criminal purposes.

3) It is obvious that cross-border crime is already demonstrating the pattern in which this will occur. The aircraft, for example, will be used to: neutralize the technical system of crime prevention and to monitor the actions of law enforcement; preparation for committing of an offense by identifying convenient places in terms of security, access roads; rapid delivery of tools and means of committing a crime, etc.

4) Intensive development of UAVs, obviously, requires not only technological measures of counteraction, but also legal solutions that should regulate their use in special zones, as well as normative regulation of the use of artificial intelligence in UAV control systems to prevent crime. In this regard, innovative transformations depend on the susceptibility of the system to the introduction of the concept of «intellectual development» on the basis of regional clustering of combating cross-border crime.

Thus, promising areas of criminological research are grounded on the bases of new criminal tendencies caused by scientific and technological progress.

\section{SUMMARY}

The article describes the importance of of combating cross-border crime on the sea routes and in the airspace as an element of crime counteraction mechanism.

The problem, which is resolved to achieve this goal, is a theoretical analysis of the peculiarities of cross-border crimes, allowing to detect and otherwise counteract them using such an element of the counteraction mechanism. 
Strengthening the capacity of crime through the use of airspace and on the sea routes is a significant threat to border security, especially during the development of digital technologies. The article includes conclusions formulated on the basis of the worked out factual basis concerning 1) development of criminology taking into account the rapid development of the digital world in general and the tecnification of crime in particular;

2) formulated forecast of trends that will determine the use of aerial vehicles in the interests of cross-border crime;

3) advisable directions of criminological research through criminological knowledge extension with new branches caused by scientific and technological progress.

The article advanced an idea on the prospects of ontogenesis of the part of criminology devoted to the development of tecnification in various spheres.

In matters of preventive activities, it is necessary to take into account the specifics of the involvement of Ukrainian sailors in criminal activities, the reasons that prompted them to voluntarily agree to doubtful work, and, on this basis, to take the necessary measures to prevent cross-border crime. And these measures have to be planned taking into account the changing of environment, with correction, judging by estimates of their effectiveness.

\section{REFERENCES}

1. Ukrayina pryyednalas' do hlobal'noyi systemy kontrolyu za nezakonnym obihom narkotykiv, zbroyi ta fal'syfikatu. [Ukraine has become a part of the global system of control over illegal drug trafficking, and that is counterfeit] 16.01.2018. DFS. Of.portal. URL: http://sfs.gov.ua/data/files/ 219105.pdf

2. United Nations Convention on the Law of the Sea (1982). URL: https://www.un.org/depts/los/convention_agreements/texts/unclos/unclos_e.pdf

3. Pro prylehlu zonu Ukrayiny : Zakon Ukrayiny vid 6 hrudnya 2018 r. [Adjacent Area of Ukraine: Law of Ukraine of December 6, 2018]. № 2641VIII. URL: https://zakon.rada.gov.ua/laws/show/2641-19/print

4. Pilot project "creation of a european coastguard function" final report. URL:http://frontex.europa.eu/assets/Publications/General/Final_Report_EUCG. pdf

5. Warsaw Summit Communiqué Issued by the Heads of State and Government participating in the meeting of the North Atlantic Council in Warsaw 8-9.07.2016. URL: https://www.nato.int/cps/en/natohq/official_ texts_133169.htm 
6. Risk Analysis FRAN.Q1.2017. Warsaw, July 2017. 37 p. URL: https://frontex.europa.eu/assets/Publications/Risk_Analysis/FRAN_Q1_201 7.pdf

7. Filippov S. (2019) Protydiia transkordonnii zlochynnosti: hlobalnyi kontekst i realii Ukrainy: monohrafiia [Countering cross-border crime: the global context and realities of Ukraine] Odesa: Feniks. 452 p. (in Ukrainian)

8. Filippov S. (2019) The Smuggling of Tobacco Products in Europe: Criminogenic Potential Capacity. Baltic Journal of Law \& Politics. 12: 1. p. 35-61. URL: https://doi.org/10.2478/bjlp-2019-0002

9. Pravyla pol'otiv tsyvil'nykh povitryanykh suden u povitryanomu prostori Ukrayiny. Ministerstvo infrastruktury Ukrayiny, zatverdzheni nakazom Ministerstva infrastruktury Ukrayiny vid 28.10.2011 № 478. [Flight rules for civil aircraft in the airspace of Ukraine. Ministry of Infrastructure of Ukraine, approved by the order of the Ministry of Infrastructure of Ukraine] № 478. From October 28, 2011/ URL: https://zakon.rada.gov.ua/laws/show/z1327-11.

10. Pro zatverdzhennya Aviatsiynykh pravyl Ukrayiny «Pravyla vykorystannya povitryanoho prostoru Ukrayiny : nakaz Derzhaviasluzhby Ukrayiny, Minoborony Ukrayiny vid 11 travnya 2018 № 430/210. [On approval of the Aviation Rules of Ukraine «Rules of use of the Ukrainian airspace: order of the State Aviation Service of Ukraine, Ministry of Defense of Ukraine of May 11, 2018 No. 430 / 210]. URL: https://zakon.rada.gov.ua/ laws/show/z1056-18.

11. Yedynyy zvit pro kryminal'ni pravoporushennya. Forma № 1 (misyachna) : nakaz Heneral'noyi prokuratury Ukrayiny vid 23 zhovt. 2012 r. № 100 [Report on criminal offenses. Form No. 1 (monthly): Order of the Prosecutor General's Office of Ukraine dated 23 October. 2012 № 100]. URL: https://www.gp.gov.ua/en/stst2011.html?dir_id=113897\&libid=.

12. Border security: Additional Actions Could Strengthen DHS Efforts to Address Subterranean, Aerial, and Maritime Smuggling. GAO-17474: Published: May 1, 2017. Publicly Released: May 1, 2017. URL: https://www.gao.gov/assets/690/684408.pdf.

13. Illicit drone flights surge along U.S.-Mexico border as smugglers hunt for soft spots. The Washington Post. June 24, 2018.

14. Filippov S. (2016) Dynamics and Geographical Distinctions of Crime connected with Migrants' Moving to Europe on Different Routes. NATO Science for Peace and Security Series - E: Human and Societal Dynamics. Volume 129. 129 p. P. 21-27. URL: https://doi.org/10.3233/978-1-61499710-8-21. 
15. Filippov S. (2017) Obyvatel'i transgranichnaya prestupnost'. [A Common man and Cross-border Crime]. Pravova derzhava (Constitutional State) No 28. P.107-112.

16. Orlovskaya N (2018) [Criminal threats to the security of cross-border cooperation]. Kryminal'ni zahrozy bezpetsi transkordonnoho spivrobitnytstva. Visnyk Natsional'noyi akademiyi Derzhavnoyi prykordonnoyi sluzhby Ukrayiny. Yurydychni nauky. 2018. № 2. [Bulletin of the National Academy of State Border Guard Service of Ukraine. Legal science]. 2018. No. 2. URL: https://nadpsu.edu.ua/wpcontent/uploads/2018/11/visnik_2_2018_ur.pdf.

17. Gangs used drones and pulleys to smuggle $\$ 80$ million in smartphones from Hong Kong, officials say. The Washington Post. April 2, 2018. URL: https://www.washingtonpost.com/news/morning-mix/wp/ 2018/04/02/gangs-used-drones-and-pulleys-to-smuggle-80-million-insmartphones-officials-say/?noredirect $=$ on\&utm_term $=.9960 \mathrm{~b} 6032 \mathrm{c} 8 \mathrm{c}$

18. Filippov S. O. Zastosuvannya lital'nykh aparativ yak tendentsiya rozvytku transkordonnoyi zlochynnosti u tsyfrovomu sviti [The use of aircraft as a tendency of cross-border crime in the digital world]. Visnyk Natsional'noyi akademiyi Derzhavnoyi prykordonnoyi sluzhby Ukrayiny. Yurydychni nauky. Bulletin of the National Academy of State Border Guard Service of Ukraine. Legal science. 2018. Vol. 4. URL: http://nbuv.gov.ua/UJRN/vnadpcurn_2018_4_7

\section{Information about the author: Stanislav Filippov,}

Ph.D., Associate Professor, LTC Deputy Dean of the Law Enforcement Faculty Bohdan Khmelnytskyi National Academy of the State Border Guard Service of Ukraine 46 Schevchenko str., Khmelnitsky, Ukraine, 29007 ORCID ID: orcid.org/0000-0001-6700-4194 
DOI https://doi.org/10.36059/978-966-397-159-9/36-51

\section{COORDINATION OF ACTIVITY OF BODIES AND SERVICES PERFORMING DIFFERENT TYPES OF CONTROL AT THE STATE BORDER}

\section{Valerii Kukhar}

\section{INTRODUCTION}

Among the main functions of the SBGSU defined in article 2 of the Law of Ukraine «On the State Border Guard Service of Ukraine» is the coordination of activity of military formations and law enforcement agencies related to the protection of the state border and the activity of the state bodies, that perform various types of control when crossing the state border ${ }^{1}$.

The activity of the state bodies and various services that carry out various types of control when crossing the state border by persons, vehicles and transporting goods across it or participate in ensuring the regime at checkpoints are coordinated by the state border protection bodies also in accordance with part 1 of the article 25 of the Law of Ukraine «On border control» ${ }^{2}$. At the same time, inadequate coordination of the activity of the subjects of integrated border management is defined as one of the problems of integrated border management in the Strategy of integrated border management for the period up to $2025^{3}$.

Among the border management issues identified by the Strategy are:

the inadequacy of the infrastructure of checkpoints and access roads to the growing needs for processing capacity;

periodic complications in the operation of existing border crossing points due to seasonal and other changes in cross-border traffic flows;

inadequate condition of service areas and lack of comfortable conditions for travelers;

obsolescence of technical means of control;

${ }^{1}$ Pro Derzhavnu prykordonnu sluzhbu Ukrayiny: Zakon Ukrayiny vid 3 kvitnya 2003 roku [On the State border service of Ukraine: Law of Ukraine] No. 661-IV of 3 April 2003. URL: http://zakon3.rada.gov.ua/laws/show/661-15/print1533466816482616.

${ }^{2}$ Pro prykordonnyy kontrol': Zakon Ukrayiny Zakon Ukrayiny vid 5.11.2009 r. [On border control: the Law of Ukraine] of 5.11.2009 No. 1710-VI URL: http://zakon2.rada.gov.ua/ laws/show/1710-17/print1520522429510622

3 Stratehiya intehrovanoho upravlinnya kordonamy na period do 2025 r. Skhvalena rozporyadzhennyam KMU vid 24 lypnya 2019 r. № 687-r. [Integrated border management strategy]. Approved by the order of the CMU dated July 24, 2019 No. 687-R. URL: https://www.kmu.gov.ua/storage/app/uploads/public/5d6/904/d22/5d6904d225eb5667852251.doc 
low motivation and insufficient level of training of the personnel of subjects of integrated border management, their unwillingness to counteract corruption challenges. ${ }^{4}$

It is safe to say that some of these problems are directly or indirectly related to an inadequate level of coordination.

Moreover, the absence of the concept of «the state border at the checkpoint» does not allow purposefully and logically build technological lines of border, customs and other types of control, that are carried out at the checkpoint, to determine the responsibility of departments and officials for performing the tasks, functions and duties necessary for the implementation of the border crossing $^{5}$.

In turn, according to part 1 of the article 2 of the law of Ukraine «On border control», border control is a state control of the State border guard service of Ukraine that includes a set of actions and a system of measures aimed at establishing legal grounds for crossing the state border by persons, vehicles and moving goods through it, to counteract illegal movement of persons across the state border, illegal migration, human trafficking, and illegal movement of weapons, drugs, psychotropic substances and precursors, ammunition, explosives, materials and articles banned for transfer across the state border ${ }^{6}$.

At the same time, according to part 2 of article 2 of the Law of Ukraine «On border control», the purpose of border control is actually defined as counteraction to cross-border crime, it follows that the inconsistency of the activities of various control services at checkpoints across the state border negatively affects such counteraction, which determines the relevance of this work.

1. General characteristics of coordination of joint border activity

Ukraine has a developed network of border crossing points. The passage of persons and vehicles across the state border is carried out at 229 checkpoints (including control points), of which: 166-international, 28-interstate and 35local. By type of communication - 100 automobile, 57 rail, 29 sea, 28 air, 10 river, 2 ferry and 3 pedestrian checkpoints (including control points) ${ }^{7}$.

${ }^{4}$ Ibid

${ }^{5}$ Mostova K. (2017) Orhanizatsiyno-pravovi zasady prykordonnoho kontrolyu v punktakh peretynu derzhavnoho kordonu Ukrayiny [Organizational and legal basis of border control at the state border crossing points of Ukraine]. University scientific notes. No. 62, Pp. 241-254. P. 245.

${ }^{6}$ Pro prykordonnyy kontrol': Zakon Ukrayiny Zakon Ukrayiny vid 5.11.2009 r. [On border control: the Law of Ukraine] of 5.11.2009 No. 1710-VI URL: http://zakon2.rada.gov.ua/ laws/show/1710-17/print1520522429510622

7 Stratehiya intehrovanoho upravlinnya kordonamy na period do 2025 r. Skhvalena rozporyadzhennyam KMU vid 24 lypnya 2019 r. № 687-r. [Integrated border management strategy]. Approved by the order of the CMU dated July 24, 2019 No. 687-R. URL: https://www.kmu.gov.ua/storage/app/uploads/public/5d6/904/d22/5d6904d225eb5667852251.doc 
In fact, this infrastructure works in the interests of countering cross-border offenses - both administrative and criminal.

The analysis of historical experience shows that with the development of the state there was a clear tendency to increase the share of border control tasks in the total volume of tasks of the Border Guard Agency. If before 1960 their share was $10 \%$, in 1960-1982-30\%, in 1982-1991 their share was $45 \%$, then after 2003 (adoption of the law «On the State border guard service of Ukraine») already $70 \%$.

At first glance, the purpose of border control in accordance with the cited norm of the Law «On border control» is to counteract the acts provided for in articles 332, 149, 201, 305 of the Criminal Code of Ukraine. However, based on a comprehensive analysis of other norms of this and other Laws, it seems obvious that this list is not complete (in particular, we are talking, for example, about articles 332-1, 358, 204 and a number of other norms of the Criminal Code of Ukraine).

Ukraine borders with 7 States, 4 of them are EU members. The signing of the Association Agreement between Ukraine, the European Union, the European atomic energy community and their member States determined the strengthening of cooperation between Ukraine and the EU in the field of justice, freedom and security in order to ensure the rule of law and respect for human rights and fundamental freedoms. In this regard, it is necessary to take into account the peculiarities of the functioning of the system of combating criminal threats on the external borders of the European Union. It should be noted that the interests of Ukraine and neighboring States in this area coincide on such issues:

ensuring unhindered legal border crossing by persons and vehicles at checkpoints across the state border (hereinafter-BCP across the state border) in combination with a high level of control procedures;

proper management of migration flows,

effective counteraction to cross-border crime, especially its organized forms ${ }^{9}$

Therefore, often neighboring states seek to unify the technology of control procedures or organize joint border control. For example, in April 2018, Ukraine completed the procedure of ratification of the Agreement between the Cabinet of Ministers of Ukraine and the Government of the Republic of Moldova «On joint control of persons, vehicles, goods and objects at joint checkpoints across the Ukrainian-Moldovan state border». The analysis of the tasks of border control

${ }^{8}$ Stavytskyi, O. (2013) Teoriya i praktyka orhanizatsiyi ta zdiysnennya prykordonnoho kontrolyu v konteksti zabezpechennya natsional'noyi bezpeky Ukrayiny v prykordonniy sferi : monohrafiya.[Theory and practice of organization and implementation of border control in the context of national security in the border guard area: monograph]. Khmelnytskyi: NADPSU Publishing house. P. 90.

${ }^{9}$ Filippov S. (2019) Protydiia transkordonnii zlochynnosti: hlobalnyi kontekst i realii Ukrainy: monohrafiia [Countering cross-border crime: the global context and realities of Ukraine] Odesa: Feniks. 452 p. 
carried out in different States allows to draw a conclusion about a significant degree of similarity of these tasks in the context of their anti-criminal orientation. To illustrate this thesis, we will analyze the cross-border threats, which are counteracted at the line of border control.

The separation of cross-border criminal threats from all others is of a practical nature, primarily related to the peculiarities of countering them. In fact, the state border is a global filter, using which the states can take the necessary measures to ensure the most effective implementation of the functions of criminal justice. Border control in Ukraine contains:

1) verification of documents;

2) inspection of persons, vehicles, cargo;

3) execution of orders of law enforcement agencies of Ukraine;

4) verification of compliance by foreigners, stateless persons with the conditions of crossing the state border when entering, exiting and transiting through the territory of Ukraine;

5) registration of foreigners, stateless persons and their passport documents in BCPs through the state border;

6) inspection of vehicles in order to identify stolen vehicles.

Similar tasks are carried out in the course of border control in most European States. In this regard, let's detail performed by units of border control orders issued by authorized state bodies, that is, written instructions of the authorized state bodies about conducting in reference to certain individuals (in certain cases and in a certain way) of certain procedural, operational or special events.

Etymologically, the term «coordination» means coordination, bringing into line, establishing relationships, contact in the activity of people, between actions, concepts ${ }^{10}$. Despite this, it should be noted that the essence of coordination in the field of state border protection is to coordinate the goals, plans, content and forms of activity, resource potential of all state bodies and other units that ensure the state border regime. The main goal of the coordination is to achieve maximum efficiency in using the capabilities of public authorities in protecting the interests of the state in the border areas, maintaining reliable security of its borders. It is implemented by joint efforts of all subjects of coordination, taking into account the interests and specifics of their activities on the basis of jointly developed programs.

Various aspects of this problem are covered in the works of K. Mostova, O. Stavitsky, S. Filippov et al. However, the analysis of criminological and organizational-legal features of coordination by the state border protection bodies of the activity of control bodies and services exercising various types of control or taking part in ensuring the regime at checkpoints across the state border remained without attention. This is connected with the solution of the

${ }^{10}$ Suchasnyy tlumachnyy slovnyk ukrayins'koyi movy [Modern explanatory dictionary of the Ukrainian language] / ed. V. V. Dubichinsky. Kh.: VD «Shkola», 2008. P. 353. 
applied problem of coordination of subjects of prevention of cross-border crime. It should be noted that coordination in the fight against crime in the context of the prerogative of the prosecutor's office remains beyond the scope of our study.

Globalization and organized nature of crime at the state border require the unification and coordination of all operational and service activities of border protection agencies and the organization of comprehensive interaction with other law enforcement agencies that participate in the protection of state borders or perform other functions assigned by the state in the border areas and areas. Taking into account the experience of development and formation of law enforcement agencies of the European community, in order to qualitatively perform the tasks of the state border guard service of Ukraine, it is necessary to study the problems of coordination.

The results of the activity of law enforcement agencies, which are the subjects of law enforcement activity at the state border, to some extent depend on the well-established coordination of their actions and interaction between them.

There is a question of differentiation of these concepts. We believe that the goal of coordination is to create an appropriate regime of relations between the actors, in which the implementation of agreed tasks is achieved with the least effort, money and time. The purpose of interaction is the implementation of certain concerted actions aimed at achieving a specific result. In particular, the preparation of integrated plans, preparation of management decisions, coordination meetings belong to coordination. And the implementation of joint measures to detain the offender, carrying out complex measures to ensure border security is an interaction.

In addition, the presence or absence of subordination relationships between subjects. In contrast to interaction, in which the subjects are equal, that is, do not have authority over each other, during the coordination one of the subjects of the state border protection has the right to give binding instructions to other participants. The last criterion of differentiation is the purpose of coordination and interaction. The purpose of coordination of subjects of protection of the state border is creation of the corresponding mode of relations between these subjects at which performance of the agreed tasks by them is reached with the least expenses of forces, means and time. The purpose of interaction of subjects of protection of the state border is the implementation of certain concerted actions aimed at achieving a specific result.

Analysis of legislation that regulates the activity of bodies of executive power concerning ensuring of national security in the border area, showed that bodies of border protection solely posses the functions regarding the state border crossing by persons, vehicles and goods, maintain the established regime at the checkpoints, the illicit movement of persons across the state border, illegal migration, human trafficking, and illegal movement of weapons, drugs, psychotropic substances and precursors, ammunition, explosives, materials and 
articles prohibited for transfer across the state border. Customs and other state control bodies, ensuring economic and environmental security, under the existing legislation must ensure strict compliance with quotas for the import and export of industrial and agricultural products, the movement across the border of energy and other natural resources. Other bodies of the state control are obliged, providing ecological safety, to prevent transporting to the territory of Ukraine of diseases of epidemic character of people, animals, birds and plants. Practice shows that, while ensuring stability and evolutionary development of the country and environment, it is necessary to protect its space from external negative impact. The efforts of the control bodies at the checkpoints are aimed at achieving this goal. This task is solved in the conditions of continuously growing flow of persons and vehicles across the state border.

Coordination of activities of law enforcement, regulatory bodies and service providers is carried out on the grounds and in the manner specified in the Laws of Ukraine «On the State border guard service of Ukraine», «On border control», resolutions of the Cabinet of Ministers of Ukraine dated 18.01.1999 № 48 «On approval of Procedure of coordination of activity of bodies of executive power and bodies of local self-government on the issues of observance of regimes at the state border» dated 24.12.2003, No. 1989 «Issues of crossing the state border by persons, automobile, water, railway and air vehicles of carriers and goods transported by them», of 18.08.2010 № 751 «On approval of Provisions on checkpoints across the state border and control points», dated 22.08.2011 № 893 «On approval of Rules of sanitary protection of the territory of Ukraine».

In particular, according to the article 2 of the Law of Ukraine «On the State border guard service of Ukraine» the main functions of the State border guard service of Ukraine include coordination of the activity of military formations and law enforcement agencies related to the protection of the state border of Ukraine, and also activities of state bodies, carrying out various types of control when crossing the state border or contribute to the state border regime, the border regime and the regime at checkpoints across the state border of Ukraine. In fact, it means, among other things the coordination of bodies that are subjects of crime prevention.

According to part 5 of article 2 of the Law of Ukraine «On border control» border control is provided by coordinating the actions of control bodies and services. At the same time, according to article 1 of this Law, control bodies and services are state bodies and services that control the level of ionizing radiation, phytosanitary, veterinary and sanitary control, state control over compliance with legislation on food, feed, animal by-products, animal health and welfare. This provision cannot be considered well formulated, because it establishes that these bodies «carry out statutory inspections, which are performed in accordance with 
the legislation of Ukraine» ${ }^{11}$. Coordination at the state border, which is carried out by the border protection authorities, is a traditional practice not only for Ukraine. For example, according to article 16 of the Model Law «On border guard agencies (forces)», approved by the Resolution of the Interparliamentary Assembly of the CIS of May 17, 2012, the border guard agency in the field of border security coordinates the actions of executive authorities that perform sanitary-quarantine, veterinary, phytosanitary, automotive and other types of control at the state border, without interfering with the actions of such bodies. This model law refers to this type of coordination as «coordination of border guard activity», which is correct and reflects the essence of the phenomenon.

Let's consider the approaches to the general content of the concept of «coordination». In order to generalize scientific approaches to this term, it is possible to draw a conclusion that its contents are considered as a basis of relations between bodies of one organizational and legal level which is expressed in coordination of actions, decisions, in joint consultations, mutual discussions, conducting common actions. As a rule, these actions are performed by publication of joint acts between bodies, subjects of coordination. A similar approach is that coordination is a function that ensures coordination of the activity of management systems and coordination of actions not only of managers within the management level, but also of managers of other management structures.

M. M. Lytvyn defines coordination as a management function, the essence of which is « the establishment of horizontal links between the subjects and objects of management, that is, the implementation of a system of measures that ensure the achievement of the planned result. Coordination relations differ by types: coordination, technological interaction, hierarchical interaction ${ }^{12}$

Thus, characterizing the essence of coordination, Ukrainian scientists often focus on the interdependent, coordinated nature of the activity of various actors. It should be noted that in the context of the studied problem, the departmental normative-legal act defines coordination as a managerial function of the SBGSU, which unites and systematizes the efforts of control bodies and services to ensure the passage of persons, vehicles and goods across the state border according to the technological schemes/

Let us determine the place of the type of coordination we are analyzing in the system of integrated border management. M. M. Lytvyn distinguishes four levels of integrated border management: international, interstate, national, border

${ }^{11}$ Pro prykordonnyy kontrol': Zakon Ukrayiny Zakon Ukrayiny vid 5.11.2009 r. [On border control: the Law of Ukraine] of 5.11.2009 No. 1710-VI URL: http://zakon2.rada.gov.ua/ laws/show/1710-17/print1520522429510622

${ }^{12}$ Intehrovane upravlinnya kordonamy : pidruchnyk / za red. M. M. Lytvyna. [ntegrated Border Management: a textbook / ed. MM Litvin.] Khmel'nyts'kyy : Vyd-vo NADPSU, 2012. P. 46. 
guard. The border guard level of integrated management includes cooperation on the protection of the state border, compliance with the state border and border guard regime ${ }^{13}$. It is obvious that there are grounds to consider the coordination of activity of the state bodies and services on the organization and implementation of border control as a component of integrated management at the border guard level.

The spheres within which the central executive body implementing the state policy in the field of protection of the recreation area is coordinated, in fact, are the spheres of protective activity:

organization and implementation of the passage across the state border of persons, vehicles, cargo; compliance by all non-military vessels and warships with the established order of navigation and stay in the territorial sea, internal waters, as well as in the waters of border rivers, lakes and other bodies of water belonging to Ukraine;

carrying out various works, industrial and other activity on the state border within the border zone;

compliance with the border regime in the border zone and the controlled border area, the regime at checkpoints across the state border;

settlement of border incidents at the state border (border incident - an incident at the border that occurred as a result of illegal actions of local residents, military personnel or authorities of one or another party, including various violations of the border regime and agreements on border issues)\$ border.

involving citizens of Ukraine to participate in the protection of the state

2. Features of coordination of joint border activity

According to the order the purpose of coordination is to ensure compliance with the requirements of legislation on border issues, rational use of forces and means, avoiding duplication of measures taken to comply with law and order at the state border, as well as during the implementation of border, customs and other types of control. Based on the above, it can be concluded that coordination is designed to maintain a balance between effective activities to counter crossborder offenses and simplification of border guard formalities for law-abiding citizens. In case of martial law and state of emergency, the established coordination procedure does not apply. Classification of structural units of the state bodies, local governments, organizations that are subjects of coordination on the functional basis is given in table. 1 .

\footnotetext{
${ }^{13}$ Ibid, p. 103.
} 
Table 1

\section{Classification of coordination subjects}

\begin{tabular}{|c|c|}
\hline Group & List of coordination subjects \\
\hline $\begin{array}{l}\text { I group - } \\
\text { structural subdivisions of bodies } \\
\text { and organizations engaged in } \\
\text { various types of control of persons, } \\
\text { vehicles and goods abroad }\end{array}$ & $\begin{array}{l}\text { - customs authorities (after the separation of the } \\
\text { State Fiscal Service in 2019); } \\
- \text { veterinary and phytosanitary control bodies } \\
\text { (Minagroprom); } \\
- \text { control bodies of ionizing radiation of the } \\
\text { Ministry of Environmental Safety } \\
- \text { bodies of sanitary and quarantine control } \\
\text { (Ministry of Health); } \\
- \text { bodies of control over the movement of cultural } \\
\text { property of the Ministry of Culture; } \\
- \text { units of the inspectorate for safety on land } \\
\text { transport of the Ministry of Infrastructure (border } \\
\text { crossing points for automobile and railway } \\
\text { communications.)); } \\
- \text { the service of aviation safety (aviation service of } \\
\text { the Ministry of Infrastructure (border crossing points } \\
\text { for air traffic)); } \\
- \text { Maritime security service of the port (sea, river, } \\
\text { specialized) - Ministry of Infrastructure (checkpoints } \\
\text { for sea (river) communication)) }\end{array}$ \\
\hline $\begin{array}{l}\text { Group II - } \\
\text { Units of law enforcement agencies, } \\
\text { military formations, as well as } \\
\text { organizations entrusted with the } \\
\text { task of protecting objects, } \\
\text { protecting public order and } \\
\text { maintaining the regime at } \\
\text { checkpoints }\end{array}$ & $\begin{array}{l}\text { - structural units of the National police; } \\
\text { - structural units of air defense of the Ministry of } \\
\text { Defense of Ukraine; } \\
\text { - structural divisions of The State Migration } \\
\text { Service; } \\
\text { - paramilitary departmental and interdepartmental } \\
\text { protection; } \\
\text { - watchman service. }\end{array}$ \\
\hline $\begin{array}{l}\text { Group III - } \\
\text { Heads of local self-government } \\
\text { bodies, state bodies, enterprises, } \\
\text { institutions or organizations, on the } \\
\text { land plot of which there are } \\
\text { checkpoints (control points) }\end{array}$ & $\begin{array}{l}\text { - chiefs of sea (river) ports; } \\
\text { - chiefs of airports (airfields); } \\
\text { - chiefs of railway stations; } \\
\text { - heads of local governments. }\end{array}$ \\
\hline Group IV & $\begin{array}{l}\text { heads of the enterprises, institutions or organizations } \\
\text { that organize transportation across the state border }\end{array}$ \\
\hline
\end{tabular}

A systematic list of functions inherent in the coordination entities in the field of border guard activity is presented in table 2 . 


\section{Functions of the subjects of coordination in the field of border guard activities}

\begin{tabular}{|c|c|}
\hline $\begin{array}{c}\text { Subjects of } \\
\text { coordination }\end{array}$ & Main function \\
\hline $\begin{array}{l}\text { Custom authority } \\
\text { (after the division of } \\
\text { the SFS in 2019.) }\end{array}$ & $\begin{array}{l}-\quad \text { customs control and customs clearance of goods and vehicles; } \\
-\quad \text { the fight against smuggling and violations of customs rules; } \\
\text { - reconstruction, construction and arrangement of international } \\
\text { and interstate checkpoints across the state border for automobile } \\
\text { communication, as well as other functions }\end{array}$ \\
\hline $\begin{array}{l}\text { Ministry of } \\
\text { infrastructure }\end{array}$ & $\begin{array}{l}\text { - organization of transport communication across the state } \\
\text { border; } \\
- \text { reconstruction, construction, repair and maintenance of } \\
\text { checkpoints across the state border for rail, sea, river and air traffic; } \\
- \text { submission to the CMU of proposals for the creation of new } \\
\text { and changing the status of existing checkpoints across the state } \\
\text { border; } \\
- \text { addressing road construction issues in border areas; } \\
- \text { implementation of intergovernmental agreements on } \\
\text { international transport and control over aviation and railway } \\
\text { security, as well as other activities within the competence of the } \\
\text { Ministry of infrastructure }\end{array}$ \\
\hline $\begin{array}{l}\text { Ministry of Foreign } \\
\text { Affairs }\end{array}$ & $\begin{array}{l}\text { - coordination of the negotiation process with the adjacent states } \\
\text { and international organizations; } \\
-\quad \text { dealing with the issues of visa entry to Ukraine by foreign } \\
\text { citizens }\end{array}$ \\
\hline Ministry of defense & $\begin{array}{l}- \text { protection of the state border in the airspace by air defense } \\
\text { forces }\end{array}$ \\
\hline $\begin{array}{l}\text { Ministry of agrarian } \\
\text { policy and food }\end{array}$ & $\begin{array}{l}\text { - veterinary } 45 \text { and phytosanitary control at checkpoints across } \\
\text { the state border }\end{array}$ \\
\hline Ministry of health & $\begin{array}{l}\text { - sanitary and quarantine control, medical care of citizens at } \\
\text { checkpoints across the state border }\end{array}$ \\
\hline $\begin{array}{l}\text { Ministry of ecology } \\
\text { and natural resources }\end{array}$ & $\begin{array}{l}\text { - state control over compliance with the requirements of } \\
\text { legislation on environmental protection in the border zone, the } \\
\text { controlled border area and the exclusive (Maritime) economic zone } \\
\text { of Ukraine; } \\
- \text { environmental control at checkpoints across the state border }\end{array}$ \\
\hline National police & $\begin{array}{l}\text { - crime combating and prevention; } \\
\text { - ensuring public security and order within the border zone, } \\
\text { controlled border area }\end{array}$ \\
\hline $\begin{array}{l}\text { State migration } \\
\text { service }\end{array}$ & $\begin{array}{l}\text { - execution of the court decision on the forced expulsion of foreigners } \\
\text { and stateless persons from } \\
\text { Ukraine, as well as control over the correct and timely execution of } \\
\text { decisions on their forced return to the country of origin or a third country }\end{array}$ \\
\hline Ministry of culture & $\begin{array}{l}\text { - control at checkpoints across the state } \\
\text { border for the export from Ukraine and import into its territory of } \\
\text { cultural property }\end{array}$ \\
\hline $\begin{array}{l}\text { CM of the ARC, } \\
\text { local state } \\
\text { administrations and } \\
\text { local self-government } \\
\text { authorities }\end{array}$ & $\begin{array}{l}\text { - measures to comply with the border regime in the border zone } \\
\text { and the controlled border area; } \\
- \text { creating conditions for the operation of checkpoints across the } \\
\text { state border; } \\
- \text { general management of public organizations regarding the issues } \\
\text { of public order and state border protection }\end{array}$ \\
\hline
\end{tabular}


These tables demonstrate that despite the fact that combating crossborder crime is either not characteristic at all, or is a minor feature in the structure of activity of the majority of subjects of coordination, many of the features of the subjects border on issues of preventive activity (e.g., the activity of the Ministry of culture is directed on prevention of smuggling of cultural values).

In the course of implementation of the border control, the bodies of border protection perform orders of law enforcement agencies to detain individuals in the BCP who are prohibited from entering or leaving Ukraine. The legal basis of activities when solving this task by the agencies and subdivisions of state border protection are Laws of Ukraine «On the state border of Ukraine», «On State border guard service of Ukraine», «On border control», «On combating terrorism», «On procedure of exit from Ukraine and entry into Ukraine of citizens of Ukraine», «On legal status of foreigners and persons without citizenship», decrees of the Cabinet of Ministers of Ukraine «On approval of Rules of crossing the state border by citizens of Ukraine», «On the procedure of providing the State border guard service and the fulfilment of the instructions of law enforcement bodies concerning persons who cross the state border of Ukraine», etc.

It should be noted that the bodies of the SBGSU can be both subjects and objects of coordination. For example, according to the Concept of counterterrorism, increasing the level of coordination of counter-terrorism actors is one of the tasks in this area. It is obvious that the SBGSU bodies in this context are objects of coordination ${ }^{14}$.

In general, performing of orders of law enforcement agencies is organized and carried out by units of the state border protection at checkpoints equipped with complexes of automated technical means of information and telecommunication system $\mathrm{PK}$ «Gart- $1 / \mathrm{P} »$ in the same manner as in the control of persons who are prohibited from entering Ukraine. Depending on features of the organization of documents checking, arrangement and equipment of $\mathrm{BCP}$, the accounting of the orders of law enforcement bodies are performed in special sections of information storage in a certain form. At the same time, the records should contain a minimum set of data necessary to identify wanted persons without disclosing the direct content of the operational task. Depending on the type of the BCP and the conditions of the situation, the verification of the grounds for the right to cross the state border by vehicles and goods is carried out in the process of checking documents or is a separate technological operation.

It is important to ensure a high level of interaction between the control bodies that carry out their activity on the routes of international

${ }^{14}$ Kontseptsiya borot'by $\mathrm{z}$ teroryzmom v Ukrayini. Zatverdzhena Ukazom Prezydenta Ukrayiny vid 5 bereznya 2019 roku № 53/2019 [The concept of combating terrorism in Ukraine]. Approved by presidential decree No. 53/2019 of 5 March 2019. URL: http://www.rnbo.gov.ua/documents/493.html 
communications (through the introduction of the interdepartmental information and telecommunication system «Arkan»), as well as to equip checkpoints with technical means that allow in the shortest possible time to identify any vehicle, or the nature of their cargo for the purpose of further targeted inspection.

As it is noted by K. V. Mostova, the activities of border control units is based on the obtaining, synthesis, analysis and implementation of diverse information. It has its own structure, reveals the technology of the main operations and actions for the implementation of border control. A large amount of diverse information, the constant dynamics of the operational situation (with a change in the category of issued citizens and other conditions) means hard work on the analysis, synthesis, classification, systematization of the accumulated material and its distribution. In the conditions of the border control technology rigidly regulated by normative legal acts, the personnel independently carry out planning of sequence of actions, makes the decisions corresponding to the developing situation in the BCP. Such actions are successful provided that the special skills of the personnel of the units of border protection are firmly formed. Thus, the increasing demands of the system of ensuring national security in the border guard sphere to the nature of the activity of bodies and divisions of the state border protection defines the border control as an independent direction of the operational and service activity of the SBGS of Ukraine. As an independent direction of operational and service activity, border control should have its own hierarchy of management, built on automated, systemically integrated information flows, connected not only by technical parameters, but also distributed by qualification characteristics by types of information, which is implemented at the appropriate levels of management. The border control should have independent directions of formation of requirements, creation, introduction, operation and improvement of technical means of the border control. Autonomous areas of recruitment, training and placement of personnel, which not only take into account the necessary qualification requirements for personnel from the point of view of peacetime, but also the necessary organizational and staff structure of the application of the units of border protection in the event of emergencies, crisis situations and armed conflicts. The border control system should be built in accordance with the operational and service tasks the SBGSU is faced with as a whole and the specific tasks of the bodies of the state border protection in the relevant region, as well as on the basis of legally defined responsibilities ${ }^{15}$.

Executive authorities and local self-government bodies are responsible for drawing up interaction plans. The plans define the main general measures

${ }^{15}$ Kęsek R., Boroda M., Jóźwik Z. Addressing Security Risks at the Ukrainian Border Through Best Practices on Good Governance. 2016. Vol. 129. Amsterdam. pp. 21-27. https://doi.org/10.3233/978-1-61499-710-8-21 
aimed at the prevention, timely detection and suppression of cross-border offenses and any other violations of legislation on border guard issues. Addressing the question of determining the role of coordination in combating cross-border crime, we note that in order to ensure timely and full information on the state border protection, executive and local authorities, bodies exercising various types of control while crossing the state border or participating in ensuring the regime at checkpoints across the state border, act according to the elements of interaction, which include the exchange of information through the service control centers and areas of interaction specified in table 3 .

Table 3

\section{The essence of the interaction on regimes compliance nat}

the state border: the preventive aspect

\begin{tabular}{|c|c|}
\hline \multicolumn{2}{|r|}{ Area of cooperation } \\
\hline $\begin{array}{l}\text { Development and } \\
\text { implementation of }\end{array}$ & $\begin{array}{l}\text { joint activities to identify and disclose } \\
\text { violations of legislation on border and customs issues }\end{array}$ \\
\hline $\begin{array}{l}\text { Identification and } \\
\text { disclosure of }\end{array}$ & crimes, including in the sphere of foreign economic activity \\
\hline The search and arrest & of criminals \\
\hline Counteraction & to illegal migration \\
\hline & smuggling of goods and other items across the state border; \\
\hline Organization & of traffic safety of vehicles of international communication. \\
\hline \multicolumn{2}{|r|}{ Exchange of information } \\
\hline Intentions and attempts & $\begin{array}{l}\text { to violate the state border } \\
\text { and detention of its violators }\end{array}$ \\
\hline Signs of preparation & to violation of the state border \\
\hline $\begin{array}{l}\text { Locations of gathering } \\
\text { and routes }\end{array}$ & of illegal migrant; \\
\hline Identification of persons & $\begin{array}{l}\text { concerning which there are corresponding } \\
\text { instructions of law enforcement agencies }\end{array}$ \\
\hline $\begin{array}{l}\text { Attempts to move across } \\
\text { the border }\end{array}$ & $\begin{array}{l}\text { by wanted criminals, including those from international crimina } \\
\text { groups }\end{array}$ \\
\hline Evidence & $\begin{array}{l}\text { of the acts of sabotage, terrorist acts, provocative actions and } \\
\text { conflict situations at checkpoints across the state border, in the } \\
\text { border zone and the controlled border area }\end{array}$ \\
\hline Evidence and channels & $\begin{array}{l}\text { of illegal movement across the state border of goods and other } \\
\text { items, currency, raw materials, hazardous substances and waste, } \\
\text { cultural and historical values, stolen vehicles }\end{array}$ \\
\hline
\end{tabular}

\section{CONCLUSIONS}

Summing up, we note that the problem of optimizing the system of ensuring the protection of the state border of Ukraine requires a solution at the legislative level. In the Law of Ukraine «On the state border of Ukraine» it is necessary to clearly define the powers of public authorities engaged in the protection of the state border regime of Ukraine, the mechanism of their 
interaction and coordination. Protection of the state border of Ukraine is carried out by a fairly extensive system of public authorities. Given this, an important aspect of such a system is the coordination of the activity of its actors. The above shows that the main vector of coordination of activity of the state bodies and services on the organization and implementation of border control is aimed at maintaining a balance between effective activity to counter cross-border offenses and simplification of border formalities for law-abiding citizens.

In the field of movement of goods with the aim of introducing the concept of «smart borders» and the best European practices necessary to realize such tasks as: a) control of cross-border movement of goods through the introduction of electronic identification of goods and introduction of taxinvoice or e-invoice; b) introduction of common transit system with the neighboring countries (at least EU), which will allow the direct exchange of the databases of customs authorities of neighboring countries; analysis of import prior to arrival of goods at the customs border, which will oppose the importation of counterfeit goods as «interrupted transit»; c) integration of the customs databases of the neighboring states in the regime of «querysharing»; d) improving control of international travels of citizens.

Particular attention should be paid to the provision of authorized bodies with the authority to collect, process and store personal data; ensuring the effectiveness of software and analytical tools for processing PNR (Passenger Name Record); interoperability of databases of the SBGSU, other law enforcement agencies and Interpol; prevention of cross-border movement of terrorists and related assets, including through the use of border control units of Interpol databases, the use of API (notification by transport companies of passenger data before arrival for border control), various ways to ensure the protection of travel documents.

\section{SUMMARY}

The results of the activity of law enforcement agencies, which are the subjects of law enforcement activity at the state border, to some extent depend on the well-established coordination of their actions and interaction between them.

To resolve this problem, the following questions have been answered: what is the importance of the $\mathrm{BC}$ nowadays in the system of counteraction to criminal threats in general ? what aspects of border crossing points across the state border have the greatest impact on the effectiveness of coordination? Special emphasis is what trends will determine the effectiveness of the coordination in the context of counteracting crime. As an 
independent direction of operational and service activity, border control should have its own hierarchy of management, built on automated, systemically integrated information flows, connected not only by technical parameters, but also distributed by qualification characteristics by types of information, which is implemented at the appropriate levels of management. The aim of coordination is to optimize the joint border activity of the state border guard service and control services. Including: regulating the order of actions in case of non-standard situations; ensuring smooth functioning of border crossing points; ensuring compliance with the requirements of legislation on border issues; rational use of available forces and means. Special emphasis is avoiding duplication of control procedures, compliance with regime rules, maintaining the openness of the border for legitimate cross-border activities.

\section{REFERENCES}

1. Pro Derzhavnu prykordonnu sluzhbu Ukrayiny: Zakon Ukrayiny vid 3 kvitnya 2003 roku [On the State border service of Ukraine: Law of Ukraine] No. 661-IV of 3 April 2003. URL: http://zakon3.rada.gov.ua/laws/show/661-15/print1533466816482616.

2. Pro prykordonnyy kontrol': Zakon Ukrayiny Zakon Ukrayiny vid 5.11.2009 r. [On border control: the Law of Ukraine] of 5.11.2009 No. 1710VI URL: http://zakon2.rada.gov.ua/laws/show/1710-17/print15205224295 10622 .

3. Stratehiya intehrovanoho upravlinnya kordonamy na period do 2025 r. Skhvalena rozporyadzhennyam KMU vid 24 lypnya 2019 r. № 687-r. [Integrated border management strategy]. Approved by the order of the CMU dated July 24, 2019 No. 687-R. URL: https://www.kmu.gov.ua/ storage/app/uploads/public/5d6/904/d22/5d6904d225eb5667852251.doc

4. Mostova K. (2017) Orhanizatsiyno-pravovi zasady prykordonnoho kontrolyu $\mathrm{v}$ punktakh peretynu derzhavnoho kordonu Ukrayiny [Organizational and legal basis of border control at the state border crossing points of Ukraine]. University scientific notes. No. 62, Pp. 241-254. P. 245.

5. Stavytskyi, O. (2013) Teoriya i praktyka orhanizatsiyi ta zdiysnennya prykordonnoho kontrolyu $\mathrm{v}$ konteksti zabezpechennya natsional'noyi bezpeky Ukrayiny $\mathrm{v}$ prykordonniy sferi : monohrafiya.[Theory and practice of organization and implementation of border control in the context of national security in the border guard area: monograph]. Khmelnytskyi: NADPSU Publishing house. 360 p. 
6. Filippov S. (2019) Protydiia transkordonnii zlochynnosti: hlobalnyi kontekst i realii Ukrainy: monohrafiia [Countering cross-border crime: the global context and realities of Ukraine] Odesa: Feniks. 452 p.

7. Suchasnyy tlumachnyy slovnyk ukrayins'koyi movy [Modern explanatory dictionary of the Ukrainian language] / ed. V. V. Dubichinsky. Kh.: VD «Shkola», 2008. $832 \mathrm{p}$.

8. Intehrovane upravlinnya kordonamy : pidruchnyk / za red. M. M. Lytvyna. [ntegrated Border Management: a textbook / ed. MM Litvin.] Khmel'nyts'kyy : Vyd-vo NADPSU, 2012. P.46

9. Filippov S., Maltsev A., Voitsekhivskyi O. Osoblyvosti koordynatsiyi diyal'nosti derzhavnykh orhaniv i sluzhb z pytan' orhanizatsiyi ta zdiysnennya prykordonnoho kontrolyu. Mytna sprava/ [Features of coordination of activity of the state bodies and services concerning the organization and implementation of border control. Customs matter]. 2013. No. 1 (85). Part 2. book 2. p. 105-113 + 4 p. Attachment

10. Kontseptsiya borot'by $\mathrm{z}$ teroryzmom $\mathrm{v}$ Ukrayini. Zatverdzhena Ukazom Prezydenta Ukrayiny vid 5 bereznya 2019 roku № 53/2019 [The concept of combating terrorism in Ukraine]. Approved by presidential decree No. 53/2019 of 5 March 2019. URL: http://www.rnbo.gov.ua/documents/493.html

11. Kęsek R., Boroda M., Jóźwik Z. Addressing Security Risks at the Ukrainian Border Through Best Practices on Good Governance. 2016. Vol. 129. Amsterdam. pp. 21-27. https://doi.org/10.3233/978-1-61499-710-8-21

\section{Information about the author:} Valerii Kukhar,

$\mathrm{PhD}$ in Law, Associate Professor, Dean of the Law Enforcement Faculty Bohdan Khmelnytskyi National Academy of the State Border Guard Service of Ukraine 46 Schevchenko str., Khmelnitsky, Ukraine, 29007 ORCID ID: orcid.org/0000-0002-9627-2953 
DOI https://doi.org/10.36059/978-966-397-159-9/52-68

\section{CRIMINAL PROCEEDINGS REGARDING ENFORCED DISAPEARANCE IN UKRAINE: ISSUES OF NORMATIVE REGULATION}

\section{Iryna Hloviuk}

\section{INTRODUCTION}

International Convention for the Protection of All Persons from Enforced Disappearance of adopted on 20 December 2006 (Convention) came into effect in Ukraine on 13 September 2015. Under Convention, no one shall be subjected to enforced disappearance. No exceptional circumstances whatsoever, whether a state of war or a threat of war, internal political instability or any other public emergency, may be invoked as a justification for enforced disappearance. For the purposes of this Convention, «enforced disappearance» is considered to be the arrest, detention, abduction or any other form of deprivation of liberty by agents of the State or by persons or groups of persons acting with the authorization, support or acquiescence of the State, followed by a refusal to acknowledge the deprivation of liberty or by concealment of the fate or whereabouts of the disappeared person, which place such a person outside the protection of the law.

Convention also prescribes a number of procedural rules which should be considered in the course of criminal proceedings regarding offence of enforced disappearance (particularly, Articles 3, 8, 10, 11, 12, 14, 17, 24 etc.). Despite the significance of these aspects for contemporary lawenforcement practice, there are no special studies in Ukraine on issues of criminal proceedings regarding enforced disappearance. That is why the goal of the research is to identify issues of ensuring the provisions of Convention by procedural means of domestic legislation.

\section{Issues of pre-trial investigation and placement in public or private custodial settings}

Enforced disappearance is an offence of public prosecution so information shall be entered in the Integrated Register of Pre-Trial Investigations (IRPI), and pre-trial investigation shall be instituted without a victim's application. 
Thorough and impartial investigation as a requirement of Convention suggests that the investigation shall be effective, that is, to meet the criteria established by the case-law of European Court of Human Rights (ECtHR), in particular for cases of enforced disappearance involving deprivation of life. Since all international human rights agencies recognize the state's obligation to account for a detainee's fate. Considering the difficulties of proving the State's involvement in certain cases of enforcement disappearance characterized by unlawful detention, it is the state's responsibility to account for the disappeared persons fate. In that regard, the state may be found responsible for violation of right to life in cases when the body of the missing person was not found. After a brief hesitation ECtHR joined the practice of United Nations Human Rights Committee and Inter-American Court of Human Rights and acknowledged the presumption of facts and shifts of burden of proof onto the state for the cases of disappearances when victims were last seen in places under the Government's control, in the absence of direct evidence that persons concerned were not detained (Imakayeva v. Russia, para. 115, Tanis v. Turkey, para. 160, 206-210; Varnava and others v. Turkey, para. 181-186). Government's inability to provide satisfactory and convincing explanation as to what happened to the disappeared persons, together with the presumption of their death, could also result in a violation of right to life by the Government ${ }^{1}$. For instance, in case of 'Imakayeva v. Russia', ECtHR stated that where the events in issue lie wholly, or in large part, within the exclusive knowledge of the authorities, such as in cases where persons are under their control in custody, strong presumptions of fact will arise in respect of injuries and death occurring during that detention. Indeed, the burden of proof may be regarded as resting on the authorities to provide a satisfactory and convincing explanation. These principles apply also to cases in which, although it has not been proved that a person has been taken into custody by the authorities, it is possible to establish that he or she entered a place under their control and has not been seen since that time. In such circumstances, the onus is on the Government to provide a plausible explanation as to what happened on the premises and to show that the person concerned was not detained by the authorities, but left the premises without subsequently being deprived of his or her liberty (paras. 114, 115). The Court has also found in many cases concerning disappearances that a missing person may be presumed dead.

\footnotetext{
${ }^{1}$ Khrystova H. Pro pozytyvni zoboviazannia derzhavy stosovno prav liudyny v umovakh zbroinoho konfliktu ta yoho naslidkiv [On positive obligations of the state regarding human rights in conditions of armed conflict and its consequences]. Retrieved from https://rm.coe.int/native/168072b3cf (accessed 16 October 2019).
} 
The Court has made findings of presumptions of deaths in the absence of any reliable news about the disappeared persons for periods ranging from four years to more than ten years ('Sultygov and others v. Russia', paras. $395,396)$.

The offence provided for by Article 146-1 Para. 1 of Criminal Code of Ukraine (CC of Ukraine) is subject to the jurisdiction of the investigative bodies of the National police, except for cases when it is subject to jurisdiction of the investigative bodies of State Bureau of Investigation under rules of personal jurisdiction. As argued by $\mathrm{B}$. Babin ${ }^{2}$ the fact that the offence provided for by Article 146-1 of CC of Ukraine is subject to jurisdiction of the National police is quite controversial. Considering that allegations of enforced disappearance in Ukraine are usually made against the officials of Security Service of Ukraine, military service and the National police itself (as well as disappearances made by agents of the countryaggressor) it is too optimistic to expect the effectiveness from investigators of the National police.

The offence provided for by Article 146-1 Para. 1 of CC of Ukraine is an offence of medium gravity, thus no covert investigative (detective) actions could be conducted in course of criminal proceedings save for collecting information from electronic information systems or parts thereof the access to which is not restricted by the system's owner, possessor or keeper or is not related to circumventing a system of logical protection and establishing the location of a radio electronic device. As regards the offence provided for by Article 146-1 Para. 2 of CC of Ukraine that is a grave crime, there is no limitations as to conduct of covert investigative (detective) actions. However, it should be noted that, even in exceptional cases related to preventing the commission of crime provided for by Article 146-1 Para. 1 of $\mathrm{CC}$ of Ukraine, there is no possibility to conduct covert investigative (detective) actions (i.e., establishing the location of a radio electronic device (Article 268 Para. 4 of Code of Criminal Procedure of Ukraine (CCP of Ukraine); surveillance of an individual (Article 269 Para. 3)) as Article 250 of CCP of Ukraine allows such procedure only in case of prevention of commission of grave crimes or crimes of exceptional gravity that are set out in Chapters I, II, VI, VII (Articles 201 and 209), IX, XIII, XIV, XV, XVII of Special Part of CC of Ukraine, which is inappropriate considering the specifics of the offence provided for by Article 146-1 Para. 2 of CC of

\footnotetext{
${ }^{2}$ Babin B. (2019, February 24) Nasylnytski znyknennia v Ukraini. Pravovi deklaratsii ta realii viiny [Enforced disappearances in Ukraine. Legal declarations and realities of war]. Ukrainska Pravda. Retrieved from https://www.pravda.com.ua/columns/2019/02/24/7207525/ (accessed 16 October 2019).
} 
Ukraine as well as victim's vulnerability and difficulties connected to their protection.

Certain questions arise regarding the access to public or private custodial settings. According to Convention every State party shall ensure that the authorities referred to in paragraph 1 of this article (i.e., conducting investigation): $b$ ) have access, if necessary with the prior authorization of a judicial authority, which shall rule promptly on the matter, to any place of detention or any other place where there are reasonable grounds to believe that the disappeared person may be present. However, the provisions of current legislation are not completely in compliance with that rule. For instance, Law of Ukraine 'On pre-trial detention' provides that the administration of place of pre-trial detention is obliged to: create necessary working conditions for an investigator, a prosecutor, an investigative judge and court, which is connected to criminal proceedings (Article 21). Internal regulations of a detention center of State Penitentiary Service of Ukraine, approved by Ministry of Justice of Ukraine of 14 June 2019, provide that prosecutor conducting supervision has a right to enter pre-trial detention centers ('SIZO') at any time. Upon an investigator's, prosecutor's or investigative judge's decision, written order to conduct criminal proceedings, medical forensic analysis in the territory of a pre-trial detention centers the administration is required to: provide premises; transfer of a detainee, convicted person to the requested premise and provide protection to them; ensure the access of persons involved in investigative actions to pre-trial detention centers. Law of Ukraine "On Prosecutor's Office" provides that a prosecutor while supervising the compliance with law during the execution of court decisions in criminal cases as well as during application of other coercive measures involving restriction of persons' freedoms, has a right, upon the presentation of a document certifying his or her position to enter at any time detention places, centers, pre-trial detention facilities, where persons serve their sentences, facilities where people are placed awaiting for application of compulsory medical or educational measures, and any other places to which persons where carried in order to draw up an administrative offence report or where persons are detained upon court or administrative body decision. Nonetheless, para. 10-1 of Order "On organization of prosecutor's activity of supervising the compliance with law during the execution of court decisions in criminal cases as well as during application of other coercive measures involving restriction of persons' freedoms" of 20 April 2016 obliges a prosecutor to immediately release illegally detained person (in case of absence of relevant court decision, decision of administrative body or other document prescribed by law or after 
the time limit prescribe by law or the decision has expired) kept in detention places, centers, pre-trial detention facilities, facilities where the coercive measure are applied, other places to which persons where carried in order to draw up an administrative offence report or where persons are detained upon court or administrative body decision.

However, despite these rules neither an investigator, or prosecutor who provides procedural guidance has any rights that would demonstrate that they have access 'to any other place where there are reasonable grounds to believe that the disappeared person may be present' as stated in Convention. The quoted provisions of legal acts of Ukraine fail to take into account situations of enforced disappearance.

Article 17 of Convention provides that no one shall be held in secret detention. Without prejudice to other international obligations of the State Party with regard to the deprivation of liberty, each State Party shall, in its legislation: a) establish the conditions under which orders of deprivation of liberty may be given; b) indicate those authorities authorized to order the deprivation of liberty; c) guarantee that any person deprived of liberty shall be held solely in officially recognized and supervised places of deprivation of liberty; d) guarantee that any person deprived of liberty shall be authorized to communicate with and be visited by his or her family, counsel or any other person of his or her choice, subject only to the conditions established by law, or, if he or she is a foreigner, to communicate with his or her consular authorities, in accordance with applicable international law; e) guarantee access by the competent and legally authorized authorities and institutions to the places where persons are deprived of liberty, if necessary with prior authorization from a judicial authority; f) guarantee that any person deprived of liberty or, in the case of a suspected enforced disappearance, since the person deprived of liberty is not able to exercise this right, any persons with a legitimate interest, such as relatives of the person deprived of liberty, their representatives or their counsel, shall, in all circumstances, be entitled to take proceedings before a court, in order that the court may decide without delay on the lawfulness of the deprivation of liberty and order the person's release if such deprivation of liberty is not lawful. In case of enforced disappearance, the domestic criminal procedural law has the mechanism provided for by Article 206 of CCP of Ukraine. Despite the fact that the article is in Chapter 18 - preventive measure, apprehension of a person, the content of the article, particularly the provision that each investigating judge whose territorial jurisdiction extends to a person committed to custody may issue a ruling by which orders any public authority or official to ensure respect for such person's right; whenever an 
investigating judge receives information from any sources whatsoever, which gives ground for a reasonable suspicion that within the court's territorial jurisdiction, there is a person who has been deprived of liberty without valid court's decision, or has not been released from custody after the payment of bail in accordance with the procedure laid down in the present Code, such judge is required to issue a ruling by which orders any public authority or official in whose custody the person is kept, to immediately bring this person to the investigating judge in view of verifying grounds for deprivation of liberty, - indicates that these rules can also be applied in case of enforced disappearance of a person that were placed in public or private custodial settings.

Within the context of application of appropriate measures to ensure the protection of a complainant, witnesses, relatives of the disappeared person and their defence counsel, as well as persons participating in the investigation as provided for by Article 12 of Convention, the following may be pointed out. CCP of Ukraine does not have the chapter dedicated to measures to ensure the safety. Instead, there is Law of Ukraine 'On ensuring the safety of persons participating in criminal proceedings' of 23 December 1993 that has the list of measures to ensure safety of persons which have a right to safety, bodies that ensure the safety, the procedure of initiation of adopting a decision on application of measure to ensure the safety and etc. Certain provisions of CCP of Ukraine, in particular regarding using video conference (Articles 232 and 336 of CCP of Ukraine), interrogation from another premise (Article 352 of CCP of Ukraine), also have the legal nature of measure to ensure the safety.

Article 10 of Convention provides that any State party in whose territory a person suspected of having committed an offence of enforced disappearance is present shall take him or her into custody or take such other legal measures as are necessary to ensure his or her presence. The custody and other legal measures shall be as provided for in the law of that State Party but may be maintained only for such time as is necessary to ensure the person's presence during criminal procedural actions. However, such wording is contrary to the presumption of achieving the aim - effectiveness of criminal proceedings - without application of measures to ensure criminal proceedings $^{3}$, among which is a custody as a preventive measure, as well as

\footnotetext{
${ }^{3}$ Hloviuk I. V. (2013) Prezumptsii y tiahar dokazuvannia u rozghliadi slidchym suddeiu klopotan pro zastosuvannia zakhodiv zabezpechennia kryminalnoho provadzhennia [Presumptions and burden of proof in considering motions on application of measures to ensure criminal proceedings by an investigative judge]. Yurydychnyi chasopys Yurydychnyi chasopys Natsionalnoi akademii vnutrishnikh sprav [Legal herald of National academy of internal affairs], no. 2, pp. 84-89.
} 
presumption of a person's freedom when applying Article 5 (c) of the Convention for the Protection of Human Rights and Fundamental Freedom $(\text { ECHR })^{4}$.

It should be noted that regarding enforced disappearance application of mechanisms provided for by Law of Ukraine 'On legal status of missing persons'. A missing person is an individual whose whereabouts are unknown at the time of submission of an application for a search by an applicant (Article 1 of the Law). The person is regarded missing from either the moment of the application on the fact of missing a person and his/her search was filed or upon court decision (Article 4 of the Law).

Article 5 of Law of Ukraine 'On legal status of missing persons' provides that the missing person has all the rights guaranteed by the Constitution of Ukraine as well as the right to comprehensive investigation into circumstances surrounding the missing person and clarification on his/her whereabouts. In fact, it is the reference to effective investigation, criteria of which were formulated by ECtHR in regard to Article 2 of ECHR. It is noteworthy that regarding a disappearance ECtHR stated that it is a distinct phenomenon, characterised by an ongoing situation of uncertainty and unaccountability in which there is a lack of information or even a deliberate concealment and obfuscation of what has occurred. This situation is very often drawn out over time, prolonging the torment of the victim's relatives. Thus, the procedural obligation will, potentially, persist as long as the fate of the person is unaccounted for; the ongoing failure to provide the requisite investigation will be regarded as a continuing violation. This is so, even where death may, eventually, be presumed (see cases of 'Varnava and Others v. Turkey', § 148 and 'Aslakhanova and Others v. Russia', § 122).

According to Article 2 of ECHR, the essential purpose of effective investigation is to secure the effective implementation of the domestic laws which protect the right to life. The form of investigation that will achieve this purpose may vary in different circumstances. However, whatever mode is employed, the authorities must act of their own motion once the matter has come to their attention. They cannot leave it to the initiative of the next of kin either to lodge a formal complaint or to take responsibility for the

${ }^{4}$ Zavtur V. A. (2018) Prezumptsiia svobody osoby pry zastosuvanni punktu «S» statti 5 Konventsii pro zakhyst prav liudyny i osnovopolozhnykh svobod: praktyka Yevropeiskoho sudu z prav liudyny i natsionalnyi kontekst [Presumption of a person's freedom in application of Article 5 (c) of Convention for the Protection of Human Rights and Fundamental Freedom: case-law of European Court of Human Rights and domestic context]. Proceedings of the Praktyka Yevropeiskoho sudu z prav liudyny v diialnosti orhaniv prokuratury i sudu: vyklyky ta perspektyvy : mater. I Mizhnar. nauk.-prakt. konf. (Ukraine, Kyiv, June 13, 2018), Kyiv: National Prosecution Academy of Ukraine, pp.81-85. 
conduct of any investigatory procedure (see case of 'Muravskaya v. Ukraine', § 41). Thus, regarding a disappearance the state has an obligation to react to the fact regardless of whether a complaint has been lodged. Article 18 of the Law of Ukraine 'On legal status of missing persons' stipulates that an application for a search for a missing person shall be lodged to the appropriate local agency of the National police of Ukraine. The application for a search for a missing person may be lodged by a relative, a representative of a military formation, public authority, local government, citizen's association or any other person has learned about the fact of missing. The application may be lodged by the Commission on Missing Persons in Special Circumstances if persons provided in paragraph two of the current part applied to the commission with the notification on a missing person. Which raises several issues. First, the only legal fact provided by law to search a missing person is an application which raises a question whether it is possible to initiate the search by the National police when information about the missing persons was received from other sources. The answer must be positive as it stems from positive obligations of the state under Article 2 of ECHR, however it is not directly stipulated in the Law of Ukraine 'On legal status of missing persons'. Besides that, the person in question obtains the status of a missing person from the moment of the application on the fact of missing a person and his/her search was filed or upon the court's decision. These provisions, again, actualize the issue of ex officio authority for carrying out the search.

Secondly, the Law of Ukraine 'On legal status of missing persons' refers to submission of an application 'to the appropriate local agency of the National police of Ukraine', however how the 'appropriateness' of local agency of the National police of Ukraine should be addressed (depending on the place of disappearance, the last place of that person's place of residence or whereabouts, place of residence of his/her relatives, location of a military formation, location of public authority or local government, location of the Commission on Missing Persons in Special Circumstances etc.) is missing in the law. Effective investigation should not have such formal limitations, thus it more logical to stipulate that the application may be lodged to any local agency of the National police of Ukraine ${ }^{5}$.

${ }^{5}$ Hloviuk I. V. (2019) Rozsliduvannia faktiv znyknennia bezvisty (u konteksti torhivli liudmy) [Investigation of facts of disappearance (within the context of human trafficking)]. Proceedings of the Protydiia nezakonnii mihratsii ta torhivli liudmy: materialy III Mizhnarodnoho naukovo-praktychnoho sympoziumu (Ukraine, Ivano-Frankivsk, April 12-13, 2019), Ivano-Frankivsk: Editorial and Publishing Department of King Danylo University, pp.31-34. 


\section{Issues of court proceedings and compensation for damage}

Recommendation No. R (97) 13 of the Committee of Ministers of the Council of Europe to Member States concerning intimidation of witnesses and the rights of the defence provides that while respecting the rights of the defence, witnesses should be provided with alternative methods of giving evidence which protect them from intimidation resulting from face to face confrontation with the accused, for example by allowing witnesses to give evidence in a separate room. The following measures should, inter alia, be considered: recording by audiovisual means statements made by witnesses during pre-trial examination; using pre-trial statements given before a judicial authority as evidence in court when it is not possible for witnesses to appear before the court or when appearing in court might result in great and actual danger to the life and security of witnesses, their relatives or other persons close to them; revealing the identity of witnesses at the latest possible stage of the proceedings and/or releasing only selected details; excluding the media and/or the public from all or part of the trial. Is should be noted that not all of these recommendations can be realized under current $\mathrm{CCP}$ of Ukraine, including the proceedings regarding enforced disappearance. Recorded by audiovisual means statements made by witnesses during pre-trial examination can be used, however according to Articles 23 and 95 of CCP of Ukraine the recording cannot be deemed as a testimony for a court and be used when delivering a judgement. Use of testimonies, given to a court during pre-trial investigation, is possible in court if appearing of witnesses in a court is impossible or when appearing in a court might result in great and actual danger to the life and security of witnesses, their relatives or other persons close to them, in case of deposition of evidence is admissible, however when filing a motion to an investigative judge pursuant to Article 225 of CCP of Ukraine an investigator should indicate what circumstances demonstrate the existence of danger to witnesses' or victims' life and health. Nonetheless, in case of deposition of evidence the court has a right to question the victim, the witness that were questioned according to the rules of the current article, for instance in case the interrogation was conducted in the absence of the defence party or where there is a need to clarify testimonies or take testimonies regarding any circumstances that were not clarified as a result of interrogations in the course of pre-trial investigation (Article 225 Para. 4); considering these provisions the court may make the decision proprio motu.

As regards interrogation in a court, considering the sensitive nature of the issue of victims' and witnesses' questioning in the proceedings, it should be noted that it is difficult to model proposals on amendments to criminal 
procedural legislation regarding the victim's and the witness's possibility not to testify in court, but to use deposited testimonies or testimonies recorded in video or audio. This is because everyone charged with a criminal offence has a right to examine or have examined witnesses against him and to obtain the attendance and examination of witnesses on his behalf under the same conditions as witnesses against him (Article 6 of ECHR), and the notion of a witness has an autonomous meaning in the case-law of ECtHR and applies to a victim. Although, ECtHR does not object to the possibility of using testimony of an absent witness, however, it imposes certain limitations. For instance, in case of 'Al-Khawaja and Tahery v. the United Kingdom' ECHR has formulated the test to decide whether there was a violation of the Article $6 \S \S 1$ and 3 (d) of ECHR. Article $6 \S 1$ of ECHR together with Article $6 \S 3$ (d) of ECHR enshrines a principle that, before an accused can be convicted, all evidence against him must normally be produced in his presence at a public hearing with a view to adversarial argument. Exceptions to this principle are possible but must not infringe the rights of the defence, which, as a rule, require that the accused should be given an adequate and proper opportunity to challenge and question a witness against him, either when that witness makes his statement or at a later stage of proceedings. There are two requirements which follow from the above general principle. Firstly, there must be a good reason for the non-attendance of a witness. The death or a witness's non-attendance due to the fear, whereas the accused person or those acting on his/her behalf are accountable for that, is regarded as good reasons as in the latter case the accused person is deemed as one who waived his/her rights guaranteed by Article $6 \S 3$ (d). Before a witness can be excused from testifying on grounds of fear, the trial court must be satisfied that all available alternatives, such as witness anonymity and other special measures, would be inappropriate or impracticable. Secondly, when a conviction is based solely or to a decisive degree on depositions that have been made by a person whom the accused has had no opportunity to examine or to have examined, whether during the investigation or at the trial, the rights of the defence may be restricted to an extent that is incompatible with the guarantees provided by Article 6 (the so-called "sole or decisive rule"). However, the rule is not absolute and cannot be applied in an inflexible manner while ignoring entirely the specificities of the particular legal system concerned as it would transform the rule into a blunt and indiscriminate instrument that runs counter to the traditional way in which ECtHR approaches the issue of the overall fairness of the proceedings, namely to weigh in the balance the competing interests of the defence, the victim, and witnesses, and the public interest in the effective administration 
of justice. Therefore, where a hearsay statement is the sole or decisive evidence against a defendant, its admission as evidence will not automatically result in a breach of Article $6 \S 1$ of ECHR. At the same time, where a conviction is based solely or decisively on the evidence of absent witnesses, ECtHR must subject the proceedings to the most searching scrutiny. Because of the dangers of the admission of such evidence, it would require sufficient counterbalancing factors, including the existence of strong procedural safeguards. As to the question whether these guarantees were applied in practice, ECHR has considered three issues in each case: whether it was necessary to admit the witness statements of absent witnesses; whether their untested evidence was the sole or decisive basis for each applicant's conviction; whether there were sufficient counterbalancing factors including strong procedural safeguards to ensure that each trial, judged as a whole, was fair ${ }^{6}$.

Consequently, while applying relevant rules of CCP of Ukraine, particularly regarding court's questioning of victims, once the deposition of testimonies has been used, re-examination of victims, witnesses, examination of victims, witnesses that are subject to measures of security, so that the overall fairness of trial and legality of court decision would not be questioned later the mode of video conference should be used, to interrogate victims, witnesses using technical means from other premises, including outside the premises of court, or in other way making his identification impossible, and ensures parties to criminal proceedings the possibility to ask questions and hear answers thereto in conditions making his identification impossible. Article 352 Para. 9 of CCP of Ukraine provides that before such ruling is made the court shall be required to establish whether the parties to criminal proceedings have any objections to the examination of a witness in the conditions making his identification impossible and, if found founded, decline to have the witness examined under the rules of this paragraph. While making a ruling the court has an obligation to consider legal positions laid down by ECHR, inter alia, in cases of 'Al-Khawaja and Tahery v. the United Kingdom', 'Schatschaschwili v. Germany', 'Boyets v. Ukraine', 'Murtazaliyeva v. Russia'. For example, the Court reiterates that the guarantees in paragraph 3 (d) of Article 6 are specific aspects of the right to a fair hearing set forth in paragraph 1 of this provision which must be taken into account in any assessment of the fairness of proceedings. According to

6 Drozdov O., Drozdova O. (2016) Ohliad sprav shchodo inozemnykh krain, rozghlianutykh YeSPL protiahom bereznia 2016 roku [Review of the cases regarding foreign states decided by ECtHR during March 2016]. Visnyk Natsionalnoi asotsiatsii advokativ Ukrainy [Herald of Ukrainian Bar Association], vol. 24, no. 6, pp. 46-48. 
the Court's case-law, the use in evidence of statements obtained at the police inquiry and judicial investigation stages is not in itself inconsistent with the provisions cited above, provided that the rights of the defence have been respected. In principle, these rules require that the defendant be given an adequate and proper opportunity to challenge and question a witness against him, either when he makes his statements or at a later stage of proceedings. In Al-Khawaja and Tahery, the Grand Chamber clarified the principles to be applied when a witness does not attend a public trial. Those principles may be summarised as follows: (i) the Court should first examine the preliminary question of whether there was a good reason for admitting the evidence of an absent witness, keeping in mind that witnesses should as a general rule give evidence during the trial and that all reasonable efforts should be made to secure their attendance; (ii) typical reasons for non-attendance are, as in the case of Al-Khawaja and Tahery, the death of the witness or the fear of retaliation. There are, however, other legitimate reasons why a witness may not attend a trial; (iii) when a witness has not been examined at any prior stage of the proceedings, allowing the admission of a witness statement in lieu of live evidence at trial must be a measure of last resort; (iv) the admission as evidence of the statements of absent witnesses results in a potential disadvantage for the defendant, who, in principle, in a criminal trial should have an effective opportunity to challenge the evidence against him. In particular, he should be able to test the truthfulness and reliability of the evidence given by the witnesses, by having them orally examined in his presence, either at the time the witness was making the statement or at some later stage of the proceedings; (v) according to the "sole or decisive rule", if the conviction of a defendant is solely or mainly based on evidence provided by witnesses whom the accused is unable to question at any stage of the proceedings, his defence rights are unduly restricted; (vi) in this context, the word "decisive" should be narrowly understood as indicating evidence of such significance or importance as is likely to be determinative of the outcome of the case. Where the untested evidence of a witness is supported by other corroborative evidence, the assessment of whether it is decisive will depend on the strength of the supportive evidence: the stronger the other incriminating evidence, the less likely that the evidence of the absent witness will be treated as decisive; (vii) however, as Article $6 \S 3$ of the Convention should be interpreted in the context of an overall examination of the fairness of the proceedings, the sole or decisive rule should not be applied in an inflexible manner; (viii) in particular, where a hearsay statement is the sole or decisive evidence against a defendant, its admission as evidence will not automatically result in a breach of Article $6 \S 1$. At the same time, where a 
conviction is based solely or decisively on the evidence of absent witnesses, the Court must subject the proceedings to the most searching scrutiny. Because of the dangers of the admission of such evidence, it would constitute a very important factor to balance in the scales and one which would require sufficient counterbalancing factors, including the existence of strong procedural safeguards. The question in each case is whether there are sufficient counterbalancing factors in place, including measures that permit a fair and proper assessment of the reliability of that evidence to take place. This would permit a conviction to be based on such evidence only if it is sufficiently reliable given its importance to the case. Those principles have been further clarified in the case of Schatschaschwili v. Germany ([GC], no. 9154/10, §§ 110-31, ECHR 2015) in which the Grand Chamber confirmed that the absence of good reason for the non-attendance of a witness could not, of itself, be conclusive of the lack of fairness of a trial, although it remained a very important factor to be weighed in the balance when assessing the overall fairness, and one which might tip the balance in favour of finding a breach of Article $6 \S \S 1$ and 3 (d). Furthermore, given that its concern was to ascertain whether the proceedings as a whole were fair, the Court should not only review the existence of sufficient counterbalancing factors in cases where the evidence of the absent witness was the sole or the decisive basis for the applicant's conviction, but also in cases where it found it unclear whether the evidence in question was sole or decisive but nevertheless was satisfied that it carried significant weight and its admission might have handicapped the defence. The extent of the counterbalancing factors necessary in order for a trial to be considered fair would depend on the weight of the evidence of the absent witness. The more important that evidence, the more weight the counterbalancing factors would have to carry in order for the proceedings as a whole to be considered fair ('Boyets v. Ukraine', paras. 74-76).

At the same time, consideration should be given to one more issue of the procedure of examination of a witness with the use of technical means from another premise, including outside court's building, or in other way making his identification impossible, and ensures parties to criminal proceedings the possibility to ask questions and hear answers thereto. Article 352 Para. 9 of $\mathrm{CCP}$ of Ukraine provides the following: In exceptional cases with a view to ensure security of a witness to be examined, the court, proprio motu or upon the motion of parties to criminal proceedings or of the witness himself, passes a reasoned ruling to examine the witness concerned with the use of technical means from another premise, including outside court's building, or in other way making his identification impossible, and ensures parties to 
criminal proceedings the possibility to ask questions and hear answers thereto. If there is a danger that witness's voice can be identified, examination may be accompanied by acoustic disturbance. Before such ruling is made the court shall be required to establish whether the parties to criminal proceedings have any objections to the examination of a witness in the conditions making his identification impossible and, if found founded, decline to have the witness examined under the rules of this paragraph. However, these rules cannot be applied if no security measure were taken to the witness or the victim within criminal proceedings under Law of Ukraine 'On ensuring the safety of persons participating in criminal proceedings'. Additionally, questioning under Article 352 Para. 9 of CCP of Ukraine indicates that the procedure can be used solely for preventing witness's, victim's identification; thus, if the witness or the victim are identified the procedure cannot be used.

According to Article 24 of Convention, each State party shall ensure in its legal system that the victims of enforced disappearance have the right to obtain reparation and prompt, fair and adequate compensation. Article 1177 of Civil Code of Ukraine provides that the damage caused to the victim by the offence is to be compensated by the State Budget of Ukraine in cases and according to the procedure stipulated by law. However, the rule is of a declarative nature as, to date, no special law has been adopted. When the law will be adopted and how it will regulate the specificities of compensation of damage caused by enforced disappearance cannot be foreseen. Thus, the provision enshrined in Article 24 of Convention has not been implemented in the current legislation.

\section{CONCLUSIONS}

Therefore, the analysis of the current criminal procedural and civil law demonstrates that current provisions are not entirely appropriate to the specificities of investigation of enforced disappearance, and thus, issues of implementing provisions of Convention into domestic law will arise.

Consequently, there is a need for amendments and additions to the current criminal procedural law regarding the abovementioned issues and taking into account the specifics of criminal proceedings regarding enforced entrapment.

Given that enforced disappearance is considered to be the arrest, detention, abduction or any other form of deprivation of liberty by agents of the state including by a foreign one, followed by a refusal to acknowledge the deprivation of liberty or by concealment of the fate or whereabouts of the disappeared person, there is the need to clarify the jurisdiction and to 
stipulate that investigation of such facts shall be conducted only by investigators of State Bureau of Investigation.

It is inappropriate for cases of enforced disappearance to be limited in application of covert investigative (search) actions, except for collecting information from electronic information systems or parts thereof the access to which is not restricted by the system's owner, possessor or keeper or is not related to circumventing a system of logical protection and establishing the location of a radio electronic device (Article 146-1 Para. 1 of CC of Ukraine) and restriction to conduct covert investigative (search) actions (namely establishing the location of a radio electronic device (Article 268 Para. 4 of CCP of Ukraine); surveillance of an individual (Article 269 Para. 3 of CCP of Ukraine) prior to an investigative judge's ruling that requires revision, inter alia, of provision of $\mathrm{CC}$ of Ukraine in regard to the sanction of the article.

It is important to set the clear regulatory framework for access to the public or private custodial settings by investigators and prosecutors who provide procedural guidance in course of the investigation of offences provided for by Article 146-1 of CC of Ukraine.

Law of Ukraine 'On the legal status of missing persons' has to be amended regarding the possibility of initiation of search by bodies of the National Police of Ukraine without territorial linkage to 'appropriate local agency of the National Police of Ukraine'.

It is necessary to develop a regulatory and law-enforcement mechanism of realization of Article 1177 of Civil Code of Ukraine which provides that the damage caused to the victim by the offence is to be compensated by the State Budget of Ukraine in cases and according to the procedure stipulated by law.

It is required to clarify the grounds of using the mode of video conference and an interrogation using technical means from other premises, including outside the premises of court, or in other way making his identification impossible, and ensures parties to criminal proceedings the possibility to ask questions and hear answers thereto; when deciding on the application of safety measures to a victim during an interrogation in conditions making his identification impossible the test for finding violations of Article $6 \S 3$ (d) of ECHR developed by ECtHR in the case of 'AlKhawaja and Tahery v. the United Kingdom' should be applied.

\section{SUMMARY}

The article deals with criminal proceedings regarding enforced disappearance in Ukraine. The goal of the research is to identify issues of 
ensuring the provisions of Convention for the Protection of All Persons from Enforced Disappearance by procedural means of domestic legislation. The problems of pre-trial investigation and placement in public or private custodial settings, court proceedings and compensation for damage were discussed. The analysis of the current criminal procedural and civil law clearly demonstrates that current provisions are not entirely appropriate to the specificities of investigation of enforced disappearance, and thus, issues of implementing provisions of Convention for the Protection of All Persons from Enforced Disappearance into domestic law will arise. Consequently, there is a need for amendments and additions to the current criminal procedural law regarding abovementioned issues and taking into account the specifics of criminal proceedings regarding enforced entrapment. There is the need to clarify the jurisdiction and to stipulate that investigation of such facts shall be conducted only by investigators of State Bureau of Investigation. Also Law of Ukraine 'On the legal status of missing persons' has to be amended regarding the possibility of initiation of search by bodies of the National Police of Ukraine without territorial linkage to 'appropriate local agency of the National Police of Ukraine'; to clarify the grounds of using the mode of video conference and an interrogation using technical means from other premises, including outside the premises of court, or in other way making his identification impossible, and ensures parties to criminal proceedings the possibility to ask questions and hear answers thereto.

It is necessary to set the clear regulatory framework for access to the public or private custodial settings by investigators and prosecutors who provide procedural guidance in course of the investigation of offences provided for by Article 146-1 of CC of Ukraine; to develop a regulatory and law-enforcement mechanism of realization of Article 1177 of Civil Code of Ukraine which provides that the damage caused to the victim by the offence is to be compensated by the State Budget of Ukraine in cases and according to the procedure stipulated by law;.

\section{REFERENCES}

1. Babin B. (2019, February 24) Nasylnytski znyknennia v Ukraini. Pravovi deklaratsii ta realii viiny [Enforced disappearances in Ukraine. Legal declarations and realities of war]. Ukrainska Pravda. Retrieved from https://www.pravda.com.ua/columns/2019/02/24/7207525/ (accessed 16 October 2019).

2. Drozdov O., Drozdova O. (2016) Ohliad sprav shchodo inozemnykh krain, rozghlianutykh YeSPL protiahom bereznia 2016 roku [Review of the cases regarding foreign states decided by ECtHR during March 2016]. 
Visnyk Natsionalnoi asotsiatsii advokativ Ukrainy [Herald of Ukrainian Bar Association], vol. 24, no. 6, pp. 46-48.

3. Hloviuk I. V. (2013) Prezumptsii y tiahar dokazuvannia u rozghliadi slidchym suddeiu klopotan pro zastosuvannia zakhodiv zabezpechennia kryminalnoho provadzhennia [Presumptions and burden of proof in considering motions on application of measures to ensure criminal proceedings by an investigative judge]. Yurydychnyi chasopys Yurydychnyi chasopys Natsionalnoi akademii vnutrishnikh sprav [Legal herald of National academy of internal affairs], no. 2, pp. 84-89.

4. Hloviuk I. V. (2019) Rozsliduvannia faktiv znyknennia bezvisty (u konteksti torhivli liudmy) [Investigation of facts of disappearance (within the context of human trafficking)]. Proceedings of the Protydiia nezakonnii mihratsii ta torhivli liudmy: materialy III Mizhnarodnoho naukovopraktychnoho sympoziumu (Ukraine, Ivano-Frankivsk, April 12-13, 2019), Ivano-Frankivsk: Editorial and Publishing Department of King Danylo University, pp.31-34.

5. Khrystova H. Pro pozytyvni zoboviazannia derzhavy stosovno prav liudyny $\mathrm{v}$ umovakh zbroinoho konfliktu ta yoho naslidkiv [On positive obligations of the state regarding human rights in conditions of armed conflict and its consequences]. Retrieved from https://rm.coe.int/native/ $168072 \mathrm{~b} 3 \mathrm{cf}$ (accessed 16 October 2019).

6. Zavtur V. A. (2018) Prezumptsiia svobody osoby pry zastosuvanni punktu «S» statti 5 Konventsii pro zakhyst prav liudyny i osnovopolozhnykh svobod: praktyka Yevropeiskoho sudu z prav liudyny i natsionalnyi kontekst [Presumption of a person's freedom in application of Article 5 (c) of Convention for the Protection of Human Rights and Fundamental Freedom: case-law of European Court of Human Rights and domestic context]. Proceedings of the Praktyka Yevropeiskoho sudu z prav liudyny v diialnosti orhaniv prokuratury $i$ sudu: vyklyky ta perspektyvy : mater. I Mizhnar. nauk.-prakt. konf. (Ukraine, Kyiv, June 13, 2018), Kyiv: National Prosecution Academy of Ukraine, pp.81-85.

\section{Information about the author: Iryna Hloviuk,}

Doctor of Law, Associate Professor, Head of the Department of Criminal Procedure, National University "Odesa Law Academy”, 23, Fontanska road, Odesa, Ukraine ORCID ID: orcid.org/0000-0002-5685-3702 
DOI https://doi.org/10.36059/978-966-397-159-9/69-88

\section{ADMINISTRATIVE AND LEGAL REGULATION PECULIARITIES OF THE MANAGING ACTIVITIES OF THE UKRAINIAN STATE BORDER GUARD BODIES (UNITS) CHIEFS}

\section{Vadym Polovnikov}

\section{INTRODUCTION}

In the context of administrative reform, optimization of the system of central executive bodies, other structural and political transformations in Ukraine, the issues of improvement of administrative and legal regulation of public administration and, directly, management in such specific field as safeguarding and protection of state border of Ukraine (hereinafter - SBU) are acute. The current state of managing activities in this area needs improvement. The content of managing activities of the state border guard bodies (units) chiefs of the State Border Guard Service of Ukraine (hereinafter - SBGSU) changes significantly in the modern conditions, has certain peculiarities and its qualitative implementation is not possible without proper administrative and legal regulation. Accordingly, these issues are extremely relevant today.

The scientific and theoretical basis for this work's writing was made by scientific works of such domestic and foreign scientists as: L.M. Albastova, G.V. Atamanchuk, E.M. Babosov, Y.P. Bytyak, E.B. Dorin, V.V. Zalozh, V.V. Zui, V.G. Ignatov, A.P. Kamyshnikov, S.V. Karpenko, S.M. Knyazev, L.V. Koval, A.M. Kolodiy, V.K. Kolpakov, A. T. Komziuk, V. V. Kopeychikov, A. G. Korchenko, B. M. Lazarev, S. L. Lysenkov, V. A. Lipkan, M. M. Litvin, V. Y. Malinovsky, V.I. Makhinin, M.I. Melnyk, V.M. Priymak, V.E. Sevryugin, O.F.Skakun, V.P. Sladkevich, M.I. Khavroniuk, A.D. Cherniavskiy, Y.S. Shemshuchenko, A.S. Shcherbakov, and others.

\section{General characteristics of the administrative} and legal regulation peculiarities of the managing activities of the Ukrainian state border guard bodies (units) chiefs

Characterizing the peculiarities of administrative and legal regulation of the managing activities of the state border guard bodies (units) chiefs of the SBGSU, we proceed from the fact that the principle of the rule of law is recognized in Ukraine. Ukraine's Constitution has the highest legal force. 
Laws and other legal acts are adopted based on Ukraine's Constitution and must comply with it. Ukraine's Constitution norms are direct action norms (Article 8 of the Constitution of Ukraine) ${ }^{1}$.

Ukraine's Constitutional court in its decisions has repeatedly noted that according to Article 19 of Ukraine's Constitution, all public authorities are obliged to act only on the basis and within the powers and in the manner provided by Ukraine's laws and Constitution. Decision of June 17, 2010 No. 17-rp / 2010 stated that "one of the rules of law's elements is the principle of legal certainty, which states that fundamental human rights' restriction and the implementation of these restrictions in practice are permissible only in case of ensuring of predictability of legal norms' application, established by such restrictions. That is, any right's restriction must be based on criteria which enable a person to separate lawful behavior from unlawful one, to foresee this conduct's legal consequences" (paragraph 3, subparagraph 3.1, motivation part article 3$)^{2}$.

The same Decision refers to another Decision of Ukraine's Constitutional court No. 5-rp / 2005 dated September 22, 2005, which states that legal rule's requirements of certainty, clarity, and ambiguity follows from the constitutional principles of equality and justice, since otherwise cannot provide it the same application, does not exclude the unrestricted interpretation in law enforcement practice and inevitably leads to arbitrariness (paragraph 5, subparagraph, 5.4, motivation part article 5) ${ }^{3}$. This directly applies to the administrative and legal regulation of internal and external managing activities of the SBGSU state border guard bodies (units) chiefs.

Considering this issue, it should be emphasized that administrative and legal regulation is considered as one of the managing methods.

According to the Legal Encyclopedia, the method of legal regulation is a way of legal norms influencing public relations. It is characterized by the following features: applies only to legal provisions; ensures the unity of legal regulation; is guaranteed in cases of necessity utilizing state coercion; is one of the criteria for the division of law in the branches. Legal regulation methods are divided into imperative and dispositive. The imperative method implies an overbearing influence on the members of public relations without

\footnotetext{
${ }^{1}$ Konstitutsia Ukrayini: zakon Ukrayini № 254к/96-VR [Constitution of Ukraine]. 28 June 1996. Data onovlennia: 21.02.2019. URL: https://zakon2.rada.gov.ua/laws/main/254к/96-вр (date of request: 31.10.2019). [In Ukrainian]

${ }^{2}$ Rishenniya Konstitutsiynogo sudu Ukrainy №. 17-rp / 2010 [Judgment of the Constitutional Court of Ukraine]. 29 June 2010. URL: https://zakon.rada.gov.ua/laws/show/ v017p710-10 (date of request: 31.10.2019). [In Ukrainian]

${ }^{3}$ Rishenniya Konstitutsiynogo sudu Ukrainy №. 17-rp / 2010 [Judgment of the Constitutional Court of Ukraine]. 29 June 2010. URL: https://zakon.rada.gov.ua/laws/show/ v017p710-10 (date of request: 31.10.2019). [In Ukrainian]
} 
the right to choose (e.g., in criminal and administrative law). The dispositive method, on the contrary, provides options of behavior of public relations participants as equal parties (it is applied, in particular, in civil law). There are also other classifications of legal regulation methods in the legal literature: general permits and special permits; subordination and coordination; education, encouragement, and coercion. This testifies to the complex nature of this legal category, which often appears not in its pure form, but as a set of methods of law rules implementing ${ }^{4}$.

According to E.M. Babosov, following the classical tradition, which originates in the writings of M. Weber, there are relations of dependence, power, submission, and domination, which are decisive in the management system. Since between $50 \%$ and $90 \%$ of their working time, people involved in management spend on communication with their subordinates or chiefs, it is important to find appropriate models and methods of communication, thanks to which you can develop and implement optimal solutions, namely those that at the same time and in the best way ensure the achievement of two different goal groups, oriented by the actions of two different, quite often social rivals - individuals, society and the state ${ }^{5}$.

Ukraine's state border guard bodies (units) are included in the SBGSU system, which is known to be a complex, multilevel and integrated dynamically developing system. The management ensures its preservation and further development, streamlining its structure, interaction with other state bodies, public organizations, population and activities' purpose (goals) achievement.

According to the Interpretative Dictionaries of the modern Ukrainian language, management - action with meaning "to manage" means: 1. To direct the activity, the work of someone, something; to lead someone, something; to guide. 2. To direct the course, the course of a process, to influence the development, the state of something ${ }^{6,7}$. The content of management as a social function is manifested in the organizing activity, which is achieved through unification, adjustment, regulation, coordination,

\footnotetext{
${ }^{4}$ Yuridichna Ensiklopediya [Legal Encyclopedia] / red. Y.S.Shemshuchenko [ta insh.] / NAN Ukrainy, V.M. Koretsky Institut derzavi i prava. Kyiv: vid. Ukrainska entsiklopediya im.M.P. Bazhan, Toml. 3: K-M. 2001. P. 617. [In Ukrainian]

${ }^{5}$ Babosov, E. M. Sotsyolohyya upravleniya : posobye dlya studentov vuzov [Sociology of management] / E. M. Babosov. 6-e izd., pererab. y dop. Mynsk : TetraSystems, 2010. S. 3-4.[In Ukrainian]

${ }^{6}$ Velykyy tlumachniy slovnyk suchasnoyi ukrayins'koyi movy [The Big Interpretive Dictionary of Modern Ukrainian] / Uklad. i holov. red. V. T. Busel. Kyiv; Irpin': VTF «Perun», 2009. S. 1511. [In Ukrainian]

${ }^{7}$ Noviy tlumachniy slovnyk ukrayins'koyi movy : u 3 t. 200000 sliv [New interpretative dictionary of the Ukrainian language] / [uklad. Vasyl' Yaremenko, Oksana Slipushko]. vyd. 2-e, vypr., t. 3 P-YA. Kyiv : AKONIT, 2008. S. 624-625. [In Ukrainian]
} 
and control. The organizing function of social management is inextricably linked to power-organizing activity. There is no society as a complex selfgoverning system without management, as there is no social management without the will, power, and authority. The government acts as a functional property, social organization immanent quality, which is realized through social management, should be carried out based on the subordination and unity of will of joint activity participants. In this context, management is primarily a state's organizing activity, the main feature of which is power. This type of management is called public administration. Only public administration ensures the functioning and development of society as a whole ${ }^{8}$.

Legal regulation in the theory of law refers to the state's specific activity, its bodies, and officials on the regulation of social relations by establishing legal norms and making, in the necessary cases, individually-regulatory decisions following these norms on legally significant issues arising in the process of such relations. Legal regulation is functional, managerial.

Administrative and legal regulation of Ukrainian state border guard bodies (units) chiefs' managing activities is a consolidation at the level of legal acts that proclaim legal norms, management procedures. Such regulation is at Ukraine's laws and by-laws level.

Classification according to the constituent entities is a common differentiation of legal acts. Thus, the Verkhovna Rada of Ukraine, according to Ukraine's Constitution Art. 91, adopts laws, decrees and other acts (resolutions, declarations, appeals, statements). The President of Ukraine, according to Ukraine's Constitution Art. 106, issues decrees and orders. Ukraine's executive bodies issue the following legal acts: the Cabinet of Ministers, following Ukraine's Constitution Art. 117, - resolutions and orders; other executive bodies (departments and agencies) - orders. By external form, the main legal acts in Ukraine are the Constitution, laws, decrees, decisions, orders, etc.

Ukraine's current legislation does not define the term «legal act». In the legal and specialized literature, there is also no consensus on the attribution to the legal bases in our case of managing activities of departmental orders, instructions, and other official regulations. The author of this study is an adherent of the view that all departmental legal acts do not create legal norms in the field of management, but determine the methodology and tactics of its implementation, the mechanism, and process of management,

\footnotetext{
${ }^{8}$ Yuridichna Ensiklopediya [Legal Encyclopedia] / red. Y.S.Shemshuchenko [ta insh.] / NAN Ukrainy, V.M. Koretsky Institut derzavi i prava. Kyiv: vid. Ukrainska enciklopedia im.r M.P. Bazhan, Tom.T. 6: T-Y. 2004, pp. 218-219. [In Ukrainian]
} 
principles and other provisions that are mandatory for management. In this case, we must proceed from the requirements of the Constitution's Art. 8, which provides that the rule of law applies in Ukraine since laws and other legal acts are adopted based on the Constitution and must comply with it.

Given the above, any body's leader's management activities' administrative and legal regulations are constituted by legal acts - official documents, which are created by state's competent authorities and contain mandatory legal norms (rules of conduct). They are the result of competent entities' activities, which called law-making - activities aimed at creating, amending or repealing regulations.

Unfortunately, legislative practice and technology in Ukraine do not fully implement the principle of legal certainty in terms of detailing management activity's procedures at the level of laws and their content, as a rule, is declarative, which leads to different interpretations and understanding of these rule's contents.

Forming a general concept of legislation, taking into account the specifics of management, the legislator abandoned the detailed legal regulation of all necessary management procedures and legal relations directly at the level of legislative acts. The current legislation only includes regulations of a general nature, revealing only the basic features of individual procedures. To specify their essence and to establish clear procedural rules, the legislator envisaged the possibility of issuing relevant departmental and interagency subordinate legal acts by the Administration of the SBGSU.

Regarding the legal acts that form the basis of administrative and legal regulation (legal basis) of the managing activities of the SBGSU state border guard bodies (units) chiefs, their number is quite large. Such acts define the general and individual competence (functions, duties, and rights) of the SBGSU body's (unit's) personnel in carrying out official (including management) activity, its social and legal status, protection, responsibility, etc.

That is, the legal regulation of the SBGSU state border guard bodies (units) chiefs managing activities is constituted by legal acts that can be divided into the following groups: 1) Ukraine's Constitution and laws; 2) Ukraine's Verkhovna Rada resolutions; 3) Ukraine's President's decrees and orders; 4) Ukraine's Cabinet of Ministers' resolutions and orders; 5) Orders of the Ministry of Interior and Administration of the SBGSU, SBGSU governing bodies' orders.

Constitution of Ukraine and laws determine the general principles of management, the status of SBGSU and its credentials. Each of these laws regulates certain social relations groups that arise in the course of 
management and in connection with it, in the course of professional activity, interaction, international cooperation, control, supervision, etc. Concepts, strategies, and programs for the development of the SBGSU, its bodies (units) determine the direction of management for the future. Regulations on the bodies (units) of the SBGSU determine their legal status, credentials of these bodies' (units) chiefs. The Orders approving the Instructions (lists, procedures), determine the order of activity, specify the legal norms, establish clear rules, administrative procedures in the activities of the chiefs and other officials of the bodies (units) of the SBGSU.

According to the laws of management, any organization exists and operates through its leadership. It is the leader who develops the management strategy, consolidates the efforts of his subordinates to achieve the goals and accomplish important tasks, which, in turn, is reflected in the preparation and adoption of appropriate management decisions.

The legal encyclopedia defines a management decision as a key act of the management process, which in its essence is the order of the managing entity (management entity) to a managed object (management object) and is subject to the mandatory implementation of the latter. It is a deliberate, willful, powerful act of organizing influence, which expresses the management entity's intention to object's desired functioning, contains a certain model of its actions aimed at achieving the expected result. The management decision must be scientifically sound, timely, competent, lawful, consistent, realistic to implement ${ }^{9}$.

When executing decisions, administrative (organizational and administrative) methods are generally used in combination with other forms, means, and activity methods. The important role at this stage is played by the discipline, observance of law. The managerial activity of the leader is of particular importance in such hierarchical structures as the SBGSU, built on the principle of unity.

SBGSU body's chief should be considered an official, vested with administrative authority, entrusted with the legal acts carrying out organizational, administrative, representative and other functions (professional, control, analytical, educational), given the right to make the most important administrative decisions on all areas of activities and the application of disciplinary influence measures in order to effectively fulfill operative and service activities' (hereinafter - OSA) tasks by the subordinate.

\footnotetext{
${ }^{9}$ Yuridichna Ensiklopediya [Legal Encyclopedia] / red. Y.S.Shemshuchenko [ta insh.] / NAN Ukrainy, V.M. Koretsky Institut derzavi i prava. Kyiv: vid. Ukrainska enciklopedia im.r M.P. Bazhan, Tom.T. 6: T-Y. 2004, P. 219-220. [In Ukrainian]
} 
The chief's of the body (unit) OSA content is reduced to performing these functions and, as practice shows, the multi-purpose, multifaceted and multifunctional nature of the SBGSU activity places high demands on the level of organizational skill of the chief, which is materialized in his managerial work. Characterizing the content of his managing activities, it must be assumed that he currently bears full responsibility for the organization of services and units, logistics and human resources, compliance with the discipline and legality, etc. It is the chief of the body (unit) of the SBGSU who plays the main role in the process of external administrative and internal administrative (organizational) activity. Also, he is a military official who manages the military body (unit).

The main content of the OSA management process in the SBGSU is to carry out a direct targeted influence of the chief on the body (unit) through the appropriate mechanism. In the process of such influence, the goals, tasks, functions, principles, and methods that make up the content of the management mechanism are practically realized; performing management functions complex of methods (planning, organization, coordination, control and motivation) is used; management decision making; management of functional subsystems (personnel, resources, finances, etc.). During the OSA, the military personnel and employees of the SBGSU have organizational relations, which are reflected in vertical (subordination) and horizontal (coordination) relations.

The body's (unit's) chief of the SBGSU is a special subject of management activities, which he organizes, carries out and at the same time controls the implementation of the management process regulation instructions. The administrative and legal status of an official originates from the moment of his replacement. His position defines the range of official authority and requirements for the person's official conduct. In case of violation of legal norms by body's (unit's) chief, depending on the type and meaning of responsibility, he may be prosecuted as a criminal, administrative, disciplinary, civil and material liability. Ignorance of law's requirements does not release from liability. The officials' legal responsibility is the result of their negligent performance or failure to exercise their official credentials. Officials as holders of legal authority are a special subject of all legal responsibility types.

In accordance with the decision of the National Security and Defense Council of May 6, 2015, "On the National Security Strategy of Ukraine", the reform and development of the intelligence, counterintelligence and law enforcement agencies of Ukraine (Part 4.4) should be carried out on the rule of law basis, patriotism, competence, deportation, appropriate 
demilitarization, coordination and interaction, division of tasks and elimination of functions duplication, democratic civil control and transparency. According to the final provisions of the Strategy, it is a binding document and a basis for the development of other strategic planning documents in the field of national security - sectorial strategies, as well as state programs for the development of the security and defense sector bodies ${ }^{10}$.

Scientists and practices have repeatedly drawn attention to the specifics of the state border guard bodies' activities, and in Art. 2 of the Law of Ukraine «On State Protection of Court and Law Enforcement Employees» in 1993 these bodies were called law enforcement for the first time. This view was later supported by scientists.

Granting the SBGSU the right to use coercion as one of external administrative activities methods determines its position's peculiarities in Ukraine's system of executive bodies. It is, in fact, a «law-enforced» body ${ }^{11}$. Also, the special mission of the SBGSU as a law enforcement agency is important. The Administration of the SBGSU is the central executive body with a special status, that implements state policy in the sphere of SBU's protection, and the SBGSU - is a law enforcement agency of specialpurpose (Articles 6, 7 of the Law of Ukraine "On the State Border Guard Service of Ukraine") ${ }^{12}$.

The central executive body with a special status has specific tasks and credentials defined by Ukraine's Constitution and legislation, and a special procedure for the formation, reorganization, liquidation, control, accountability, appointment and dismissal of heads and resolving other issues may be established for it ${ }^{13}$.

The special mission of the SBGSU is determined, first of all, by the sphere's specificity of activity and objects of protection, which is determined by the national interests of the country and its state security: state

${ }^{10}$ Pro rishennia Radi matsionalnoi bezpeki i oboroni Ukrainy [On the decision of the National Security and Defense Council of Ukraine]. May 62015 "Pro strategiyu natsionalnoi bezpeki Ukraini [On the National Security Strategy of Ukraine]": Ukaz Prezidenta Ukraini vid 26.05.2015 No. 287/2015. URL: http://zakon3.rada.gov.ua/laws/show/287/2015 (date of request: 31.10 .2019$)$. [In Ukrainian]

${ }^{11}$ Skakun O.F. Teoria Gosudarstva i prava [State and Law Theory]: Uchebnik. Kharkov: Consum. Un-t. vnutr. del, 2000. P. 139. [In Russian]

${ }^{12}$ Pro Derzhavnu prykordonnu sluzhbu Ukrayiny [On the State Border Guard Service of Ukraine]: zakon Ukrayiny vid 03.04.2003 r. № 661-IV. Data onovlennya: 04.01.2019. URL: http://zakon.rada.gov.ua/laws/main/661-15 (date of request: 31.10.2019.[In Ukrainian]

${ }^{13}$ Administratyvne pravo Ukrayiny [Administrative Law of Ukraine] [Pidruchnyk dlya yuryd. vuziv i fak. / YU.P. Bytyak, V.V. Bohuts'kyy, V.M. Harashchuk ta in.]; Za red. YU.P. Bytyaka. Kharkiv: Pravo, 2001. p. 73. ). [In Ukrainian] 
sovereignty, constitutional order, territorial integrity, etc. Accordingly, the peculiarities of administrative and legal regulation of the managing activities of the Ukrainian state border guard bodies (units) chiefs are determined by SBU's safeguarding field's specifics, namely:

First, the tasks of the executive body responsible for safeguarding of SBU depend entirely on the state's «political regime», domestic and foreign policies. That is, the SBGSU provides political safeguarding of the $\mathrm{SBU}^{14}$, it is an instrument of implementation of Ukraine's border policy in relations with neighboring and other world countries. Ensuring reliable safeguarding of the SBU is one of the stipulations of Ukraine's national security.

Second, the proper performance of SBGSU duties depends on the legal status of SBU with the neighboring state.

Third, the SBGSU is one of the main party of safeguarding and protection of the SBU, that, according to Art. 2 of the Law of Ukraine «On the State Border Guard Service of Ukraine», in addition to other main functions, has the function of coordination military formations' activities and relevant law enforcement agencies related to the protection of the SBU, as well as the activities of state bodies exercising different control types during the crossing of the SBU or involved in procuring of the SBU regime, border regime and the SBU border crossing regime ${ }^{15}$.

Fourth, SBGSU is a professional military organization. Personnel is staffed with military and civilians. Recruitment of SBGSU by military personnel and their military service are carried out based on the Law of Ukraine «On Military Duty and Military Service», the Statutes of the Armed Forces of Ukraine, the Regulations on the military service by the relevant categories of military personnel, etc.

Military organization's (structure) peculiarity is that it is an institution where relationships are built on the principle of unity, statutory rules of relations and are provided with an increased degree of military personnel's responsibility for violating the military service's established order (military crimes) following Art. 401-435 of the Criminal Code of Ukraine, including

${ }^{14}$ Administratyvne pravo Ukrayiny [Administrative Law of Ukraine] [Pidruchnyk dlya yuryd. vuziv i fak. / YU.P. Bytyak, V.V. Bohuts'kyy, V.M. Harashchuk ta in.]; Za red. YU.P. Bytyaka. Kharkiv: Pravo, 2001. p. 471. [In Ukrainian]

${ }^{15}$ Pro Derzhavnu prykordonnu sluzhbu Ukrayiny [On the State Border Guard Service of Ukraine]: zakon Ukrayiny vid 03.04.2003 r. № 661-IV. Data onovlennya: 04.01.2019. URL: http://zakon.rada.gov.ua/laws/main/661-15 (date of request: 31.10.2019).[In Ukrainian] 
for violating the statutory rules for carrying out the border service, under Article 419 of this Code $^{16}$.

Fifth, considering the peculiarities of the official activity of the SBGSU body (unit) chief, it is necessary to take into account particular subdivision's functional assignment's peculiarities, the essence and specificity of its OSA, official task's nature.

The implementation of management depends on the specific position of the body (unit) chief in the SBGSU structure. At present, it is possible to conclude that there are four levels of management system in the SBGSU: higher, regional, middle and lower.

All chiefs of the SBGSU can be contingently divided into body chiefs and unit chiefs. The SBGSU bodies chiefs are the Head of the SBGSU, chiefs of the intelligence body, territorial bodies, Ukrainian state border guard bodies, and others. Such bodies are legal entities, have a seal with the image of the State Emblem of Ukraine and title, other seals and stamps, bank accounts, including in foreign currency. The SBGSU unit chiefs are chiefs of groups, sectors, divisions, subdivisions, departments, departments of the SBGSU bodies, as well as units of the lower level. Such units are usually structural units of bodies.

Management in a service activity is also influenced by whether direct management is exercised alone, or whether the manager has management bodies (deputies) through which he directs the activities of subordinate bodies (units) by delegating his credentials. Some of the SBGSU body chiefs may use collegial and advisory bodies in their management.

Management implementation also depends on the subordinate staff's legal status. The SBGSU personnel (staff) includes military and civilian employees of the SBGSU (hereinafter - employees). Labor relations between the SBGSU and its employees are regulated by the legislation on labor, Ukraine's public service and labor contracts (contracts), with military personnel - following the legislation on military service. This defines the content and features of personnel management in the SBGSU.

Thus, these and other peculiarities influence the content of the SBGSU bodies (units) chiefs managing activities and characterize the features of its administrative and legal regulation. The SBGSU body (unit) chief managing procedure may be regulated by the relevant legal acts or carried out at his discretion. Each chief chooses for themselves the most expedient means, techniques, methods of influencing the subordinates to convince, encourage

\footnotetext{
${ }^{16}$ Kryminal'niy kodeks Ukrayiny [Criminal Code of Ukraine]: Zakon Ukrayiny vid 05 kvitnya 2001 roku № 2341-III. Data onovlennya: 19.10.2019. URL: http://zakon3.rada.gov.ua/ laws/2341-14 (date of request: 31.10.2019).[In Ukrainian]
} 
or compel them to fulfill their assigned tasks, preferring to individual, collegial, collective, combined, administrative, moral, economic or other methods. The SBGSU body chief must know and understand his rights and responsibilities in the management. Otherwise, he is responsible for the failure to perform and negligent performance of his/her duties, including the responsibilities for managing the relevant organizational unit.

\section{The main tendencies of the administrative and legal regulation of the managing activities of the Ukrainian in modern conditions}

Among the main tendencies in the administrative and legal regulation of the SBGSU state border guard bodies (units) chiefs managing activities in the present conditions are the following.

One of the main tendencies of administrative and legal regulation is that further development of the SBGSU is determined at the level of legal acts of the President of Ukraine and the Cabinet of Ministers of Ukraine. As an example, the Concept of Development of the SBGSU for the period up to 2015, which was approved by the Decree of the President of Ukraine of 19.06.2006 No. $546 / 2006$ and the Strategy of the SBGSU, approved by the decree of the Cabinet of Ministers of Ukraine of November 23, 2015, No. 1189.

Thus, according to the Strategy of the SBGSU development, among its main tasks, along with SBU's integrated security management system creation, is the SBGSU management system modernization and improvement of interaction with other bodies that are part of the security and defense sector. The fulfillment of this task is supposed to be carried out due to:

- Management system decentralization;

- expanding SBGSU Main Service Management Center (hereinafter SMC) functional capabilities, improving its activities and organizing interaction with Ukraine Main Situational Center, the Anti-Terrorist Center at the Security Service of Ukraine and departmental situational centers;

- modern information technologies introduced into the system of management and ensuring the protection of information resources;

- providing scientific support for SBGSU development, etc ${ }^{17}$.

Another trend of administrative and legal regulation is the annual determination of the directions of further development of the SBGSU for the calendar year, which is endorsed by the decisions of the SBGSU Board and approved by the Interior Minister.

\footnotetext{
${ }^{17}$ Pro skhvalennya Stratehiyi rozvytku Derzhavnoyi prykordonnoyi sluzhby [On approval of the Strategy for the SBGSU development]: rozporyadzhennya Kabinetu Ministriv Ukrayiny vid 23 lystopada 2015 roku № 1189-r. URL: http://zakon3.rada.gov.ua/laws/show/1189-2015-r (date of request: 31.10 .2019$)$.[In Ukrainian]
} 
So, for example, according to the Main directions of activity and SBGSU further development in 2017, it was supposed:

- to ensure the unification and up-to-date maintenance of information and analytical materials in the SBGSU in the areas of activity at all levels of management;

- to ensure the modern system formation for managing the forces and means of the Maritime Guard of the SBGSU;

- to provide further development of service management automation processes and response to situations, application of innovations in the refinement of SMC as modern control points, increase of their technical capabilities for automated situation monitoring and control over the use of forces and means;

- to ensure the permanent operative staff readiness to perform management tasks at suburban, reserve control points, to bring into compliance with the regulatory documents requirements of the suburban reserve control point operation and a mobile control point of the SBGSU Administration;

- to continue to increase the service management system's effectiveness, to respond promptly to the situation changes in the special period conditions;

- to transform EU and NATO international experience into a personnel management system;

- to improve the staff motivation system, etc ${ }^{18}$.

In accordance with the Main Activities Directions and Further Development of the SBGSU in 2018, it was envisaged to reform the structure management system and number of the SBGSU by optimization of the Border Guard Departments, deployment of Border Inspectorate Departments and Border Control; reforming of the verticals of regional administrations and border squads; bringing the ratio of the organizational structures of SBU safeguarding bodies to the indicator: $75 \%$ - border guard units, $25 \%$ - the management and logistics units; optimization of separate units of the central subordination, etc. ${ }^{19}$

${ }^{18}$ Osnovni napryamy diyal'nosti ta podal'shoho rozvytku Derzhavnoyi prykordonnoyi sluzhby Ukrayiny u 2017 rotsi [Main directions of activity and further development of the SBGS of Ukraine in 2017]: Derzhavna prykordonna sluzhba Ukrayiny, ofitsiynyy sayt. URL: https://dpsu.gov.ua/ua/-osnovni-napryami-diyalnosti-ta-podalshogo-rozvitku-derzhavnoiprikordonnoi-sluzhbi-ukraini/ (date of request: 26.12.2018).[In Ukrainian]

${ }^{19}$ Osnovni napryamy diyal'nosti ta podal'shoho rozvytku Derzhavnoyi prykordonnoyi sluzhby Ukrayiny u 2018 rotsi [Main directions of activity and further development of the SBGS of Ukraine in 2018]: Prykordonnyk Ukrayiny. Hazeta Derzhavnoyi prykordonnoyi sluzhby Ukrayiny, № 3-4 (5593-5594), 26 sichnya 2018 roku. p. 12-15. [In Ukrainian] 
In the Main Activities Directions and Further Development of the SBGSU in 2019, the issues of improvement of management system and structure, the SBGSU chiefs of bodies (units) managing activities are not given enough attention ${ }^{20}$.

Accordingly, among the main tendencies of the administrative and legal regulation of the past years, which negatively affected the quality of the tasks assigned to the SBGSU on safeguarding of the SBU, was its focus on ensuring the managing activities of the heads of the highest management bodies of the SBGSU, which negatively affected the situation of ensuring border guard activities of the SBGSU bodies (units). As a result, certain disparities in the correlation between the lead units of the SBGSU and the number of personnel involved in the border guard activities were observed.

Regarding the total number of personnel of the SBGSU, as of August 1, 1991, the number of Border troops of Ukraine was 16800 military and civilian employees. Subsequently, this figure increased and as of December 30, 2004, was to be 50,000 (of which 47,000 were military). After the creation of the SBGSU, the Law of Ukraine «On the State Border Guard Service of Ukraine» of April 3, 2003 (came into force on August 1, 2003), taking into account personnel existing number, it was also envisaged to increase it gradually by 5000 every year during 2004-2005 and bringing it to 50,000 as of January 1, 2005 (42,000 of the military). Under the Law of Ukraine «On Amendments to Article 6 of the Law of Ukraine» On the State Border Guard Service of Ukraine «of April 9, 2015, No. 306-VIII, the SBGSU of Ukraine increased by 3000 and the number of its personnel was determined in 53000 persons (45000 of the military personnel).

Considering the length of the SBU, which is $6992,982 \mathrm{~km}$ (of which land $-5637,982 \mathrm{~km}$, the maritime border $-1355,0 \mathrm{~km}$, the exclusive (maritime) economic zone - 72658 square kilometers. With the CIS states $4601,24 \mathrm{~km}$, with the EU member states $-1390,742 \mathrm{~km}$. The territorial sea - $1001 \mathrm{~km})^{21}$, then for $1 \mathrm{~km}$ of SBU out of 45,000 there were more than 6 military employees (provided that all of them are involved in the safeguarding of the SBU). But practice shows that this figure was much lower.

Back in 2016, Secretary of the Interior of Ukraine Arsen Avakov declared the idea of reducing the number of generals in the structures, which

\footnotetext{
${ }^{20}$ Osnovni napryamy diyal'nosti ta podal'shoho rozvytku DPS Ukrayiny u 2019 rotsi [Main directions of activity and further development of the SBGSU in 2019]. https://dpsu.gov.ua/upload/Naprjami_DPSU_Optimized (date of request: 31.10.2019).[In Ukrainian]

${ }^{21}$ Osnovni napryamy diyal'nosti ta podal'shoho rozvytku DPS Ukrayiny u 2019 rotsi [Main directions of activity and further development of the SBGSU in 2019]. https://dpsu.gov.ua/upload/Naprjami_DPSU_Optimized (date of request: 31.10.2019).[In Ukrainian]
} 
are subordinate to his agency. The Facebook page stated that on behalf of the President of Ukraine he submitted for approval a draft of the reduction of general's positions. It was proposed that the staff of general's positions and ranks in the SBGSU (with some about 42 thousand people) should be reduced from 74 to $14^{22}$. However, for the period from 2016 to 2019 , only 20 such positions were cut in the SBGSU. Information about the number of general's positions was in the interview with the Head of the SBGSU. "There were 54 general's positions in the SBGSU. At the time of my appointment to the post, 38 people held the rank of General. After the administrative reform, we cut 6 general positions. And at the end of the reform, we have only 19 generals left," S. Deineko said ${ }^{23}$.

For this purpose, a set of measures is being implemented to optimize the management levels and units of the structure of the SBGSU and eliminate unnecessary ones. So, today, the SBGSU Administration structure has been reformed, and 4 of 8 regional branches of the SBGSU have been liquidated. According to the Head of the SBGSU S. Deyneko: "Service reform is necessary from the top down. If once there were 3 regional offices until 2001, now the structure contains 8 offices. We want to save 4 regional offices in the Service, and then completely abandon them. We want to bring the SBGSU to European analogs». He cited the example of Poland, where a three-level system of management exists - the units that directly guard the border, then the border unit and the Warsaw-based administration. There is a similar structure in the US; they do not have any regional leaders ${ }^{24}$.

The main tendencies of administrative and legal regulation of managing activities should also include repeated changes in the issues of appointment of the senior leadership of the SBGSU and the distribution of relevant credentials among the higher officials of the state.

The Head of the State Committee for Ukrainian state border guard Commander of the Border Guard of Ukraine, at some time was appointed and dismissed by the President of Ukraine. It was also determined concerning the Head of the SBGSU, the appointment and dismissal of which was made by the President of Ukraine. Then the appointment of the

\footnotetext{
${ }^{22}$ Povidomlennya na ofitsiyniy storintsi facebook Ministra vnutrishnikh sprav Ukrayiny Arsena Avakova [The announcement on the official facebook page of the Secretary of the Interior of Ukraine Arsen Avakov]. URL: https://www.facebook.com/arsen.avakov.1/posts/ 1108372932586145?pnref=story (date of request: 27.10.2019) [In Ukrainian]

${ }^{23}$ Interv'yu Holovy DPS Ukrayiny [Interview with the Chairman of the SBGSU]. URL: https://www.ukrinform.ua/rubric-ato/2796747-kilkist-generaliv-u-derzprikordonsluzbi-skorotatudvici-dejneko.html (date of request: 27.10.2019) [In Ukrainian]

${ }^{24}$ Interv'yu Holovy DPS Ukrayiny [Interview with the Chairman of the SBGSU]. URL: https://www.blackseanews.net/read/156590 (date of request: 27.10.2019) [In Ukrainian]
} 
President of Ukraine was envisaged on the submission of the Prime Minister of Ukraine.

Under paragraph 10 of the current Regulation on the Administration of the SBGSU, the Head of the SBGSU is appointed to the post and dismissed by the Cabinet of Ministers of Ukraine upon the submission of the Prime Minister of Ukraine, submitted based on proposals of the Secretary of the Interior. The SBGSU Head has two deputies, including the first deputy, who are appointed and dismissed by the Cabinet of Ministers of Ukraine on the proposal of the Prime Minister of Ukraine, submitted based on proposals of the Secretary of the Interior ${ }^{25}$.

The content norms of this Regulation are in contradiction with the requirements of Article 8 of the Law of Ukraine "On the State Border Guard Service of Ukraine", second part of which states that the Head of the SBGSU is appointed by the President of Ukraine upon the submission of the Prime Minister of Ukraine and suspends his credentials on this position. The Head of the SBGSU has deputies who are appointed by the President of Ukraine upon SBGSU Head's submission ${ }^{26}$.

The Decree of the President of Ukraine dated October 25, 2019 №774 / 2019 lists the positions of military formations heads, law enforcement agencies, candidates for appointment to which agrees with the President of Ukraine on the SBGSU: SBGSU Administration departments' directors; SBGSU regional departments chiefs; rector of the National Academy of SBGSU named after B. Khmelnitsky ${ }^{27}$. To avoid different approaches to these issues, there is a need for such coordination, etc.

According to the results of past studies, the structural level of the SBGSU, which officials use the most managing methods, according to the respondents, are Ukrainian state border guard bodies and the Maritime Guard Bodies (77.7\%), and the effectiveness of service activities management depends on border guard bodies chiefs $(66.6 \%)$ and border guard units chiefs $(51.1 \%)$ and the SBGSU Maritime Guard Bodies. The

\footnotetext{
${ }^{25}$ Pro zatverdzhennya Polozhennya pro Administratsiyu Derzhavnoyi prykordonnoyi sluzhby Ukrayiny [On Approval of the Regulation on the Administration of the State Border Guard Service of Ukraine]: Postanova Kabinetu Ministriv Ukrayiny vid 16 zhovtnya 2014 r. № 533. Data onovlennya: 07.08.2015. URL: http://zakon2.rada.gov.ua/laws/show/533-2014-p (date of request: 31.10.2019) [In Ukrainian]

${ }^{26}$ Pro Derzhavnu prykordonnu sluzhbu Ukrayiny [On the State Border Guard Service of Ukraine]: zakon Ukrayiny vid 03.04.2003 r. № 661-IV. Data onovlennya: 04.01.2019. URL: http://zakon.rada.gov.ua/laws/main/661-15 (date of request: 31.10.2019).[In Ukrainian]

${ }^{27}$ Pro vnesennia zmin do Ukazu Prezidenta vid 4 chervnia 2008 roku №516 [On Amendments to the Presidential Decree of June 4, 2008 No. 516]: Ukaz Prezidenta Ukrainy vid 25 zhovtnia 2019 №774/2019 URL: https://www.president.gov.ua/documents/7742019-30077 ((date of request: 27.10.2019) [In Ukrainian]
} 
main reason, which hinders the organization of effective management of the official activities the SBGSU bodies (units), is the imperfection of the legislation on the SBU $(57.8 \%)^{28}$.

The elimination of the relevant shortcomings and contradictions should be a priority in the administrative and legal regulation of managing activities.

There are many other problematic issues that are caused by the state of administrative and legal regulation of the Ukrainian border guard bodies (units) activities in the current conditions: lower-level bodies' (units) incompleteness, staff turnover, lack of a clear promotion program, low level of border guard bodies (units) motivation, etc. All of them need to be resolved, including by amending Ukraine's current legislation, improving management.

\section{CONCLUSION}

Thus, the administrative and legal regulation of the managing activities of the SBGSU bodies (units) chiefs is of great importance and consists of a set of legal acts that proclaim legal norms, regulate managing activities, and determine the content of public relations between subjects and objects of management. Such regulation is carried out at the level of Ukraine's laws and by-laws, which can be divided into the following groups: the Constitution and the laws of Ukraine; resolutions of the Verkhovna Rada of Ukraine; Decrees and Orders of the President of Ukraine; resolutions and orders of the Cabinet of Ministers of Ukraine; orders of the Ministry of Interior and the SBGSU Administration, orders of the SBGSU managing bodies.

In such hierarchical structures as the SBGSU, built on the principle of unity, administrative and legal regulation of chiefs' managing activities is of particular importance. The chief is an official - a staff member appointed to a certain position, determined by the structure and staff list of the SBGSU body, entrusted with a set of official credentials for the implementation of organizational, advisory or administrative functions, as well as certain credentials concerning subordinates to make management decisions and their implementation.

At present, the specification of the essence and the establishment of clear procedural rules of management are mainly carried out not at Ukraine's laws

\footnotetext{
${ }^{28}$ Polovnikov V.V. Problemni pitannia ta shliahi udoskonalennia kerivnikami organiv (pidrozdiliv) DPS Ukrainy metodiv upravlinnia [Problematic Issues and Ways to Improve Management Methods of Heads of Bodies (Units) of the SBGS of Ukraine]: Visnik NADPSU. Seria: Uridichni nauki 2018. Vip.4 URL: http://nbuv.gov.ua/UJRN/vnadpcurn_2018_4_6
} 
level but by-laws level. This does not fully comply with the principle of legal certainty.

\section{SUMMARY}

One of the important components of Ukraine legal system reform is the improvement of administrative and legal regulation of the SBGU state border guard bodies (units) chiefs' managing activities. Only that system of management is effective, which is constantly evolving and refined based on the use of accumulated experience, improvement of its legal regulation. Some peculiarities and problematic issues of management activities are characteristic not only for the SBGSU but also for other Ukrainian law enforcement agencies and military formations.

Improvement of administrative and legal regulation of managing activities and implementation in practice of the legal certainty principle is possible in case of clear definition and specification of the managing activities procedures, not at the by-laws level, but at the level of Ukraine's laws.

The SBGSU body chief must know and understand his rights and responsibilities in the management. It concerns his tasks, duties and rights to manage the relevant organizational and structural unit. Otherwise, he may be a subject to disciplinary, administrative, criminal and other legal liability for failure to perform or negligent performances of his duties.

The enlightened provisions provide the basis for further research into these issues, the development of theoretical and practical foundations for the management implementation, improvement of Ukraine's current legislation.

\section{REFERENCES}

1. Konstitutsia Ukrayini: zakon Ukrayini № 254к/96-VR [Constitution of Ukraine]. 28 June 1996. Data onovlennia: 21.02.2019. URL: http://zakon2.rada.gov.ua/laws/main/254к/96-вp (date of request: 31.10.2019). [In Ukrainian]

2. Rishenniya Konstitutsiynogo sudu Ukrainy №. 17-rp / 2010 [Judgment of the Constitutional Court of Ukraine]. 29 June 2010. URL: https://zakon.rada.gov.ua/laws/show/v017p710-10 (date of request: 31.10.2019). [In Ukrainian]

3. Yuridichna Ensiklopediya [Legal Encyclopedia] / red. Y.S.Shemshuchenko [ta insh.] / NAN Ukrainy, V.M. Koretsky Institut derzavi i prava. Kyiv: vid. Ukrainska entsiklopediya im. M.P. Bazhana, Toml. 3: K-M. 2001. P. 617. [In Ukrainian] 
4. Babosov, E. M. Sotsyolohyya upravleniya : posobye dlya studentov vuzov [Sociology of management] / E. M. Babosov. 6-e izd., pererab. y dop. Mynsk : TetraSystems, 2010. S. 3-4.[In Ukrainian]

5. Velykyy tlumachniy slovnyk suchasnoyi ukrayins'koyi movy [The Big Interpretive Dictionary of Modern Ukrainian] / Uklad. i holov. red. V. T. Busel. Kyiv; Irpin': VTF «Perun», 2009. S. 1511. [In Ukrainian]

6. Noviy tlumachniy slovnyk ukrayins'koyi movy : u 3 t. 200000 sliv [New interpretative dictionary of the Ukrainian language] / [uklad. Vasyl' Yaremenko, Oksana Slipushko]. vyd. 2-e, vypr., t. 3 P-YA. Kyiv : AKONIT, 2008. S. 624-625. [In Ukrainian]

7. Yuridichna Ensiklopediya [Legal Encyclopedia] / red. Y.S.Shemshuchenko [ta insh.] / NAN Ukrainy, V.M. Koretsky Institut derzavi i prava. Kyiv: vid. Ukrainska enciklopedia im.r M.P. Bazhan, Tom.T. 6: T-Y. 2004, p. 768. [In Ukrainian]

8. Pro rishennia Radi matsionalnoi bezpeki i oboroni Ukrainy [On the decision of the National Security and Defense Council of Ukraine]. 6 May 2015 "Pro strategiyu natsionalnoi bezpeki Ukraini [On the National Security Strategy of Ukraine]": Ukaz Prezidenta Ukraini vid 26.05.2015 No. 287/2015. URL: http://zakon3.rada.gov.ua/laws/show/287/2015 (date of request: 31.10.2019). [In Ukrainian]

9. Skakun O.F. Teoria Gosudarstva i prava [State and Law Theory]: Uchebnik. Kharkov: Consum. Un-t. vnutr. del, 2000. p. 704 [In Russian]

10. Pro Derzhavnu prykordonnu sluzhbu Ukrayiny [On the State Border Guard Service of Ukraine]: zakon Ukrayiny vid 03.04.2003 r. № 661-IV. Data onovlennya: 04.01.2019. URL: http://zakon.rada.gov.ua/laws/ main/661-15 (date of request: 31.10.2019. [In Ukrainian]

11. Administratyvne pravo Ukrayiny [Administrative Law of Ukraine] [Pidruchnyk dlya yuryd. vuziv i fak. / YU.P. Bytyak, V.V. Bohuts'kyy, V.M. Harashchuk ta in.]; Za red. YU.P. Bytyaka. Kharkiv: Pravo, 2001. p. 73.). [In Ukrainian]

12. Kryminal'niy kodeks Ukrayiny [Criminal Code of Ukraine]: Zakon Ukrayiny vid 05 kvitnya 2001 roku № 2341-III. Data onovlennya: 19.10.2019. URL: http://zakon3.rada.gov.ua/laws/2341-14 (date of request: 31.10.2019).[In Ukrainian]

13. Pro skhvalennya Stratehiyi rozvytku Derzhavnoyi prykordonnoyi sluzhby [On approval of the Strategy for the SBGSU development]: rozporyadzhennya Kabinetu Ministriv Ukrayiny vid 23 lystopada 2015 roku № 1189-r. URL: http://zakon3.rada.gov.ua/laws/show/1189-2015-r (date of request: 31.10 .2019$)$.[In Ukrainian] 
14. Osnovni napryamy diyal'nosti ta podal'shoho rozvytku Derzhavnoyi prykordonnoyi sluzhby Ukrayiny u 2017 rotsi [Main directions of activity and further development of the SBGSU in 2017]: Derzhavna prykordonna sluzhba Ukrayiny, ofitsiynyy sayt. URL: https://dpsu.gov.ua/ua/-osnovni-napryami-diyalnosti-ta-podalshogo-

rozvitku-derzhavnoi-prikordonnoi-sluzhbi-ukraini/ (date of request: 26.12.2018).[In Ukrainian]

15. Osnovni napryamy diyal'nosti ta podal'shoho rozvytku Derzhavnoyi prykordonnoyi sluzhby Ukrayiny u 2018 rotsi [Main directions of activity and further development of the SBGSU in 2018]: Prykordonnyk Ukrayiny. Hazeta Derzhavnoyi prykordonnoyi sluzhby Ukrayiny, № 3-4 (5593-5594), 26 January 2018 p. 12-15. [In Ukrainian]

16. Osnovni napryamy diyal'nosti ta podal'shoho rozvytku DPS Ukrayiny u 2019 rotsi [Main directions of activity and further development of the SBGSU in 2019]. https://dpsu.gov.ua/upload/Naprjami_DPSU_ Optimized (date of request: 31.10.2019).[In Ukrainian]

17. Povidomlennya na ofitsiyniy storintsi facebook Ministra vnutrishnikh sprav Ukrayiny Arsena Avakova [The announcement on the official facebook page of the Secretary of the Interior of Ukraine Arsen Avakov]. URL: https://www.facebook.com/arsen.avakov.1/posts/ 1108372932586145?pnref=story (date of request: 27.10.2019) [In Ukrainian]

18. Interv'yu Holovy DPS Ukrayiny [Interview with the Chairman of the SBGSU]. URL: https://www.ukrinform.ua/rubric-ato/2796747-kilkistgeneraliv-u-derzprikordonsluzbi-skorotat-udvici-dejneko.html (date of request: 27.10.2019) [In Ukrainian]

19. Interv'yu Holovy DPS Ukrayiny [Interview with the Chairman of the SBGSU]. URL: https://www.blackseanews.net/read/156590 (date of request: 27.10.2019) [In Ukrainian]

20. Pro zatverdzhennya Polozhennya pro Administratsiyu Derzhavnoyi prykordonnoyi sluzhby Ukrayiny [On Approval of the Regulation on the Administration of the State Border Guard Service of Ukraine]: Postanova Kabinetu Ministriv Ukrayiny vid 16 zhovtnya 2014 r. № 533. Data onovlennya: 07.08.2015. URL: http://zakon2.rada.gov.ua/ laws/show/533-2014-p (date of request: 31.10.2019) [In Ukrainian]

21. Pro vnesennia zmin do Ukazu Prezidenta vid 4 chervnia 2008 roku №516 [On Amendments to the Presidential Decree of June 4, 2008 No. 516]: Ukaz Prezidenta Ukrainy vid 25 zovtnia 2019 №774/2019 URL: https://www.president.gov.ua/documents/7742019-30077 (date of request: 27.10.2019) [In Ukrainian] 
22. Polovnikov V.V. Problemni pitannia ta shliahi udoskonalennia kerivnikami organiv (pidrozdiliv) DPS Ukrainy metodiv upravlinnia [Problematic Issues and Ways to Improve Management Methods of the SBGSU Heads of Bodies (Units)]: Visnik NADPSU. Seria: Uridichni nauki 2018. Vip.4 URL: http://nbuv.gov.ua/UJRN/vnadpcurn_2018_4_6.

\section{Information about the author:} Vadym Polovnikov,

Candidate of Juridical Sciences, Associate Professor, Department of Operative and Investigative Activity Management National Academy of State Border Guard Service of Ukraine named after Bohdan Khmelnytskyi Khmelnytskyi city, st. Shevchenko 46 ORCID ID: orcid.org/0000-0002-8054-909X 
DOI https://doi.org/10.36059/978-966-397-159-9/89-108

\section{TOPICAL DIRECTIONS FOR IMPROVEMENT OF INFORMATION RELATIONS IN ACTIVITIES OF THE STATE BORDER GUARD SERVICE OF UKRAINE}

\section{Iryna Kushnir}

\section{INTRODUCTION}

Ukraine's aspiration to join the European Union needs to adapt national legislation to the legislation of the European Union and requires the state authorities to take decisive steps to achieve a new, qualitative and appropriate level of development. One of these directions for development is the system of state border protection, which needs to bring the principles, forms and methods of state border protection, border control procedures in line with generally accepted norms of the European Union. The issues related to the development of the state border protection system are quite important and urgent due to not only the external (international) factors but to the internal ones as well. In the modern context, the legal status of the State Border Guard Service of Ukraine (SBGS) and the departmental priorities (improving the effectiveness of state policy implementation in the field of state border security ${ }^{1}$ ) are at a stage of development, which is caused by the change of threats at the state border and require decisive legal steps and the most optimal ones are introduced in European countries ${ }^{2}$.

The constant change in the nature of threats at the state border of Ukraine requires adequate response, as the consequence of the activities of the SBGS is the appropriate national security level (security of the nation, society and individual citizen) in terms of inviolability of the state border of Ukraine, preventing the change of the border line and realization of the right of unimpeded crossing of the state border of Ukraine ${ }^{3}$. Border security as a

\footnotetext{
${ }^{1}$ Main Directions of Activities and Further Development of SBGS of Ukraine in 2019. URL: dpsu.gov.ua/upload/Haprjami_ДПСУ_Optimized.pdf. (accessed 11 October 2019).

${ }^{2}$ Kaliuzhnyi R. A., Kushnir I. P. (2015) Pravove zabezpechennja vzajemodiji publichnoji administraciji u prykordonnij sferi [Legal Support for Public Administration Interaction in the Sphere of Border Guarding]. Kyiv: "MP Lesia”. p. 159. (in Ukrainian).

${ }^{3}$ Liashuk R. M., Kushnir I. P. (2017) Rezuljtatyvnistj ta efektyvnistj $v$ dijaljnosti orghaniv okhorony derzhavnogho kordonu Ukrajiny [Effectiveness and Efficiency in Activities of the State Border Protection Bodies of Ukraine]. Law and Society, No. 5, p. 158. (in Ukrainian).
} 
component of national security is provided by a set of various measures and provides for the protection of the interests of the individual, society and state in this field ${ }^{4}$. An element of modern border security is its information component with information relations being one of its dimensions.

The intensive development of the information society, the total informatization of the public and private sphere, the introduction of electronic means for identification of personality, taking into account the European integration, require the SBGS to continuously improve its information activities. With this in mind, it is worth mentioning the consideration of Yu. Ye. Maksymenko, who states that the information branch of legislation is the most dynamic in relation to other branches of legislation, and the intensity of changes in the information sphere contributes to the need for special attention of the scientific community to the study of the current information legislation, the state of information relations in Ukraine $^{5}$.

Information relations, which are conditioned both by the internal organizational aspects of the information activities of the SBGS and the provision of information rights of citizens (within the competence), require timely coverage and regulation by legal acts, the creation and improvement of clear organizational mechanisms for information support and the adequate state of information security. The issue of improving information relations in the field of SBGS activities is closely related to the expected result, final impact and their impact on the state of border security.

The need for continuous development of border security, the introduction of European standards for integrated border management, improvement of confidence in the SBGS, intensive development of information society (emergence of new formats of information communication), as well as the necessity of confronting hybrid (information) war, determine the relevance of information relations development in the SBGS activities.

\section{Substantiation of necessity to develop norms of information legislation}

Actual fundamentals for improving information relations in the SBGS activities are formulated in the regulatory requirements of information society development at the state and departmental levels, substantiated in

\footnotetext{
${ }^{4}$ Kushnir I. P. (2018) Analiz zmistu ponjattja «bezpeka derzhavnogho kordonu» [Content Analysis of "State Border Security" Concept]. Bulletin of the Southern Regional Centre of the National Academy of Law Sciences of Ukraine,. No. 16, p. 78. (in Ukrainian).

5 Maksymenko Yu. Ye. (2014) Normatyvno-pravove reghuljuvannja informacijnykh vidnosyn v Ukrajini: stan ta perspektyvy [Legal Regulation of Information Relations in Ukraine: Status and Prospects]. Legal Bulletin, No. 3, p. 142. (in Ukrainian).
} 
programmes, plans, strategies, concepts oriented on the development of the national and state security system, observance of citizens' rights, compliance with the requirements of Ukrainian and international information society.

Increasing the role of information, developing the forms of its display and application (electronic communication, improving the use of information and telecommunication systems, the use of electronic qualified signatures, electronic identification) in the activities of the SBGS enable to emphasize the relevance and the need for quality regulatory and legal support of informational relations in the sphere of border guarding. It should be built on a systematic basis that will help to achieve the desired goal - a stable state of security of Ukraine's state borders.

The main coordinates for the development of information relations are laid down in the planning documents designed for a certain period, taking into account the European guidelines. Thus, the Plan of Measures to Implement the National Strategic Course for Acquiring Full Membership of Ukraine in the European Union and in the North Atlantic Treaty Organization, approved by Presidential Decree No 155/2019 of April 20, 2019, provides for the implementation of effective information policy in the fields of European and North Atlantic integration of Ukraine and expand of cooperation with the EU on information security and cyber-security, ensuring the resistance of critical infrastructure, countering transnational crime, enhancing border security, and minimizing the risks in the sphere of migration ${ }^{6}$.

In the direction of ensuring information security of the state in the current context, the Doctrine of Information Security formulates the priorities of the state policy in the information sphere, in particular, the relevant ones for the sphere of border guarding are: creation of an integrated system for information threats assessment and prompt response to them ${ }^{7}$. Development of the risk analysis system in the SBGS of Ukraine started in $2006^{8}$, and improvements are still underway today; improvement of the SBGS authority in order to achieve an adequate level of capabilities to

${ }^{6}$ Plan of Measures for Realization of the Strategic Course of the State to Acquire Full Membership of Ukraine in the European Union and in the North Atlantic Treaty Organization: by Presidential Decree No. 155/2019 of April 20, 2019. art. 15, 17. URL: https://www.president.gov.ua/documents/1552019-26586. (accessed 18 October 2019).

${ }^{7}$ On the decision of the National Security and Defence Council of Ukraine of December 29, 2016 "On the Doctrine of Information Security of Ukraine": Presidential Decree of February 25, 2017 No. 47/2017. art. 5. Official Bulletin of the President of Ukraine. 2017. No. 5. Art. 102.

${ }^{8}$ Development of the system of risk analysis in the State Border Guard Service of September 19, 2017. URL : http://dpsu.gov.ua/ua/rozvitok-sistemi-analizu-rizikivderzhprikordonsluzhbi-/. (accessed 4 October 2019). 
respond to real and potential threats to Ukraine's national interests in the border information sphere; legislative regulation of the mechanism for revealing, fixing, blocking and removing information that promotes war or violation of the territorial integrity of Ukraine, threatens state sovereignty from the information space of the state; development and protection of technological infrastructure to provide border information security of Ukraine; provision of full coverage of the territory of Ukraine with digital broadcasting, especially in the border areas, as well as temporarily occupied territories; intensification of counteraction to special information operations aimed at violating sovereignty and territorial integrity, undermining Ukraine's defence capability, demoralizing the SBGS personnel, escalating social and political situation, in particular, in border areas; prevention of free circulation of information products (printed and electronic), primarily originating from the territory of the aggressor state, containing propaganda of war, national and religious enmity, changing the constitutional order by force or violating Ukraine's sovereignty and territorial integrity, provoking mass disturbances. Control over importation of such printed products in Ukraine is carried at border crossing points ${ }^{9}$ or entry exit check points while entering the temporarily occupied territory and leaving it by relevant SBGS units $^{10}$; conduct of actions by intelligence agencies of Ukraine in order to promote and protect national interests of Ukraine in the information sphere, to counteract external threats to the information security of the state outside Ukraine ${ }^{11}$. The SBGS carries out operational and investigation activities independently, serving the interests of state border security, and in the process of conducting intelligence activities it should contribute to the realization and protection of national interests of Ukraine in the information sphere, counteract the external threats to the information security of the state $^{12}$.

9 "On Border Control": Law of Ukraine of November 5, 2009. Bulletin of the Verkhovna Rada of Ukraine. 2010. No. 6. Art. 46.

${ }^{10}$ On Approval of the Procedure for Entering and Leaving Temporarily Occupied Territory of Ukraine (as amended): Resolution of the Cabinet of Ministers of Ukraine of June 4, 2015. No. 367. URL: http://zakon5.rada.gov.ua/laws/show/367-2015-\%D0\%BF. (accessed 20 October 2019).

${ }^{11}$ On the decision of the National Security and Defence Council of Ukraine of December 29, 2016 "On the Doctrine of Information Security of Ukraine": Presidential Decree of February 25, 2017 No. 47/2017. art. 5. Official Bulletin of the President of Ukraine. 2017. No. 5. Art. 102.

${ }^{12}$ On the decision of the National Security and Defence Council of Ukraine of December 29, 2016 "On the Doctrine of Information Security of Ukraine": Presidential Decree of February 25, 2017 No. 47/2017. art. 6. Official Bulletin of the President of Ukraine. 2017. No. 5. Art. 102. 
Creation of conditions for the safe functioning of cyberspace; its use for the benefit of individual, society and the state is provided for by the Strategy of Cybersecurity of Ukraine ${ }^{13}$.

The lack of systematic planning for the development of information society and information security is a significant drawback at the present stage of information relations development. Back in 2014, the Verkhovna Rada of Ukraine adopted a resolution "On Recommendations of Parliamentary Hearings on: "Legislative Support for the Development of Information Society in Ukraine"" in which the Cabinet of Ministers of Ukraine obliged to develop a program for the development of the information society in Ukraine for 20162020. In this regard, the Department of Information Policy developed a draft Strategy for the Development of Information Space of Ukraine for the Period up to 2020; its main purpose was to create the political, economic, organizational and logistical conditions for the development of the national information space of Ukraine, and also to develop a modern model of state information policy, to ensuring the development and protection of the national information space ${ }^{14}$. But that draft has not been signed and appropriately implemented in public relations, so at the state level there is a fragmentary settlement of certain issues of information relations in the aspect of information security, cyber security, etc.

Within the specific activities of the SBGS and ensuring the protection of the state border of Ukraine, there are also decisive normative acts, which direct the development of the border guard agency, taking into account the existing threats and needs of the sphere of border guarding, as well as formulate specific tasks for particular directions of information relations. These include the decrees of the Cabinet of Ministers of Ukraine, the Strategy for Development of the State Border Guard Service of Ukraine (hereinafter referred to as the Strategy), the Strategy for Integrated Border Management for the Period up to 2025, Decisions of the SBGS Board (specifying specific tasks for the development of information component for a certain period). The provisions of these documents define and specify the directions of information and legal activities of the SBGS within the limits defined by the legislation, taking into account threats in the field of state border protection, integration processes and improvement of its information

\footnotetext{
${ }^{13}$ Cyber Security Strategy of Ukraine: Presidential Decree No. 96/2016 of March 15, 2016. Uriadovyi Kurier. 2016. No. 52.

${ }^{14}$ Draft Decree of the President of Ukraine on Approval of the Strategy for the Development of Information Space of Ukraine for the Period up to 2020. URL : http://comin.kmu.gov.ua/control/uk/publish/article?art_id=113102\&cat_id=61025. (accessed 12 October 2019).
} 
component. Such provisions can be called program documents in the field of information relations of the $\mathrm{SBGS}^{15}$.

The Strategy declares that in the direction of the information component development of the state border protection system, it is planned to improve the system of analysis and evaluation of information, as well as to upgrade the system of communication, informatization and protection of information through: bringing mechanisms for the accumulation, processing, evaluation and analysis of information in line with European standards; improving the system of risk analysis, introducing modern technologies for carrying out a consistent multidimensional assessment of the situation at the state border, forecasting its development at all levels of management; developing existing mechanisms for the exchange of open statistical and analytical information between subjects of integrated border management and border guard authorities of the Member States of the European Union, as well as international organizations and institutions; modernizing the system for processing information about persons crossing the state border, their travel documents using electronic media, including the biometric control function; improving the components of the integrated information and telecommunication system "Hart" and upgrading the integrated interagency information and telecommunication system "Arkan" regarding the control of persons, vehicles and goods crossing the state border; deploying mobile automated workstations with access to databases, a modern video surveillance system, a special telecommunication system in the state border guard bodies; introducing an electronic document circulation system using electronic digital signature, modern complexes for cryptographic protection of information, the latest means for special communication on mobile objects, and mechanisms for cyber-security in information and telecommunication systems ${ }^{16}$.

Taking this into consideration, it should be noted that the interdepartmental provision of information relations in the SBGS is based on the basic requirements of legislative acts, involves the introduction and use of modern tools and methods for processing, transmission, analysis, storage of information, comprehensive information exchange, which are focused on improvement of information-oriented provision of inter-agency activities of

${ }^{15}$ Kushnir I. P. (2018) Informacijno-pravova dijaljnistj Derzhavnoji prykordonnoji sluzhby Ukrajiny: normatyvno-pravovyj aspekt [Information and Legal Activities of the State Border Guard Service of Ukraine: Regulatory Aspect]. Constitutional and Legal Academic Studies, No. 2, p. 168. (in Ukrainian).

${ }^{16}$ On Approval of the State Border Guard Service Development Strategy: Decree of the Cabinet of Ministers of Ukraine of November 23, 2015. No. 1189-r. Uriadovyi Kurier. 2015. No. 220 
the SBGS as a manager of information in the field of state border protection. But such measures are predominantly technical and organizational in nature and are mostly in the process of formation and development. In addition, at the national level, there are a number of negative aspects, which are caused by the lack of systematic regulation of information relations, which in a certain way affects the state of information relations in the SBGS activities, and require improvement accordingly.

The main cornerstone of normative legal regulation of information relations in the SBGS activities is the disorder of information legislation norms. This position is monitored in almost all scientific studies on the problems of information law, information relations, certain aspects of the subject-object composition of these relations. The necessity to improve information law is driven by real needs, namely: recent adoption of a large body of information legislation that is sometimes inconsistent or even controversial; rapid development of the information society, information technologies which mechanisms do not keep up with the conditions of time; stay of information law (as a complex, cross-sectoral branch of law, as a science) at the stage of formation and development.

V. O. Shepeta points out that the Ukrainian information legislation is difficult to recognize as effective, despite a rather large number of regulatory documents regulating information relations in the information sphere ${ }^{17}$.

The basic requirement of the information and legal doctrine is to systematise legislation on information issues. In the science of information law, such requirements are substantiated by the following reasons: unnecessary duplication; identification and elimination of gaps in legislation; reduction of timeframe for creating acts; improvement of their quality and efficiency of the norms included in them ${ }^{18}$; there are numerous normative and legal acts for regulation of information legal relations of different legal force; dynamic character of information relations; non-conformity with European Union standards; the declarative nature of individual norms due to the lack of a mechanism for right implementation; the need for a systematic solution to the problem of legal regulation of public relations in the field of

17 Shepeta V. O. (2012) Administratyvno-pravovi zasady tekhnichnogho zakhystu informaciji [Administrative and Legal Principles of Technical Protection of Information]. Kyiv: FOP O. P. Lipkan. p. 183. (in Ukrainian).

${ }^{18}$ Aristova I. V. (2000) Derzhavna informacijna polityka: orghanizacijno-pravovi aspekty [State Information Policy: Organizational and Legal Aspects]. Kharkiv: University of Internal Affairs. p. 174-179. (in Ukrainian). 
information security ${ }^{19}$; there are conflicts and competition of legal acts regulating legal relations in the information sphere; fragmentation and situational nature of right regulation; inconsistency of the conceptual and categorical apparatus (information terminology), which is fixed in normative and legal acts; multitude and ramified structure of legal acts, which complicates their enforcement and control over implementation; domination of by-laws over laws ${ }^{20}$; declarativity of information legislation norms without a mechanism and procedure for their implementation, which causes a significant number of offences; a number of banquet norms, abstract, subjective, technical concepts that need further official clarification or a clear attachment of definitions; lack of attachment for basic concepts ${ }^{21}$; there are conflicts and competition of legal acts regulating legal relations in the information sphere; fragmentation and situational nature of right regulation; inconsistency of the conceptual and categorical apparatus (information terminology), which is fixed in normative and legal acts; multitude and ramified structure of legal acts, which complicates their enforcement and control over implementation; inconsistency of some norms of information legislation adopted at different times; domination of by-laws over laws ${ }^{22}$; information law is lagging behind practice ${ }^{23}$.

This list of reasons should include the availability of departmental legal acts on regulation of information activities of the SBGS which are restricted for the general access, the state registration mechanism is not implemented in respect of certain acts, etc. These reasons prove the need to improve the legislation regulating information relations with sufficient substantiation and meets the basic principles of the theory of law and legislative process.

${ }^{19}$ Maksymenko Yu. Ye. (2007) Teoretyko-pravovi zasady zabezpechennja informacijnoji bezpeky Ukrajiny [Theoretical and Legal Principles for Ensuring Information Security of Ukraine]. Kyiv. p.146 .(in Ukrainian).

20 Shepeta V. O. (2012) Administratyvno-pravovi zasady tekhnichnogho zakhystu informaciji [Administrative and Legal Principles of Technical Protection of Information]. Kyiv: FOP O. P. Lipkan. p. 183. (in Ukrainian).

${ }^{21}$ Maksymenko Yu. Ye. (2014) Normatyvno-pravove reghuljuvannja informacijnykh vidnosyn v Ukrajini: stan ta perspektyvy [Legal Regulation of Information Relations in Ukraine: Status and Prospects]. Legal Bulletin, No. 3, pp. 144-145. (in Ukrainian).

${ }^{22}$ Lipkan V. A., Baskakov V. Yu. (2013) Administratyvno-pravovyj rezhym informaciji z obmezhenym dostupom v Ukrajini [Administrative and legal regime of sensitive information in Ukraine]. Kyiv: FOP O. P. Lipkan. pp. 164-165 (in Ukrainian).

${ }^{23}$ Kaliuzhnyi R. A., Kopan O. V., Martseniuk O. H. (2013) Teoretyko-metodologhichni zasady informacijnogho prava Ukrajiny: realizacija prava na informaciju [Theoretical and Methodological Principles of Information Law of Ukraine: Exercise of the Right to Information]. Kyiv: "MP Lesia". p. 181. (in Ukrainian). 
According to its nature the systematization process of normative legal acts involves their ordering, bringing into a certain harmonized system ${ }^{24}$.

\section{Improvement of information legislation norms}

A number of scientists R. A. Kaliuzhnyi, O. V. Kopan, O. H. Martseniuk, rightly affirm that the basis for systematization of information law norms should be worked out by legal science and proven by the fundamental principles: combination of traditions and innovations; incorporation of the norms of current information legislation of Ukraine into the new system through the aggregation of law institutions; formation of inter-branch institutions of law on the basis of relations with sectoral institutions ${ }^{25}$.

Information law means the system of laws of Ukraine, the current international agreements of Ukraine with the consent provided by the Verkhovna Rada of Ukraine, as well as the subordinate legal acts of Ukraine adopted in accordance with the Constitution of Ukraine governing public relations in the field of information ${ }^{26}$.

Taking into account the substantive elements (normative legal acts) during systematization, it is necessary to consider the normative acts (agreements, conventions) of international law ratified by Ukraine; to legalize positive practices in the field of information relations and norms of public morality, the universal human values defined by the United Nations in its Charter, the Declaration of Human Rights, European Union decisions and other generally accepted interstate normative acts being used as standards today, and which are used to define the civilization of not only a certain country but also the world community as a whole ${ }^{27}$.

In general, systematization of information legislation (systematization of laws and regulations about information) involves the purposeful activity of competent authorities or individuals in structuring, monitoring, researching,

${ }^{24}$ Krestovska N. M., Matvieieva L. H. (2015) Teorija derzhavy i prava. Pidruchnyk. Praktykum. Testy [The Theory of State and Law. Textbook. Case Study. Tests: textbook]. Kyiv: Yurinkom Inter. p. 384. (in Ukrainian).

${ }^{25}$ Kaliuzhnyi R. A., Kopan O. V., Martseniuk O. H. (2013) Teoretyko-metodologhichni zasady informacijnogho prava Ukrajiny: realizacija prava na informaciju [Theoretical and Methodological Principles of Information Law of Ukraine: Exercise of the Right to Information]. Kyiv: "MP Lesia". p. 182. (in Ukrainian).

${ }^{26}$ Lipkan V. A., Cherepovskyi K. P. (2014) Inkorporacija informacijnogho zakonodavstva Ukrajiny [Incorporation of Information Legislation of Ukraine]. Kyiv: FOP O. P. Lipkan. p. 134. (in Ukrainian).

${ }^{27}$ Kaliuzhnyi R. A., Kopan O. V., Martseniuk O. H. (2013) Teoretyko-metodologhichni zasady informacijnogho prava Ukrajiny: realizacija prava na informaciju [Theoretical and Methodological Principles of Information Law of Ukraine: Exercise of the Right to Information]. Kyiv: "MP Lesia". p. 183. (in Ukrainian). 
streamlining laws to improve the effectiveness of lawmaking, law enforcement and legal education concerning the information sphere of society $^{28}$.

At the first stage of improving information legislation, as noted by I. V. Aristov, it is necessary not to start immediately with its reformation, but develop a strategy for the formation of information legislation ${ }^{29}$.

For the most part, with regard to new branches, the subject of which has not yet been sufficiently defined, the most rational and adequate direction for improvement is to systematise regulatory legal material through incorporation and consolidation. The incorporation will play a function of accounting for regulatory legal materials, and consolidation should begin the process of further codification ${ }^{30}$.

V. A. Lipkan and K. P. Cherepovskyi believe that incorporation can be done according to institutional features reflected in the norms of the Constitution of Ukraine: where the term "information" and similar terms ("records", "messages", "data") are used, or information is part of categories (e.g. information security, environmental information, etc.), but other legislation is omitted in this approach, where information is the object of legal relationship ${ }^{31}$. There is a position regarding the use of structured information law institutions as criteria for incorporation ${ }^{32}$.

Unlike incorporation, consolidation involves the reworking of legal array, its unification, eliminates numerous regulatory acts, eliminates excessive fragmentation, helps to consolidate them and further implement codification.

Today, a significant number of scientists have developed draft Codes on the settlement of information relations (K. Bieliakov, M. Shvets and V. Bryzhko, H. Krasnostup, V. Lypkan, K. Cherepovskyi, V. Tsymbaliuk

${ }^{28}$ Lipkan V. A., Cherepovskyi K. P. (2014) Inkorporacija informacijnogho zakonodavstva Ukrajiny [Incorporation of Information Legislation of Ukraine]. Kyiv: FOP O. P. Lipkan. p. 140. (in Ukrainian).

${ }^{29}$ Aristova I. V. (2000) Derzhavna informacijna polityka: orghanizacijno-pravovi aspekty [State Information Policy: Organizational and Legal Aspects]. Kharkiv: University of Internal Affairs. p. 174. (in Ukrainian).

${ }^{30}$ Lipkan V. A., Zalizniak V. A. (2012) Systematyzacija informacijnogho zakonodavstva Ukrajiny [Systematization of Information Legislation of Ukraine]. Kyiv: FOP O. P. Lipkan. p. 178. (in Ukrainian).

${ }^{31}$ Lipkan V. A., Cherepovskyi K. P. (2014) Inkorporacija informacijnogho zakonodavstva Ukrajiny [Incorporation of Information Legislation of Ukraine]. Kyiv: FOP O. P. Lipkan. p. 169. (in Ukrainian).

${ }^{32}$ Shkarupa V., Tsymbaliuk V. (2006) Zastosuvannja polozhenj prava shhodo formuvannja osnov teoriji informacijnogho prava [Application of Legal Provisions to Form the Basis of Information Law Theory]. Legal Informatics. No. 3 (11). p. 46. (in Ukrainian). 
etc.) and presented to the public. There is also a draft Information Code developed by the State Committee on Information Policy, Television and Broadcasting of Ukraine.

Emphasizing the topicality of information relations in the modern world and in Ukraine, taking into account a number of problematic issues in the structure of drafts of such Information Codes, the requirements and standards of international law, the obligations of Ukraine regarding the process of its integration into the world community, as well as the sphere of legal regulation are taken into account ${ }^{33}$.

Carrying out systematization of information legislation will facilitate harmonization of its norms, improvement of conceptual and categorical apparatus, normalization of law enforcement activities in realization of information rights, information activities and, in general, establishment of level of relations in accordance with the requirements of modern information society. Regarding the peculiar activities of the SBGS, it is necessary to develop an Information Concept in the Sphere of Border Guarding.

Another direction for improving information relations is caused by the need to clarify the terminology and content of certain categories in the rules of information legislation. Only accurate and unambiguous terms and concepts will allow to most correctly formulate the content of a particular legal institution and ensure culture of legal regulation in a particular area of legal relations, as the production of standardized definitions in the law in general is one of the important tasks of lawmaking and overall legislative practice $^{34}$. In Ukraine, it is believed that the solution of problems of regulatory legal support of information relations is possible on the basis of situational response. Certain problems of legal regulation of public relations in this field are solved in separate laws and by-laws rather fragmentarily; a number of legal norms that directly or indirectly regulate public relations in the field of information and communication relations are not conceptually consistent $^{35}$. In this regard, O. A. Baronov notes that the work on the development of information law and the improvement of information

33 Bieliakov K. I. (2009) Orghanizacijno-pravove ta naukove zabezpechennja informatyzaciji v Ukrajini: problemy teoriji ta praktyky [Organizational, Legal and Scientific Support of Informatization in Ukraine: Problems of Theory and Practice]. Kyiv. p. 10. (in Ukrainian).

${ }^{34}$ Lytvyn N. A. (2018) Administratyvno-pravove zabezpechennja informacijnoji dijaljnosti orghaniv Derzhavnoji fiskaljnoji sluzhby Ukrajiny [Administrative and Legal Support of Information Activities of Bodies of the State Fiscal Service of Ukraine]. Irpin. p. 385. (in Ukrainian).

${ }^{35}$ Zhanhozha R. (2000) Do pytannja rozshyrennja informacijnogho prostoru Ukrajiny [On the Issue of Expansion of the Information Space of Ukraine]. Strategic Panorama. No. 3, pp. 203-206. p. 203 .(in Ukrainian). 
legislation has a significant prospect in view of the range and the importance of problems that occur in the information sphere ${ }^{36}$.

Lack of established terminology in the information legislation may cause refusal from the public administration to satisfy citizens' information rights, confusion in law enforcement activities, as well as subjectivism in addressing issues in the information sphere.

It is quite often that acting in their own interests or in the interests of third parties, officials refuse to give public information to citizens without reason, substituting categories that have not been clearly fixed in the current norms of information legislation, in particular by hiding behind such categories as "official information" or "lack of public interest". An example of this is the decision in Case 335/13988/17 by the Ordzhonikidze District Court in the lawsuit of the plaintiff to the Zaporizhzhia City Council, regarding the failure to provide the plaintiff as a requester of public information with copies of contracts with the winners in competitive tendering for house managers. The plaintiff who appealed to the Zaporizhzhia City Council for providing him with public information was denied on the grounds that this service required reimbursement of actual expenses and was not paid by the plaintiff. However, the requested information was of public interest, and no charge for copying and printing is required when providing a person with information about oneself and one of public interest. Therefore, the court upheld the plaintiff's claims ${ }^{37}$.

The intensive process of creating modern information legislation led to the emergence of new legal categories and terms. But it is not uncommon for the same terms to appear in different regulatory legal acts with different or ambiguous interpretations ${ }^{38}$.

Due to the fact that various laws and regulations governing public relations with information being the subject were adopted at different times without the agreement of the conceptual apparatus; they have a number of terms that are not correct enough, do not cause appropriate information reflection or do not have a clear definition of content at all. Terminological inaccuracies, different interpretations of similar concepts and categories with

${ }^{36}$ Baranov O. A. (2016) Naprjamy perspektyvnykh doslidzhenj u ghaluzi informacijnogho prava [Areas of Perspective Research in the Field of Information Law]. Information and Law, No. 2 (17), p. 15. (in Ukrainian).

${ }^{37}$ Decision of Ordzhonikidze District Court in Case No. 335/13988/17 2-a/335/58/2018 of March 6, 2018. URL : https://youcontrol.com.ua/catalog/court-document/72697946/. (accessed 25 October 2019).

${ }^{38}$ Baranov O. A. (2016) Naprjamy perspektyvnykh doslidzhenj u ghaluzi informacijnogho prava [Areas of Perspective Research in the Field of Information Law]. Information and Law, No. 2 (17), p. 29. (in Ukrainian). 
the same names and forms lead to their ambiguous understanding and application in practice. For example, with regard to information relations, such terms as "classified information", "secret", "document", "documented information", "property", "possession", "ownership", "intellectual property", "automated system", "subject of public relations", "participants in public relations", "system of information relations", etc. can be mentioned 39 .

The concept of "information about a natural person" requires clarification, which in Article 11 of the Law of Ukraine "On Information" is the same as "personal data". Subject to the laws of the European Union and in accordance with Regulation (EU) 2016/679 of the European Parliament and of the Council of May 04, 2016, "General Data Protection Regulation", the term "personal data" means any information, relating to an identified natural person ("data subject"). It should be emphasized that the EU Regulation uses the unambiguous term "personal data", in contrast to the Law of Ukraine "On Information", where "personal data" is identified with the concept of "information about a natural person" (Art. 11), causing confusion in law enforcement activities. These two categories require differentiation and refinement of content, and information about a person has a broader meaning than personal data.

In addition to the above, there are a number of problematic terminologies and categories of information legislation that need separate scientific development and are not exhausted within the scope of this research.

At the present stage of development of the information society, these aspects determine the theoretical necessity and practical expediency, timely securing the actual categories and terms of information legislation (according to the conditions of time and real needs) which are substantiated by the scientific doctrine of information law.

\section{Development of information support for information relations in SBGS activities}

The intensive use of information systems in the SBGS activities contributes to accelerating not only information processes but also the fulfilment of all tasks assigned to the border guard agency. However, the processing of information in such systems poses an additional threat to its integrity and security. Therefore, at the same time when data is entered, processed, and transmitted in information systems, it is necessary to constantly take measures to secure the content of information in order to

39 Tsymbaliuk V. S., Havlovskyi V. D., Hrytsenko V. V.et al. (2014) Osnovy informacijnogho prava Ukrajiny [Fundamentals of Information Law of Ukraine]. Kyiv: Znannia. p. 110. (in Ukrainian). 
ensure their functioning. Such measures should be comprehensive (legal, organizational, technical, control, prosecution, etc.) and implemented by all officials of the SBGS who have access to the information systems. There are special structural units designated to protect information within the activities of the Main Centre of Communication, Automation and Information Protection in the Administration of the State Border Guard Service of Ukraine where the best experts in the field of information protection are involved; their smooth operation as well as providing opportunities for their professional growth will improve the effectiveness of countering information threats in the research area ${ }^{40}$.

Moreover, the urgent issue today is the introduction of electronic identification of persons, which should be technically embodied and ensured in the practical activities of the SBGS.

Effective information activities of the SBGS depend not only on perfect normative and legal regulation, but also on organizational and methodological support. Its elements are the following: professionalism of the personnel carrying out information activities: knowledge of current information legislation and skills of its application; an appropriate educational program should be mastered within the SBGS; constant improvement of professional skills, abilities to solve complex problems and balance them with the legislation and new emerging threats in the sphere of border guarding; the level of information culture of all personnel and understanding of the integral border guard system by each serviceman influence the positive image of the border guard service; strict adherence to the basic norms, principles and ways of carrying out information activities in the SBGS; providing the management headquarters of the SBGS with timely, reliable, complete, essential, comprehensible information for making sound management decisions in the field of state border security; permanent and continuous implementation of security measures as to information processed in the SBGS information and telecommunication systems; control over compliance with the organization and implementation of security measures as to the information managed by the SBGS.

One of the problems of legal support of management in the SBGS bodies is the ineffective mechanism for providing the SBGS military and civil employees with the necessary legal information for management activities,

40 Kushnir I. P. (2018) Orghanizacijno-pravovi pytannja zabezpechennja zakhystu informaciji $v$ informacijnykh systemakh Derzhavnoji prykordonnoji sluzhby Ukrajiny [Organizational and Legal Issues of Information Security in Information Systems of the State Border Guard Service of Ukraine]. Carpathian Legal Bulletin, No. 3, pp. 81-84. p. 83. (in Ukrainian). 
which is quite topical in the context of development of the law enforcement agency and a shortage of specialists with legal education in the SBGS. One way to solve this problem is proposed by V. L. Zolka: to establish Legal Information Centres at all levels of command; to develop and approve a program for training and retraining of specialists in the field of information and analytical activities with the issues on information law included; make more effective use of existing information and telecommunication systems of the SBGS ${ }^{41}$.

\section{CONCLUSIONS}

Security of the state border of Ukraine is a complex and dynamic sphere of state activities. The border security system is shaped by different tasks and directions in the functioning of the SBGS, which are directly dependent on the border guard agency and (or) national tendency of development. One of the integrated components that depends on state regulation and departmental support is the information component of the SBGS activities, which finds manifestation in information relations.

The research showed that according to the current legislation and specificity of internal activities, the most regulated and considered areas is technical and organizational information support of the SBGS. But information relations also involve communication with the public on the exercise of their information rights in the sphere of border guarding. Thus, a considerable number of manifestations of information relations in the activities of the border guard agency are sufficiently regulated and mainly satisfy the information needs of all subjects of these relations, but there are some issues that need improvement.

The main lever of the problem gravitates toward the absence of a nationwide strategy for the development of the information society (in certain areas only: information security, cyber security, etc.) and systematization of information legislation. Taking into account this and the specifics of activities of the SBGS, the directions have been determined that will help to improve information relations and increase efficiency in the protection of the state border of Ukraine.

These directions are: systematization of information legislation norms; improvement of information law terminology; development of information

${ }^{41}$ Ziolka V. L. (2015) Okhorona nacionaljnykh interesiv Ukrajiny u prykordonnij sferi (administratyvno-pravovyj aspekt) [Protection of Ukraine's National Interests in the Sphere of Border Guarding (Administrative and Legal Aspect)]. Khmelnytskyi: NADPSU. p. 201. (in Ukrainian). 
support for information relations in the SBGS activities; building knowledge and awareness of the SBGS personnel.

Legal regulation of information activities of the SBGS is a system of legal means and methods by which influence on information relations in the field of border security is carried out, the model of behaviour for the realization of a certain type of information activities is formed.

Proper legal regulation and well-established departmental mechanism for organizing information activities in the SBGS will significantly improve the implementation of the state information policy, will promote the efficiency of obtaining, processing and protecting information which is managed by the border guard agency, will provide management activities with more purposefulness, validity, efficiency and effectiveness, comprehensive assurance of information rights of all subjects of information relations and will help to improve the border security and image of the SBGS in general.

\section{SUMMARY}

The article describes the directions for improving information relations in the activities of the SBGS.

Information relations, which are conditioned both by the internal organizational aspects of the information activities of the SBGS and the provision of information rights of citizens (within the competence), require timely coverage and regulation by legal acts, the creation and improvement of clear organizational mechanisms for information support and the adequate state of information security. The issue of improving information relations in the field of SBGS activities is closely related to the expected result, final impact and their impact on the state of border security.

General information tendencies in the development of modern information society, ongoing information war against Ukraine, European integration, change of threats on the state border, the need for increase of efficiency of border security: all these integrating factors conditioned the urgency of working out directions for improvement of information relations in activities of SBGS.

The researched information relations are sufficiently regulated and predominantly meet the information needs of all subjects of these relations, but there are some issues that need improvement. The main problems are caused by the lack of a national strategy for the development of information society and the systematization of information legislation. Taking into account this and the specifics of activities of the SBGS, the directions have been determined that will help to improve information relations and increase efficiency in the protection of the state border of Ukraine. These directions 
are: systematization of information legislation norms; improvement of information law terminology; development of information support of information relations in activities of the SBGS; formation of information knowledge and awareness of personnel of the SBGS.

\section{REFERENCES}

1. Main Directions of Activities and Further Development of SBGS of Ukraine in 2019. URL: dpsu.gov.ua/upload/Haprjami_ДПСУ Optimized.pdf. (accessed 11 October 2019).

2. Kaliuzhnyi R. A., Kushnir I. P. (2015) Pravove zabezpechennja vzajemodiji publichnoji administraciji u prykordonnij sferi [Legal Support for Public Administration Interaction in the Sphere of Border Guarding]. Kyiv: "MP Lesia". (in Ukrainian).

3. Liashuk R. M., Kushnir I. P. (2017) Rezuljtatyvnistj ta efektyvnistj v dijaljnosti orghaniv okhorony derzhavnogho kordonu Ukrajiny [Effectiveness and Efficiency in Activities of the State Border Protection Bodies of Ukraine]. Law and Society, No. 5, pp. 154-159. (in Ukrainian).

4. Kushnir I. P. (2018) Analiz zmistu ponjattja «bezpeka derzhavnogho kordonu» [Content Analysis of "State Border Security" Concept]. Bulletin of the Southern Regional Centre of the National Academy of Law Sciences of Ukraine,. No. 16, pp. 75-81. (in Ukrainian).

5. Maksymenko Yu. Ye. (2014) Normatyvno-pravove reghuljuvannja informacijnykh vidnosyn $v$ Ukrajini: stan ta perspektyvy [Legal Regulation of Information Relations in Ukraine: Status and Prospects]. Legal Bulletin, No. 3, pp. 142-146. (in Ukrainian).

6. Plan of Measures for Realization of the Strategic Course of the State to Acquire Full Membership of Ukraine in the European Union and in the North Atlantic Treaty Organization: by Presidential Decree No. 155/2019 of April 20, 2019. URL: https://www.president.gov.ua/documents/155201926586. (accessed 18 October 2019).

7. On the decision of the National Security and Defence Council of Ukraine of December 29, 2016 "On the Doctrine of Information Security of Ukraine": Presidential Decree of February 25, 2017 No. 47/2017. Official Bulletin of the President of Ukraine. 2017. No. 5. Art. 102.

8. Development of the system of risk analysis in the State Border Guard Service of September 19, 2017. URL : http://dpsu.gov.ua/ua/rozvitoksistemi-analizu-rizikiv-derzhprikordonsluzhbi-/. (accessed 4 October 2019).

9. "On Border Control": Law of Ukraine of November 5, 2009. Bulletin of the Verkhovna Rada of Ukraine. 2010. No. 6. Art. 46. 
10. On Approval of the Procedure for Entering and Leaving Temporarily Occupied Territory of Ukraine (as amended): Resolution of the Cabinet of Ministers of Ukraine of June 4, 2015. No. 367. URL: http://zakon5.rada.gov.ua/laws/show/367-2015-\%D0\%BF. (accessed 20 October 2019).

11. Cyber Security Strategy of Ukraine: Presidential Decree No. 96/2016 of March 15, 2016. Uriadovyi Kurier. 2016. No. 52.

12. Draft Decree of the President of Ukraine on Approval of the Strategy for the Development of Information Space of Ukraine for the Period up to 2020. URL : http://comin.kmu.gov.ua/control/uk/publish/ article?art_id=113102\&cat_id=61025. (accessed 12 October 2019).

13. Kushnir I. P. (2018) Informacijno-pravova dijaljnistj Derzhavnoji prykordonnoji sluzhby Ukrajiny: normatyvno-pravovyj aspekt [Information and Legal Activities of the State Border Guard Service of Ukraine: Regulatory Aspect]. Constitutional and Legal Academic Studies, No. 2, pp. 165-170. (in Ukrainian).

14. On Approval of the State Border Guard Service Development Strategy: Decree of the Cabinet of Ministers of Ukraine of November 23, 2015. No. 1189-r. Uriadovyi Kurier. 2015. No. 220.

15. Shepeta V. O. (2012) Administratyvno-pravovi zasady tekhnichnogho zakhystu informaciji [Administrative and Legal Principles of Technical Protection of Information]. Kyiv: FOP O. P. Lipkan. (in Ukrainian).

16. Aristova I. V. (2000) Derzhavna informacijna polityka: orghanizacijno-pravovi aspekty [State Information Policy: Organizational and Legal Aspects]. Kharkiv: University of Internal Affairs. (in Ukrainian).

17. Maksymenko Yu. Ye. (2007) Teoretyko-pravovi zasady zabezpechennja informacijnoji bezpeky Ukrajiny [Theoretical and Legal Principles for Ensuring Information Security of Ukraine]. Kyiv. (in Ukrainian).

18. Lipkan V. A., Baskakov V. Yu. (2013) Administratyvno-pravovyj rezhym informaciji z obmezhenym dostupom v Ukrajini [Administrative and legal regime of sensitive information in Ukraine]. Kyiv: FOP O. P. Lipkan. (in Ukrainian).

19. Kaliuzhnyi R. A., Kopan O. V., Martseniuk O. H. (2013) Teoretyko-metodologhichni zasady informacijnogho prava Ukrajiny: realizacija prava na informaciju [Theoretical and Methodological Principles of Information Law of Ukraine: Exercise of the Right to Information]. Kyiv: "MP Lesia" (in Ukrainian). 
20. Krestovska N. M., Matvieieva L. H. (2015) Teorija derzhavy $i$ prava. Pidruchnyk. Praktykum. Testy [The Theory of State and Law. Textbook. Case Study. Tests: textbook]. Kyiv: Yurinkom Inter. (in Ukrainian).

21. Lipkan V. A., Cherepovskyi K. P. (2014) Inkorporacija informacijnogho zakonodavstva Ukrajiny [Incorporation of Information Legislation of Ukraine]. Kyiv: FOP O. P. Lipkan. (in Ukrainian).

22. Lipkan V. A., Zalizniak V. A. (2012) Systematyzacija informacijnogho zakonodavstva Ukrajiny [Systematization of Information Legislation of Ukraine]. Kyiv: FOP O. P. Lipkan. (in Ukrainian).

23. Shkarupa V., Tsymbaliuk V. (2006) Zastosuvannja polozhenj prava shhodo formuvannja osnov teoriji informacijnogho prava [Application of Legal Provisions to Form the Basis of Information Law Theory]. Legal Informatics. No. 3 (11). p. 44-51. (in Ukrainian).

24. Bieliakov K. I. (2009) Orghanizacijno-pravove ta naukove zabezpechennja informatyzaciji $v$ Ukrajini: problemy teoriji ta praktyky [Organizational, Legal and Scientific Support of Informatization in Ukraine: Problems of Theory and Practice]. Kyiv. (in Ukrainian).

25. Lytvyn N. A. (2018) Administratyvno-pravove zabezpechennja informacijnoji dijaljnosti orghaniv Derzhavnoji fiskaljnoji sluzhby Ukrajiny [Administrative and Legal Support of Information Activities of Bodies of the State Fiscal Service of Ukraine]. Irpin. (in Ukrainian).

26. Zhanhozha R. (2000) Do pytannja rozshyrennja informacijnogho prostoru Ukrajiny [On the Issue of Expansion of the Information Space of Ukraine]. Strategic Panorama. No. 3, pp. 203-206. (in Ukrainian).

27. Baranov O. A. (2016) Naprjamy perspektyvnykh doslidzhenj $u$ ghaluzi informacijnogho prava [Areas of Perspective Research in the Field of Information Law]. Information and Law, No. 2 (17), p. 15-31. (in Ukrainian).

28. Decision of Ordzhonikidze District Court in Case No. 335/13988/17 2-a/335/58/2018 of March 6, 2018. URL : https://youcontrol.com.ua/catalog/court-document/72697946/. (accessed 25 October 2019).

29. Tsymbaliuk V. S., Havlovskyi V. D., Hrytsenko V. V.et al. (2014) Osnovy informacijnogho prava Ukrajiny [Fundamentals of Information Law of Ukraine]. Kyiv: Znannia. (in Ukrainian).

30. Kushnir I. P. (2018) Orghanizacijno-pravovi pytannja zabezpechennja zakhystu informaciji $v$ informacijnykh systemakh Derzhavnoji prykordonnoji sluzhby Ukrajiny [Organizational and Legal Issues of Information Security in Information Systems of the State Border 
Guard Service of Ukraine]. Carpathian Legal Bulletin, No. 3, pp. 81-84. (in Ukrainian).

31. Ziolka V. L. (2015) Okhorona nacionaljnykh interesiv Ukrajiny $u$ prykordonnij sferi (administratyvno-pravovyj aspekt) [Protection of Ukraine's National Interests in the Sphere of Border Guarding (Administrative and Legal Aspect)]. Khmelnytskyi: NADPSU. (in Ukrainian).

Information about the author: Iryna Kushnir, Candidate of Law Sciences (Ph.D), doctoral candidate of higher doctorate of the National Academy of the State Border Guard Service of Ukraine named after Bohdan Khmelnytskyi, 46 Shevechenko str. Khmelnitskyi, Ukraine ORCID ID: orcid.org/0000-0003-0286-7591 
DOI https://doi.org/10.36059/978-966-397-159-9/109-127

\section{CERTAIN ASPECTS OF UKRAINIAN BORDER SECURITY MECHANISM FUNCTIONING}

\section{Pavlo Volynets}

\section{INTRODUCTION}

The issue of effective national security protection of Ukraine arises particularly acute, especially in the border sphere under the conditions of a hybrid war pursuance in the east of Ukraine.

The protection of national sovereignty and territorial integrity of Ukraine, ensuring its economic and information security as the most important functions of the state, the matter of the entire Ukrainian people in accordance with Article 17 of the Constitution of Ukraine are determined as main tasks of national security ${ }^{1}$. Thus, the legislator clearly defines the importance of the function to ensure the security of a man, society and the state and Article 17, Paragraph 3 of the Constitution of Ukraine states that the state security provision and protection of the state border of Ukraine are entrusted with the respective military formations and law enforcement bodies of the state, the organization and rules of procedure of which are determined by the law ${ }^{2}$. From the above provisions of the highest law of Ukraine, it follows that the security of the state border is an integral component of the existence of Ukraine's national security as a state. Therefore, the security of the state border is one of the most important functions of the state.

It should be noted that the issues of national security protection of Ukraine are widely covered in scientific and specialized literature. In recent years, there has been a sharp increase in scientific publications on the subject given the actual hybrid war Ukraine happened to find itself in 2014.

\footnotetext{
${ }^{1}$ Konstytutsiia Ukrainy: Zakon Ukrainy vid 28.06.1996 № 254k/96-VR. Data onovlennia: 30.09.2016. URL: http://zakon3.rada.gov.ua/laws/main/254k/96-vr. (data zvernennia 23.05.2019 roku).

${ }^{2}$ Konstytutsiia Ukrainy: Zakon Ukrainy vid 28.06.1996 № 254k/96-VR. Data onovlennia: 30.09.2016. URL: http://zakon3.rada.gov.ua/laws/main/254k/96-vr. (data zvernennia 23.05.2019 roku).
} 
Thus, the issue of state administration in the field of national security of Ukraine was studied by Sytnyk H. P., ${ }^{3}$ Tsevelov O. Ye., Zhuk S. M. ${ }^{4}$ studied topical issues of ensuring border security of Ukraine within the national security system.

A. F. Melnyk paid attention to the regularities and peculiarities of the state mechanisms functioning within the system of national security of Ukraine $^{5}$. The issue of the border security mechanisms functioning in the context of the theory of integrated border management was studied by Lytvyn M. M. ${ }^{6}$

Kuprienko D. A. studied the role of the State Border Guard Service of Ukraine within the state mechanism of border security, as well as the problems of forming a categorical and conceptual apparatus for border security $^{7}$. The issue of decomposition of threats and dangers to the national security of the state in the border sphere was studied by Babii Yu.

However, the role and place, as well as the peculiarities of the operational and search component of the state mechanism of ensuring the border security of Ukraine in the conditions of its active formation and transformation, remain unclear.

The purpose of our research is to study the individual aspects of the functioning of the mechanism for ensuring border security, justify the role and place of the operational and investigative component in it, taking into account the determination of views upon the role and place of the State Border Service of Ukraine in it.

The following methods have been used in the process of the research to achieve the purpose and to solve scientific problems: systematic analysis, analogy, comparison in the process of undertaking analysis of scientific and specialized literature, as well as legislative instruments on national security

${ }^{3}$ Sytnyk G. P. (2012) Derzhavne upravlinnja u sferi nacionaljnoji bezpeky (konceptualjni ta orghanizacijno-pravovi zasady) [Public administration in the field of national security (conceptual and organizational and legal bases)]. Kyiv : NADU. (in Ukrainian).

${ }^{4}$ Tsevelov O. Ye., Zhuk S. M. (2017) Aktualni pytannia zabezpechennia prykordonnoi bezpeky Ukrainy u systemi natsionalnoi bezpeky [Topical issues of ensuring the border security of Ukraine in the national security system].Investments : practice and experience, no10,pp.8890. (in Ukrainian).

5 Melnyk A.F., Obolenskyi Yu.A., Vasyna A.Yu. (2014) Derzhavne upravlinnia [Governance] / A.F. Melnyk (ed). Kyiv : Znannia. (in Ukrainian).

6 Lytvyn M. M. (2012) Intehrovane upravlinnia kordonamy [Integrated border management]. Khmelnytsky : NADPSU. (in Ukrainian).

7 Kuprijenko D. A. (2014) Osnovni ponjattja ta kateghoriji u sferi zabezpechennja prykordonnoji bezpeky [Basic concepts and categories in the field of border security].Collection of scientific papers of the National Academy of the State Border Guard Service of Ukraine. Series: Military and Technical Sciences, no. 1(64), pp. 357-368.(in Ukrainian). 
and operational and investigative activity, identification of generalization and data structuring to determine the main, generalized functions of the national mechanism of ensuring the border security of Ukraine, the synthesis of individual functions of operational and search activity actors in order to determine their place and role within system of the national mechanism of ensuring the border security of Ukraine.

\section{Justification of the content of the concept of border security mechanism}

The complexity of the concept definition of the mechanism of border security of Ukraine ensuring is stipulated by: first, significant content and functional load of its components; secondly, the lack of a well-established conceptual apparatus, which defines the peculiarities of different types of activities in the sphere of border security of Ukraine, the difficulties associated with ensuring the effective joint activity of different actors, etc.

According to the explanatory dictionary of the Ukrainian language, the mechanism is an internal structure, the system of something ${ }^{8}$. Usually, the term mechanism includes not only the components of the internal component of anything, but also describes the principles and order of their interaction with each other and with the external environment. Melnyk A. F., in the context of studying the laws of functioning of state-power mechanisms, in particular notes that state administration is one of the types of activity for the exercise of state power (along with law-making and justice), which consists in the practical implementation of organizational, executive and administrative functions in order to enforce the requirements of the legislation and to exercise managerial influence over certain objects thereupon ${ }^{9}$.

According to Morchenko M. N. one should understand the term of "State mechanism" as the system of different state bodies, organizations, materiel resources of state power and management, the armed forces ${ }^{10}$. Thus, A. P. Prytula defines the constituent mechanism of the state as the so-called material appendage, which includes the police, penitentiary institutions,

${ }^{8}$ Slovnyk ukrajinsjkoji movy: Akademichnyj tlumachnyj slovnyk ukrajinsjkoji movy [Dictionary of the Ukrainian Language: Academic Interpretative Dictionary of the Ukrainian Language].Retrieved from:https://sim.in.ua.mekanizm (accessed21 May 2019). (in Ukrainian).

9 Melnyk A.F., Obolenskyi Yu.A., Vasyna A.Yu. (2014) Derzhavne upravlinnia [Governance] / A.F. Melnyk (ed). Kyiv : Znannia. (in Ukrainian).

${ }^{10}$ Marchenko M.N. (2014). Teoriya gosudarstva i prava[Theory of government and rights]/ V. K. Babaeva (ed.). Moskva : Yurayt. (in Russian).. 
security agencies, the armed forces and other law enforcement agencies of the state ${ }^{11}$.

Also, Melnyk A. F. notes that the role of the state power in the course of the elaboration of the state-administrative mechanisms is conditioned by its functions within the system of state administration, and by the extent to which they ensure the implementation of the functions of the management system $^{12}$.

Thus, in the general perception one can qualify the state mechanisms as the systems of state authorities and local self-government bodies, which, with the help of certain tools, realize the influence (interference) upon certain spheres of life in order to achieve the goals of state policy within certain spheres of life of society and the state.

When it comes to social mechanisms it is necessary to clearly define the following main components of it, namely: the purpose of mechanisms (to solve what tasks they are aimed at); the internal structure of the mechanism (which consists of certain actors that perform the tasks of the mechanism alone or in interaction); the actors of the mechanism (elements of its internal construction, as well as the main driving forces in solving problems); the role and place of the mechanism within the social system (the relative weight of the mechanism in solving specific social problems, as well as the peculiarities of its interaction with the environment); functions of the (set of specific tools used in accordance with certain procedures), etc.

Considering the above, the state security mechanism is a system of state authorities and local self-government bodies that, through certain tools, realize the influence (interference) into the sphere of state security in order to eliminate threats.

Sytnyk H. P. studying the issue of forming and assessing the effectiveness of security mechanisms determines that they should be considered in two aspects:

- ontological, when the basis for the conclusions on the foundations of this mechanism consists in the objective properties and qualities of materia that exist regardless of human consciousness;

11 Prytula A.M. (2019) Taktyko-pravovi zasady operatyvno-sluzhbovoi diialnosti Derzhavnoi prykordonnoi sluzhby Ukrainy : monohrafiia [Tactical and legal principles of the operational service of the State border service of Ukraine : monograph]. Odesa : Feniks. (in Ukrainian)..

12 Melnyk A.F., Obolenskyi Yu.A., Vasyna A.Yu. (2014) Derzhavne upravlinnia [Governance] / A.F. Melnyk (ed). Kyiv : Znannia. (in Ukrainian). 
- epistemological, when the basis of these conclusions consists in the generally accepted truths (laws), established by human beings at this stage of science development and formed on this basis their subjective assessments ${ }^{13}$.

It is important to identify the most important elements of the content of the concept of national security. Thus, according to the Law of Ukraine "On National Security", the national security of Ukraine is determined as the protection of state sovereignty, territorial integrity, democratic constitutional order and other national interests of Ukraine against real and potential threats ${ }^{14}$.

Therefore, the national security system should provide for effective protection against various types of threats. According to the new explanatory dictionary of the Ukrainian language, the term "Type" is defined as a separate field of work, occupancy, variety in a number of subjects, phenomena, etc. as well as a subsection that integrates a number of subjects, phenomena on common grounds and is part of the general higher section ${ }^{15}$.

On the basis of the analysis of the legislation, as well as the scientific and specialized literature devoted to the problem of national security, it is possible to determine the national-level security structure of Ukraine by its types (proposed in Figure 1).

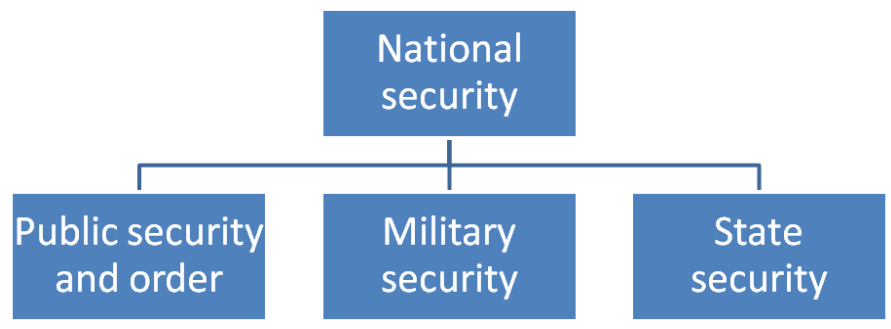

Fig. 1. Types of security

\footnotetext{
${ }^{13}$ Sytnyk G. P. (2012) Derzhavne upravlinnja u sferi nacionaljnoji bezpeky (konceptualjni ta orghanizacijno-pravovi zasady) [Public administration in the field of national security (conceptual and organizational and legal bases)]. Kyiv : NADU. (in Ukrainian).

${ }^{14}$ Pro natsionalnu bezpeku Ukrainy: Zakon Ukrainy vid 21.06.2018 Vidomosti Verkhovnoi Rady (VVR), 2018, № 31, st.241 URL: https://zakon.rada.gov.ua/laws/show/2469-19 (data zvernennia 18.06.2019 roku).

${ }^{15}$ Novyi tlumachnyi slovnyk ukrainskoi movy u trokh tomakh (2008) [A new interpretative dictionary of the Ukrainian language in three volumes]. Kyiv: Akonit.Vol. 1. P. 202. (in Ukrainian).
} 
Article 1 of the Law of Ukraine "On National Security" defines the terms: national security, military security, state security, as well as public security and order. In such a manner, according to the definitions of the law:

military security is the protection of state sovereignty, territorial integrity and democratic constitutional order and other vital national interests against military threats;

state security is the protection of state sovereignty, territorial integrity and democratic constitutional order and other vital national interests against real and potential threats of a non-military nature;

public security and order is the protection of vital for the society and the person interests, rights and freedoms of the individual and the citizen, insurance of which is the priority task in the activity of the security forces, other state authorities, local self-government bodies, their officials and the public, who carry out concerted efforts for implementation and protection of national interests from the effect of threats ${ }^{16}$.

The results of studies of national security problems by national scientists convincingly show that the security structure shown in Figure 1 is not exhaustive, since it covers the issue of protection of the basic vital interests of the individual, society and the state only against common types of threats. However, the multifaceted nature of life, and as a result of the variety of threats and challenges (which in turn are constantly transformed), require the identification of other special types of national security.

Consequently, the national legislation provides other formulations of types of security. According to the law of Ukraine "On National Police", ensuring public security is one of the areas of activity of the national police of Ukraine ${ }^{17}$. However, the law does not provide a clear definition of these definitions, which forms different scientific approaches to understanding the content of public security, which significantly expands the scientific views on the topic.

In such a manner, Panova O. O. believes that "in the broad sense, public security is a set of social relations regulated by the body of norms (both legal and customary) that influence an indefinite circle of persons in order to create an atmosphere of inward peace, security, trust. In its narrow sense,

\footnotetext{
${ }^{16}$ Pro natsionalnu bezpeku Ukrainy: Zakon Ukrainy vid 21.06.2018 Vidomosti Verkhovnoi Rady (VVR), 2018, № 31, st.241 URL: https://zakon.rada.gov.ua/laws/show/2469-19 (data zvernennia 18.06.2019 roku).

${ }^{17}$ Pro Natsionalnu politsiiu Ukrainy: Zakon Ukrainy vid 02.07.2015 № 580-VIII. Data onovlennia: 06.02.2018. URL: http://zakon5.rada.gov.ua/laws/show/580-19. (data zvernennia 10.02.2019 roku).
} 
public security is a set of social relations regulated by the legal propositions aimed at preventing threats to the population ${ }^{18}$.

Abroskin V. V. considering the term "public security" in general, thinks that "public security should be understood as legally regulated public relations, within which authorized by the state bodies and persons carry out activities aimed at preventing and termination of unlawful encroachments, natural and man-made emergencies, minimizing their negative consequences in order to maintain the state of protection of the rights, freedoms and interests of individuals and legal entities, society and the state." He also believes that this definition should be legally enshrined in the national legal boundaries ${ }^{19}$.

Going part way with the author, we believe that according to the author's definition of the content of public security, it covers certain vital areas of public life, and therefore, in its content, represents a certain area of national security.

A sphere is a set of conditions, an environment in which something happens; the area of physical or spiritual life, human or social activity ${ }^{20}$.

In our opinion, the sphere of national security include: border security, environmental security, ethno-political security, international security, cyber security, economic security, information security, etc.

Spheres of national security are presented in the figure (Fig. 2).

It should be noted that the list of national security spheres is not exhaustive, as threats have a tendency to transform. The constant transformation of views upon the substantive content of the national security system takes place against the backdrop of real and potential threats analysis. Therewith, the threat is considered as the possibility or inevitability of the emergence of something dangerous, annoying ${ }^{21}$, in other words, the potential risk of some harm.

${ }^{18}$ Panova O.O. (2017) Informatsiine zabezpechennia publichnoi bezpeky v Ukraini [Public security information in Ukraine]. Actual problems of domestic jurisprudence, vol. 2, no.6,p.126.

${ }_{19}$ Abroskyn V.V. (2019) Administratyvno-pravovi zasady zabezpechennia Natsionalnoiu politsiieiu Ukrainy publichnoi bezpeky $\mathrm{v}$ umovakh antyterorystychnoi operatsii : monohrafiia [Administrative and legal principles of ensuring public security in the conditions of anti-terrorist operation by the national police of ukraine: monograph]. Kharkiv: Folio. (in Ukrainian).

${ }^{20}$ Novyi tlumachnyi slovnyk ukrainskoi movy u trokh tomakh (2008) [A new interpretative dictionary of the Ukrainian language in three volumes]. Kyiv : Akonit.Vol. 3.P.489. (in Ukrainian).

${ }^{21}$ Novyi tlumachnyi slovnyk ukrainskoi movy u trokh tomakh (2008) [A new interpretative dictionary of the Ukrainian language in three volumes]. Kyiv: Akonit.Vol. 1. P. 202. (in Ukrainian).. 


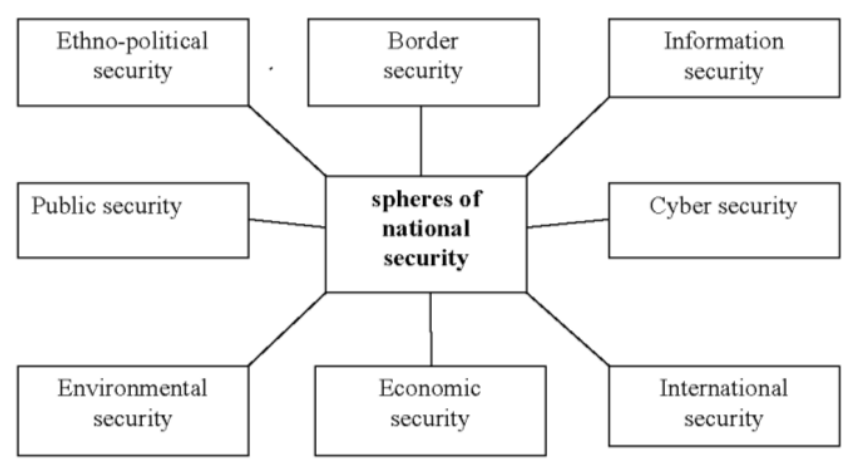

Fig. 2 Spheres of national security

Since 2014, after the Crimea annexation by the Russian Federation and the unleashing of the so-called hybrid war in the east of Ukraine, the process of radical reconsideration of the place and the importance of effective counteraction to the threats to the national security system of Ukraine has begun. According to the analytical report of the National Institute for Strategic Studies since the beginning of large-scale aggression by the Russian Federation, it has become apparent that the current form of the national security system is not able to perform its functions effectively. The country is now facing with extremely complex challenges, as it must carry out a comprehensive reform of the national security system and effectively overcome corruption in a short time, with significantly limited means, while at the same time providing for protection of fundamental national values such as independence, territorial integrity, state sovereignty, protection of rights and human freedoms, the rule of law, prosperity, peace and security ${ }^{22}$.

Different scientists and scientific schools use various basic concepts in the process of defining the spheres of national security. So, Vlasiuk O. S. distinguishes the following areas of national security: political, economic, socio-demographic, military, religious relations, information ${ }^{23}$.

Considering the concept of national security in the border sphere as border security Lytvyn M. M. defines that border security is a specific type

22 Conceptual frame work for development of the National security system of Ukraine(2015) Analytical report the National Institute for Strategic Studies.KyivRetrieved from:http://en.niss.gov.ua/public/File/docs/national_security_final.pdf.

${ }^{23}$ Vlasiuk O. S. (2016) Natsionalna bezpeka Ukrainy: evoliutsiia problem vnutrishnoi polityky [National security of Ukraine: the evolution of domestic policy issues]. Kyiv : NISD. (in Ukrainian).. 
of national security, which is defined as the state of protection of vital interests of the individual, society and the state in the border sphere ${ }^{24}$.

According to Kuprienko D. A., border security is a component of national security that has internal and external dimensions, which gives reason to speak about its systemic character. Considering this, the concept of "border security ensuring" should be understood as a systematic activity of state bodies, public institutions and individual citizens, aimed at the reliable protection of the national interests of the country from external and internal threats that appear in the border sphere and their effective counteraction ${ }^{25}$.

Scientists Tsevelov O. Ye. and Zhuk S. M., among other things, state that border security should include the following elements: scientific theory, conceptual foundation, policy, strategy and tactics, a complex of state and public institutions and organizations providing border security, and facilities for its ensuring ${ }^{26}$.

Shchokiv V. H. studying the specified range of problems in the context of national security management determines that national security management should form an optimal system of state-political institutions with effective coordination and distribution of functions of government agencies ${ }^{27}$.

The actors of the national security mechanism are certain military formations and law enforcement agencies reduced to the security and defence sector.

According to Article 12 of the Law of Ukraine "On National Security" the security and defence sector includes: Ministry of Defence of Ukraine, Armed Forces of Ukraine, State Special Service of Transport, Ministry of Internal Affairs of Ukraine, National Guard of Ukraine, National Police of Ukraine, State Border Guard Service of Ukraine, State Migration Service of Ukraine, State Emergency Service of Ukraine, Security Service of Ukraine, State Guard Service of Ukraine, State Service for Special Communication and Information Protection of Ukraine, the apparatus of the National

24 Lytvyn M. M. (2012) Intehrovane upravlinnia kordonamy [Integrated border management]. Khmelnytsky : NADPSU. (in Ukrainian).. 416p. p.14.

${ }^{25}$ Kuprijenko D. A. (2014) Osnovni ponjattja ta kateghoriji u sferi zabezpechennja prykordonnoji bezpeky [Basic concepts and categories in the field of border security]. Collection of scientific papers of the National Academy of the State Border Guard Service of Ukraine. Series: Military and Technical Sciences, no. 1(64), pp. 357-368.(in Ukrainian).

${ }^{26}$ Tsevelov O. Ye., Zhuk S. M. (2017) Aktualni pytannia zabezpechennia prykordonnoi bezpeky Ukrainy u systemi natsionalnoi bezpeky [Topical issues of ensuring the border security of Ukraine in the national security system].Investments : practice and experience, no10,pp.8890. (in Ukrainian).

${ }^{27}$ Shchokin H. V., Holovatyi M. F., Antoniuk O. V., Sladkevych V. P. (ed.)(2007) Menedzhment [Management]. Kyiv : MAUP. (in Ukrainian).. 
Security and Defence Council of Ukraine, the intelligence agencies of Ukraine, the central executive authority that provides for the formation and implementation of the state military-industrial policy ${ }^{28}$.

However, functionally, the security ensuring mechanism should take into account the ability to involve in the implementation of its own functions additional actors that may be involved on a temporary, periodic or episodic basis. Therefore, the law also states that "Other state authorities and local government bodies carry out their national security functions in cooperation with the bodies belonging to the security and defence sector" 29 .

Thus, the legislator determines that the security and defence sector of Ukraine consists of four interconnected components: security forces; defence forces; defence-industrial complex; citizens and civic associations voluntarily involved in national security ${ }^{30}$.

On the basis of the foregoing, it is possible to identify mechanisms for ensuring the border security of Ukraine as an activity of government agencies and local self-government bodies, military formations and law enforcement agencies, which, together with the involvement of the industrial and economic complex, as well as the entire Ukrainian people, implements a system of measures to protect the interests of the individual, society and the states within the border sphere.

At the same time, the border sphere is defined as a specific branch of international and internal public relations, concerning the issues of contractual legal formulation of the state border, maintaining legal relations in it, as well as a special area of activity of the actors of state administration concerning the border policy implementation ${ }^{31}$.

The main actors of the national-level border security mechanism are the Ministry of Internal Affairs of Ukraine, which ensures the formation and implementation of state policy in the field of protection of the state border of

\footnotetext{
${ }^{28}$ Pro natsionalnu bezpeku Ukrainy: Zakon Ukrainy vid 21.06.2018 Vidomosti Verkhovnoi Rady (VVR), 2018, № 31, st.241 URL: https://zakon.rada.gov.ua/laws/show/2469-19 (data zvernennia 18.06.2019 roku).

${ }^{29}$ Pro natsionalnu bezpeku Ukrainy: Zakon Ukrainy vid 21.06.2018 Vidomosti Verkhovnoi Rady (VVR), 2018, № 31, st.241 URL: https://zakon.rada.gov.ua/laws/show/2469-19 (data zvernennia 18.06.2019 roku).

${ }^{30}$ Pro natsionalnu bezpeku Ukrainy: Zakon Ukrainy vid 21.06.2018 Vidomosti Verkhovnoi Rady (VVR), 2018, № 31, st.241 URL: https://zakon.rada.gov.ua/laws/show/2469-19 (data zvernennia 18.06.2019 roku).

31 Lytvyn M. M. (2012) Intehrovane upravlinnia kordonamy [Integrated border management]. Khmelnytsky : NADPSU. (in Ukrainian). 416p.
} 
Ukraine and protection of Ukraine's sovereign rights in its exclusive (maritime) economic zone ${ }^{32}$.

The State Border Service of Ukraine directly implements the state policy within the security sphere of the state border of Ukraine and protection of the sovereign rights of Ukraine in its exclusive (maritime) economic zone.

However, effectiveness in the resolution of issues concerning border security ensuring by Ukraine is achieved through the independent and joint as well as coordinated efforts of the Ukrainian security and defence forces acting in the performance of their assigned tasks. However, given the extreme diversification of the spheres of activity of these actors, there are a number of problems in ensuring the effective management of the border security mechanism. The controller of the working efficiency of the state border security mechanism is its ability to respond adequately and in a timely manner to emerging threats.

\section{Threats as a factor of impact upon the state mechanism of border security of Ukraine}

Lytvyn M. M. noted that the establishment and functioning of the border security system is based on certain laws. First of all, it depends upon its construction, the nature of the threats, and efficiency and legal capability depends upon the economic potential of the state. The real perception and analysis of threats and risks, their proper classification and assessment is a compulsory condition therewith ${ }^{33}$.

As a result of intensification of various contradictions, both internal and external threats are created, the rise of which is given by foreign states (groups of states), individual social groups, citizens, processes and phenomena in different spheres of human life and activities, societies and states $^{34}$.

Border security threats can be identified in some way by examining the tasks performed by the State Border Guard Service of Ukraine within the system of integrated border management in cooperation with other national and foreign agencies and organizations. Among these tasks are: legal and

\footnotetext{
${ }^{32}$ Pro natsionalnu bezpeku Ukrainy: Zakon Ukrainy vid 21.06.2018 Vidomosti Verkhovnoi Rady (VVR), 2018, № 31, st.241 URL: https://zakon.rada.gov.ua/laws/show/2469-19 (data zvernennia 18.06.2019 roku).

${ }^{33}$ Lytvyn M.M. Aktualni pytannia zabezpechennia prykordonnoi bezpeky Ukrainy v suchasnykh umovakh derzhavotvorennia [Topical issues of ensuring the border security of Ukraine in modern conditions of state formation] Retrieved from:https://dpsu.gov.ua > upload > file > golova_11(accessed 10 Octover 2019). (in Ukrainian).

${ }^{34}$ Horbulin V.P., Kachynskyi A.B. (2009) Zasady natsionalnoi bezpeky Ukrainy[National security principles of Ukraine]. Kyiv : Intertekhnolohiia.P. 136. (in Ukrainian).
} 
regulatory framework in the field of integrated border management; ensuring cooperation in combating cross-border and transnational crime; control of the entry and stay of foreigners and stateless persons in Ukraine in accordance with European standards; information management and risk analysis; implementation of European standards for border, customs and other controls; facilitation of international economic activity and development of international trade, improvement of the state transit capacity; improving the customs administration system and improving the quality of customs regulation ${ }^{35}$.

Thus, Babii Yu. A., studying the threats to the national security of the state in the border sphere, defines the following ones: the spread of corruption, bribery; infringement of inviolability of the state border and the territorial integrity of the country; existing and potential territorial requirements on the part of foreign states; incompleteness of the contractual legal registration of the state border; ethnic autonomization of certain regions of Ukraine; inadequacy of the capabilities of the border control authorities, the nature and extent of the threats ${ }^{36}$.

Considering the international experience on these issues, it is necessary to note the separate opinions of public associations of human rights agencies i.e. according to experts of the Brennan Justice Centre in New York, one of the main threats to national security is the concealment of information from the public, as well as the presence of secret regulatory and legal framework in the state. In their opinion, systematic secrecy in dealing with national security issues undermines the foundations of democratic self-government ${ }^{37}$.

These and other scientific studies and socio-political views on national security issues clearly indicate the potential for an extraordinary diversity of threats to Ukraine's border security. For the sake of convenience, as well as the simplification of their understanding in the sense of the danger, all threats were structured according to the spheres of public life.

As a result of structuring, the following groups of threats to Ukraine's border security were identified:

1) Threats to life, health, dignity, property of citizens;

2) Threats aimed at attempting to violate the territorial integrity of Ukraine and the inviolability of the state border of Ukraine;

35 Lytvyn M. M. (2012) Intehrovane upravlinnia kordonamy [Integrated border management]. Khmelnytsky : NADPSU. (in Ukrainian). 416p. p.14.

${ }^{36}$ Babii Yu. (2016) Udoskonalennia dekompozytsii zahroz i nebezpek natsionalnii bezpetsi derzhavy u prykordonnii sferi [Improvement of decomposition of threats and dangers to the national security of the state in the border area]. Proceedings of the National Academy of State Border Guard Service of Ukraine. Series: military and technical sciences, no. 4, pp. 185-196. Khmelnytskyi. (in Ukrainian).

37 Transparency\&Oversight/Brenan Center for Justiceat NYU low.Retrieved from: https://www.brennancenter.org/issues/protect-liberty-security/transparency-oversight BB. 
3) Threats related to intelligence and subversive activity of special services of foreign states and organizations;

4) Threats related to cross-border crime;

5) Threats related to violations of the order of crossing the state border of Ukraine by persons, vehicles and cargo;

6) Information and cyber threats;

7) Threats to the economy of Ukraine, the welfare of its population;

8) Environmental threats.

Even a superficial analysis of certain groups of threats to Ukraine's border security makes it possible to conclude that their counteraction applies to all components (types) of national security, namely: military security, state security, as well as public security and order, etc.

\section{Certain features of the state mechanism functioning concerning Ukrainian border security}

International experience strongly suggests that border security issues resolution in the present context requires international integration. Thus, Anton Grisold defines that a "cooperative" model of international security must take the place of starting point for the formation of a new, more effectively adjusted structure of national and global security in our modern world $^{38}$.

Since 2005, the Organization for Security and Co-operation in Europe (OSCE) has been using the Concept of "Open and Secure Borders in a Free, Democratic and More Integrated OSCE Area without Boundaries". The Concept covers three areas of the OSCE activity like political and military, economic and environmental that prioritize counteraction to threats such as: terrorism; organized crime; trafficking in human beings; arms smuggling and drugs; corruption ${ }^{39}$.

Thus, the reliability of the functioning of the state border security mechanism of Ukraine stems directly from its ability to effectively counter the above groups of threats.

Thus, it is possible to define the basic, generalized functions of the national-level mechanism of ensuring the border security of Ukraine, namely:

implementation of the state policy in the sphere of border security of Ukraine;

\footnotetext{
${ }^{38}$ Grizold A. The concept of national security in the contemporary world.International Journalon World Peace, vol.11, no.3(September1994),pp.37-53Retrieved from:https://www.jstor.org/stable/20751984.

39 Transnational Threats Department Border Security and Management Unit Retrieved from: https://www.osce.org/resources/factsheets/border-security?download=true.
} 
carrying out law-creating activity concerning legal and regulatory framework on border security issues;

collecting information to identify real and potential threats to Ukraine's border security, the causes and prerequisites for their occurrence and possible transformations;

developing and submitting the draft budget expenditures for approval concerning the implementation of border security programs;

carrying out international cooperation in the sphere of border security;

ensuring the adoption and implementation of decisions regarding the elimination of threats to Ukraine's border security, as well as the reasons for their occurrence;

co-ordinating and managing the use of forces and facilities to eliminate threats to border security;

carrying out monitoring (control) over its own activity, implementing the measures of own and internal safety maintenance, other measures on maintenance of own reliability and viability;

performing current analysis of the existing situation, adjusting previously taken decisions, etc.

The content of the generalised functions of the nation-wide border security mechanism of Ukraine implies the availability of certain tools.

Among other tools of influence that can be used to ensure border security, the special place is occupied by the operational and investigative activity, as a system of public and private search, intelligence and counterintelligence activities carried out with the use of operational and operational-technical means ${ }^{40}$.

Operational and investigative activity, as a sphere of law enforcement activity, is regulated by the Law of Ukraine "On Operational and Investigative Activity". Thus, Article 1 of the aforementioned law separately emphasizes that the task of the operational and investigative activity is to search and record actual data on the illegal actions of individuals and groups, the responsibility for which is provided by the Criminal Code of Ukraine, intelligence and subversive activity of special services of foreign states and organizations for the purpose of termination of offenses and in the interests of criminal justice, as well as obtaining information in the interests of the security of citizens, society and the state ${ }^{41}$.

${ }^{40}$ Pro operatyvno-rozshukovu diialnist: Zakon Ukrainy vid 18.02.1992 №2135-Kh II. Data onovlennia : 02.08.18 URL: http://zakon.rada.gov.ua//laws/show/2135-12. (data zvernennia : 23.10.2018).

${ }^{41}$ Pro operatyvno-rozshukovu diialnist: Zakon Ukrainy vid 18.02.1992 №2135-Kh II. Data onovlennia : 02.08.18 URL: http://zakon.rada.gov.ua//laws/show/2135-12. (data zvernennia : 23.10.2018). 
Thus, the national legislator normatively establishes, so to speak, the threefold internal essence of the operational and investigative activity, which is conditioned by the execution of investigative, intelligence as well as counter-intelligence activities.

It is expedient to research the features of practical application of certain functions of the national border security mechanism of Ukraine on the example of the State Border Guard Service of Ukraine, which is an important component of this mechanism and implements the state policy in the sphere of the state border security.

The current stage of the State Border Guard Service of Ukraine development is accompanied by a tendency to deepen the division of spheres and types of activities, complication of organizational and staff structure, which poses additional requirements to the efficiency of coordination of different types of labour activities. This state of affairs creates new requirements for the management system, in particular for the management of the operational and investigative activities of the State Border Guard Service of Ukraine, which necessitates a careful study of the basic conceptual approaches to management.

The State Border Guard Service of Ukraine is the only law enforcement agency of the special purpose, composed of, at the same time, units that carry out intelligence, counterintelligence activities, as well as undertake operational counteraction to crime at the state border of Ukraine. The study of the peculiarities of their functioning within the structure of the State Border Guard Service of Ukraine provides an opportunity, in a way, to extrapolate the experience of the service to the system of border security ensuring as a whole.

Thus, on the basis of studying the capabilities of the available tools in the state mechanism, the measures of border security are carried out through, as well as ensuring the implementation of basic functions by the mechanism, we can conclude that a significant role in this process belongs to operational and investigative activity. Moreover, operational units play a supporting role in the implementation of some of the functions of the mechanism.

These functions include: elaborating draft budgetary expenditures for the implementation of border security programs; ensuring international cooperation in the sphere of border security; ensuring the adoption and implementation of decisions regarding the elimination of threats to Ukraine's border security, as well as the reasons for their occurrence; performing current analysis of the existing situation, adjusting of previously taken decisions, etc.

On the other hand, the units that carry out operational and investigative activity play a major role in the implementation of some of the functions of the border security mechanism. These include: collecting, storing, processing information to identify real and potential threats to Ukraine's 
border security, the causes and preconditions for their occurrence and possible transformations; monitoring of own activity and ensuring reliable functioning of the mechanism within the limits defined by the legislation of Ukraine, as well as ensuring its own and internal security; performing current analysis of the existing situation in order to adjust previously taken decisions, etc.

Thus, the bodies and units that carry out operational and investigative activity are an integral part of the mechanism of ensuring the border security of Ukraine.

\section{CONCLUSION}

Therefore, on the basis of the foregoing, the following conclusions can be drawn: the legislation of Ukraine defines the border security ensuring as one of the most important functions of the state, as well as one of the main tasks of state administration, and priorities in the activity of the state apparatus.

Currently, the mechanism for ensuring the border security of Ukraine is formed and functioning. It includes the armed forces and other security agencies, special services, as well as law enforcement agencies of Ukraine, which perform the tasks of border security, both independently and with the involvement of enterprises and organizations, as well as other legal and natural persons.

The border security mechanism in Ukraine addresses a wide range of functions and tasks in order to identify and counteract national security threats within the border sphere. It researches the reasons and facilitates the elimination of causes of their occurrence.

The State Border Guard Service of Ukraine occupies one of the key places within the state border security mechanism carrying out the direct implementation of the state policy within the sphere of the state border security and protection of Ukraine's sovereign rights in its exclusive (maritime) economic zone.

Based on the experience of the State Border Guard Service of Ukraine, the tasks performed by the operational units in the course of fulfilling the tasks of ensuring border security have been studied and analysed. The role and the place of the units carrying out the operational and investigative activity within the structure of the mechanism of ensuring the border security of Ukraine have been outlined. It has been separately stated that, depending on the nature of the functions, the operational and investigative units may play an auxiliary or a major role.

\section{SUMMARY}

The research is devoted to the study of the issues of functioning of the mechanism of security of the state border of Ukraine. It is stated that state 
border security is an integral component of Ukraine's national security as a state. Particular attention paid to the peculiarities of the operation of the operative-search component of the state mechanism of ensuring the border security of Ukraine. The study is based on the example of the State Border Guard Service of Ukraine, which is the only law enforcement agency in the country. It also includes units that carry out intelligence, counterintelligence activities, as well as operational counteraction to crime at the state border of Ukraine. The peculiarities of their functioning in the structure of the State Border Guard Service of Ukraine make it possible to extrapolate the experience on the service to the system of ensuring the border security as a whole. It also shows the role and place of the units that carry out search operations in the implementation of the border security mechanism functions.

In the course of the research, it was established that the units that carry out search operations in the implementation of certain border security functions, such as collection, storage, information processing, etc., play a major role.

\section{REFERENCES}

1. Konstytutsiia Ukrainy: Zakon Ukrainy vid 28.06.1996 № 254k/96-VR. Data onovlennia: 30.09.2016. URL: http://zakon3.rada.gov.ua/laws/main/ 254k/96-vr. (data zvernennia 23.05.2019 roku).

2. Sytnyk G. P. (2012) Derzhavne upravlinnja u sferi nacionaljnoji bezpeky (konceptualjni ta orghanizacijno-pravovi zasady) [Public administration in the field of national security (conceptual and organizational and legal bases)]. Kyiv : NADU. (in Ukrainian).

3. Tsevelov O. Ye., Zhuk S. M. (2017) Aktualni pytannia zabezpechennia prykordonnoi bezpeky Ukrainy u systemi natsionalnoi bezpeky [Topical issues of ensuring the border security of Ukraine in the national security system].Investments: practice and experience, no10,pp.88-90. (in Ukrainian).

4. Melnyk A.F., Obolenskyi Yu.A., Vasyna A.Yu. (2014) Derzhavne upravlinnia [Governance] / A.F. Melnyk (ed). Kyiv : Znannia. (in Ukrainian).

5. Lytvyn M. M. (2012) Intehrovane upravlinnia kordonamy [Integrated border management]. Khmelnytsky : NADPSU. (in Ukrainian).

6. Kuprijenko D. A. (2014) Osnovni ponjattja ta kateghoriji u sferi zabezpechennja prykordonnoji bezpeky [Basic concepts and categories in the field of border security].Collection of scientific papers of the National Academy of the State Border Guard Service of Ukraine. Series: Military and Technical Sciences, no. 1(64), pp. 357-368.(in Ukrainian). 
7. Slovnyk ukrajinsjkoji movy: Akademichnyj tlumachnyj slovnyk ukrajinsjkoji movy [Dictionary of the Ukrainian Language: Academic Interpretative Dictionary of the Ukrainian Language].Retrieved from:https://sim.in.ua.mekanizm (accessed21 May 2019). (in Ukrainian).

8. Marchenko M.N. (2014). Teoriya gosudarstva i prava[Theory of government and rights]/ V. K. Babaeva (ed.). Moskva : Yurayt. (in Russian).

9. Prytula A.M. (2019) Taktyko-pravovi zasady operatyvno-sluzhbovoi diialnosti Derzhavnoi prykordonnoi sluzhby Ukrainy : monohrafiia [Tactical and legal principles of the operational service of the State border service of Ukraine : monograph]. Odesa : Feniks. (in Ukrainian).

10. Pro natsionalnu bezpeku Ukrainy: Zakon Ukrainy vid 21.06.2018 Vidomosti Verkhovnoi Rady (VVR), 2018, № 31, st.241 URL: https://zakon.rada.gov.ua/laws/show/2469-19 (data zvernennia 18.06.2019 roku)

11. Novyi tlumachnyi slovnyk ukrainskoi movy u trokh tomakh (2008) [A new interpretative dictionary of the Ukrainian language in three volumes]. Kyiv: Akonit.Vol. 1. P. 202. (in Ukrainian).

12. Pro Natsionalnu politsiiu Ukrainy: Zakon Ukrainy vid 02.07.2015 № 580-VIII. Data onovlennia: 06.02.2018. URL: http://zakon5.rada.gov.ua/ laws/show/580-19. (data zvernennia 10.02.2019 roku)

13. Panova O.O. (2017) Informatsiine zabezpechennia publichnoi bezpeky v Ukraini [Public security information in Ukraine]. Actual problems of domestic jurisprudence, vol. 2, no.6,p.126.

14. Abroskyn V.V. (2019) Administratyvno-pravovi zasady zabezpechennia Natsionalnoiu politsiieiu Ukrainy publichnoi bezpeky $\mathrm{v}$ umovakh antyterorystychnoi operatsii : monohrafiia [Administrative and legal principles of ensuring public security in the conditions of anti-terrorist operation by the national police of ukraine: monograph]. Kharkiv: Folio. (in Ukrainian).

15. Novyi tlumachnyi slovnyk ukrainskoi movy u trokh tomakh (2008) [A new interpretative dictionary of the Ukrainian language in three volumes]. Kyiv : Akonit.Vol. 3.P.489. (in Ukrainian).

16. Conceptual frame work for development of the National security system of Ukraine(2015) Analytical report the National Institute for Strategic Studies.KyivRetrieved from:http://en.niss.gov.ua/public/File/docs/ national_security_final.pdf.

17. Vlasiuk O. S. (2016) Natsionalna bezpeka Ukrainy: evoliutsiia problem vnutrishnoi polityky [National security of Ukraine: the evolution of domestic policy issues]. Kyiv : NISD. (in Ukrainian).

18. Shchokin H. V., Holovatyi M. F., Antoniuk O. V., Sladkevych V. P. (ed.)(2007) Menedzhment [Management]. Kyiv : MAUP. (in Ukrainian).

19. Lytvyn M.M. Aktualni pytannia zabezpechennia prykordonnoi bezpeky Ukrainy v suchasnykh umovakh derzhavotvorennia [Topical issues 
of ensuring the border security of Ukraine in modern conditions of state formation] Retrieved from:https://dpsu.gov.ua , upload , file , golova_11(accessed 10 Octover 2019). (in Ukrainian).

20. Horbulin V.P., Kachynskyi A.B. (2009) Zasady natsionalnoi bezpeky Ukrainy[National security principles of Ukraine]. Kyiv : Intertekhnolohiia.P. 136. (in Ukrainian).

21. Babii Yu. (2016) Udoskonalennia dekompozytsii zahroz i nebezpek natsionalnii bezpetsi derzhavy u prykordonnii sferi [Improvement of decomposition of threats and dangers to the national security of the state in the border area]. Proceedings of the National Academy of State Border Guard Service of Ukraine. Series: military and technical sciences, no. 4, pp. 185-196. Khmelnytskyi. (in Ukrainian).

22.Transparency\&Oversight/Brenan Center for Justiceat NYU low.Retrieved from: https://www.brennancenter.org/issues/protect-libertysecurity/transparency-oversight BB.

23. Grizold A. The concept of national security in the contemporary world.International Journalon World Peace, vol.11, no.3(September1994),pp.37-53Retrieved from:https://www.jstor.org/stable/20751984.

24.Transnational Threats Department Border Security and Management Unit Retrieved from: https://www.osce.org/resources/factsheets/bordersecurity?download=true.

25. Pro operatyvno-rozshukovu diialnist: Zakon Ukrainy vid 18.02.1992 № 2135-Kh II. Data onovlennia : 02.08.18 URL: http://zakon.rada.gov.ua//laws/show/2135-12. (data zvernennia : 23.10.2018).

\section{Information about the author:} Pavlo Volynets, Candidate of Psychological Sciences, Associate Professor of Operational and Investigative Activity Management Department Bohdan Khmelnytskyi National Academy of the State Border ty Guard Service of Ukraine, 46, Shevchenka, Khmelnytskyi, Ukraine ORCID ID: orcid.org/0000-0003-0298-2346 
Publishing house "Liha-Pres"

9 Kastelivka str., Lviv, 79012, Ukraine

44 Lubicka str., Toruń, 87-100, Poland

Printed by the publishing house "Liha-Pres"

Passed for printing: November 25, 2019.

A run of 150 copies. 